University of Louisville

ThinkIR: The University of Louisville's Institutional Repository

Electronic Theses and Dissertations

$12-1982$

\title{
Charles Wilkins Short : Kentucky botanist and physician, 1794-1863.
}

Deborah Susan Skaggs 1949-

University of Louisville

Follow this and additional works at: https://ir.library.louisville.edu/etd

Part of the United States History Commons

\section{Recommended Citation}

Skaggs, Deborah Susan 1949-, "Charles Wilkins Short : Kentucky botanist and physician, 1794-1863."

(1982). Electronic Theses and Dissertations. Paper 1972.

https://doi.org/10.18297/etd/1972

This Master's Thesis is brought to you for free and open access by ThinkIR: The University of Louisville's Institutional Repository. It has been accepted for inclusion in Electronic Theses and Dissertations by an authorized administrator of ThinkIR: The University of Louisville's Institutional Repository. This title appears here courtesy of the author, who has retained all other copyrights. For more information, please contact thinkir@louisville.edu. 


\title{
CHARLES WILKINS SHORT: KENTUCKY BOTANIST \\ "AND PHYSICIAN, 1794-1863
}

\section{By}

\section{Deborah Susan Skaggs}

B.A., University of Louisville, 1970

\author{
A Thesis \\ Submitted to the Faculty of the \\ Graduate School of the University of Louisville \\ in Partial Fulfillment of the Requirements \\ for the Degree of
}

Master of Arts

Department of History

University of Louisville

Louisville, Kentucky

December, 1982 
ABSTRACT

Charles Wilkins Short (1794-1863) participated in the evolution of a scientific community in the United States. His interests in botany began when he was a student at the University of Pennsylvania (M.D. 1815). As a country doctor in western Kentucky (1817-1825), then as professor of materia medica at Transylvania University in Lexington, Kentucky (1825-1838), and the Louisville Medical Institute (later University of Louisville, 1838-1849), and finally in retirement, Short devoted himself to the classification of flora of his native state and region. In 1828 Short co-founded The Transylvania Journal of Medicine and the Associate Sciences, in which he published many of his. findings, including a catalogue of Kentucky plants. His most significant contribution to the development of American botany, however, was his extensive correspondence and distribution of plants with naturalists in his country and abroad at a time of increasing scientific specialization and the rise of the professional botanist. 
TABLE OF CONTENTS

Page

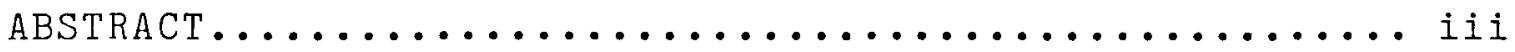
CHAPTER

I. A Philladelphia doctor $\ldots \ldots \ldots \ldots \ldots \ldots \ldots \ldots \ldots$

II. A COUNTRY DOCTOR..................... 24

III. A TRANSYLVANIA PROFESSOR............... 54

IV. A NEW HOME IN LOUISVIlle................. 100

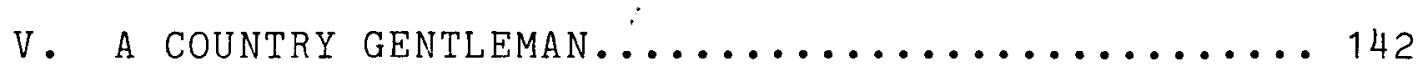

VI. THE LEGACY....................... 170

BIBLIOGRAPHY $\ldots \ldots \ldots \ldots \ldots \ldots \ldots \ldots \ldots \ldots \ldots \ldots \ldots \ldots \ldots \ldots \ldots \ldots \ldots \ldots \ldots$

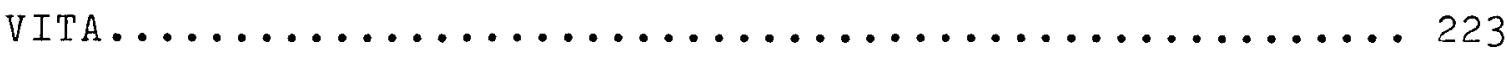


CHAPTER I

\section{A PHILADELPHIA DOCTOR}

The war was in its second year and young men were still enlisting. One Kentuckian, nineteen-year-old Charles Wilkins Short, prepared for a journey eastward, but not to join the army as did many of his Lexington acquaintances. On October 2, 1813, Charles left his home for Philadelphia, where he would attend medical classes at the University of Pennsylvania. He traveled by horseback to Limestone (now Maysville), crossed the Ohio River, and then rode to Chillicothe, Zanesville, Wheeling, and Pittsburgh, already a town of industrial importance. At Chambersburg, Pennsylvania, Charles sold his horse to a barkeeper and journeyed by stagecoach for the remainder of his trip. On October 26, he arrived in Philadelphia, shortly before classes began. 1

Charles had decided to pursue a medical career before he was graduated from Transylvania University in 1811. His Philadelphia uncle, William Short, and other family members encouraged Charles to become a physician. Since medical schools at that time generally required students to study and work with a preceptor for two or three years before beginning classes, Charles read medicine in Lexington, Kentucky, with his uncle, Dr. Frederick Ridgely, who Charles later remembered as "one of the oddest men living." A native of 
Maryland, Ridgely had been an army surgeon in the

Revolutionary War and later served with General Anthony Wayne in the Northwest Territory Indian campaign of 1794. As early as December, 1792, Ridgely had lived in Lexington, Kentucky, where he and a partner operated a pharmacy. In 1799, the Transylvania University trustees appointed the celebrated surgeon to the newly-organized Medical Department, which remained moribund until the faculty was successfully reorganized in 1817 . For two years, Charles worked in his uncle's shop, where he read medical books, prepared medicines, and observed the doctor's activities. After the declaration of war in 1812, Charles wanted to enlist, but his father objected and insisted he finish his education.2

Charles' father, Peyton Short, was a native of Virginia and a graduate of the College of William and Mary, where he had been a member of the academic honorary society, Phi Beta Kappa. The Shorts were descendants of William Short $I$, who had come to Virginia in 1635 as an indentured servant. In the relatively fluid society of seventeenth-century Virginia, Short eventually acquired an estate he called Spring Garden, in Surry County. During the colonial period, the Short family steadily increased their wealth and standing among the Virginia gentry. Charles' grandfather, William Short $V$, operated a plantation, gristmill, and a warehouse. In 1785, he married Elizabeth Skipwith, a daughter of Sir William and Elizabeth Skipwith and a great-granddaughter of Sir Grey Skipwith, a baronet and Royalist who had fled to Virginia during the 
English Civil War. As a descendant of a Royalist, Charles' grandmother tied the family to the Virginia cavalier tradition. When William short $V$ died in 1782 his sons and executors, William and Peyton, postponed the division and liquidation of the estate pending an inflated market. In 1784, William moved to France to begin a distinguished career in the foreign service. By 1787, however, Peyton had sold the bulk of. the estate without William's consent and used the money, including his brother's share, to speculate in Kentucky and Ohio land. Peyton then emigrated to Kentucky and settled in Lexington. 3

In August, 1789 , Peyton Short married Maria Symmes, a daughter of John Cleves and Anna Tuthill Symmes of North Bend, Ohio. The same year he was appointed first collector of the port of Louisville. Several months later, Short and James Wilkinson, then a Lexington merchant, became business partners, investing in Kentucky and Ohio tobacco, which they shipped to New Orleans with the expectation of a large profit. The scheme failed and left both men in financial trouble. Peyton engaged in other business activities, including the operation of several distilleries and mills, but it was his interest in land speculation that eventually brought him even greater difficulty. From 1792 to 1796, Peyton Short represented Fayette County in the Kentucky senate; in 1793 he served as president of the Transylvania Land Company, a Lexington citizen's committee that worked to secure the permanent location of Transylvania Seminary (later Transylvania University) in Lexington. 4 
About 1794 Peyton and Maria Short moved from Lexington with their two-year-old son, John Cleves, to an estate on the north fork of Clear Creek in Woodford County, within a day's ride of Lexington. Peyton first named his acreage Spring Garden, after the original Short home in Surry County, but later renamed it Greenfield. There he lived as a gentleman farmer, with slaves, cattle, and time to pursue his avocation of horse breeding. During the family's first year at Greenfield, a third son (the first, William, died in 1791) was born on October 6, 1794, and named Charles Wilkins, after the husband of Jane Short Wilkins, Peyton's sister. Four years later, a daughter, Betsey Skipwith, was born, but she died in 1800. That year another daughter, Anna Maria, was born at the estate. Years later in correspondence to his brother, Charles recalled the days of his childhood at Greenfield, where he experienced the joys of a farm boy, observed horticulture in Kentucky's fertile Bluegrass region, and read works in his father's library on farming and animal husbandry. Charles later considered buying the estate and returning to his childhood home, situated in what he called the "Garden of Kentucky, and the Eden of the West." 5 On March 28, 1801, Charles' mother, Maria Symmes Short died. The next year, probably in late spring, brothers John and Charles moved to Lexington and entered Transylvania University, which then consisted of an academy and a college. For two years, they attended classes in the academy, a preparatory department which offered basic courses in Greek, Latin, arithmetic, reading, and English 
grammar. William Leavy, also a student in the academy, recalled in his memoirs that Charles lived with his Uncle Charles Wilkins' family on the northwest corner of Second and Upper Streets. Charles later recalled spending time with the family of his Aunt Elizabeth Short Ridgely. During these early school years, the Short boys received letters of encouragement and advice from their maternal grandfather, John Cleves Symmes (1742-1814), a Revolutionary War Colonel, politician, jurist, land speculator, and colonizer in the Northwest Territory. Originally from Long Island, Symmes had moved to Sussex County, New Jersey, in 1770, where he was an officer in the militia and a county representative to the state council. From 1777 to 1783, Symmes served as an associate justice of the supreme court of New Jersey. In 1785 and the following year, he represented New Jersey in Congress. He moved west when Congress appointed him a judge in the Northwest Territory. Symmes' activities as a land speculator in ohio left him in debt, but he managed to save a tract in Ohio fronting the Ohio River and situated between the Miami and Little Miami rivers known as the Miami or Symmes Purchase. There he established North Bend. From North Bend or Washington City, Symmes wrote to his grandsons Charles and John with advice on forming their daily habits, which included writing a weekly letter to a friend or relative, for "he who can write a good letter is capable of doing other good things. 6

In November, 1802, Peyton married Jane Henry Churchill, a widow and native of New Jersey. She moved to 
Greenfield, and in 1804 her mother, Mary Henry, brought her granddaughter, Mary Henry Churchill, who was four months older than Charles, to the Kentucky estate. During the next four years, the number of children at Greenfield increased with the birth of three daughers: Jane Ann (1803-1841), Elizabeth (1804-1827), and Sarah (1806-1829). Peyton adopted Jane's daughter, Mary, although the girl continued to use the Churchill name. Charles revered his stepmother, calling her "the loveliest, kindest, and best of parents."7

By 1804 the Short boys had left the Lexington academy to continue their education at the Joshua Fry School in Mercer County, adjacent to their native Woodford. A Virginian and business associate of Peyton Short, Fry operated the private school at his farm home five miles west of Danville. Nineteenth-century historians praised the accomplishments of Fry and named Charles Wilkins Short among his outstanding students. The exact dates of the brothers' attendance at the Fry School are unclear, but in their later correspondence they did not omit references to their schoolmaster. In 1839 , Charles recalled that Fry had informed him of the death of his great-uncle Sir Peyton Skipwith in 1805 with the statement that "now Charles, all the Royal Blood of your family is extinct." 8

In 1808 Charles' stepmother died at Greenfield. The next year, Peyton Short sold the estate to Colonel Thomas Hart for about $\$ 30,000$, which nearly covered his debts to Major William Croghan of Locust Grove, Jefferson County, Kentucky, and Joshua Fry. Short also owed other debts, in 
addition to approximately $\$ 30,000$ of ohio land notes which had come due. His brothers-in-law, Dr. Frederick Ridgely and Charles Wilkins, handled these financial affairs. Ridgely and Wilkins provided the Short children with a home, except for Peyton Short's adopted daughter, Mary Henry Churchill, who in 1810 returned with her grandmother Henry and Uncle James Henry to the Geneva, New York, home of another uncle, Dr. John Henry. Mary lived in Geneva for about one year and then made her permanent home with Colonel James Henry in New Jersey. 9

At this time it was convenient for Charles to re-enter Transylvania University. In 1807 he matriculated in the four-year college program and attended classes in mathematics, including algebra, geometry, and trigonometry; English composition; classical languages; natural philosophy; astronomy; and history. Short was graduated with a bachelor's degree from Transylvania in 1811.10

Charles' childhood and adolescent association with his brother ended when he entered college in Lexington. From 1807 to 1809 , John Cleves Short studied law at Princeton University. John later returned to Lexington where he continued his legal education under Joseph Hamilton Daveiss (1774-1811), a federal district attorney for Kentucky and colonel in the western militia commanded by General William Henry Harrison. John's legal pursuits were interrupted when his preceptor died at the Battle of Tippecanoe in 1811. Although Peyton short would not give his consent for either son to enter the service when war was declared in 1812, John 
briefly served as a volunteer aid to General Harrison, who was his uncle. The general was married to Anna Symmes, a sister to the Short boys' mother, Maria Symmes. Late in 1812, John took up residence in Cincinnati, and again studied law with a local practicing attorney. 11

Charles' years at Transylvania and study with

Dr. Ridgely constituted a formative period in his educational development, daily habits, Iiterary and cultural preferences, and attraction to his step-sister, Mary Henry Churchill. While a student at Transylvania, sixteen-year-old Charles kindled his friendship and affection for Mary with letters on the activities of her Lexington girlfriends. In 1812 he wrote, "I see them seldom and have less to say to them, and when $I$ do see them it only serves to recall you, to my mind." He looked forward to attending medical school in Philadelphia, from where he would have the opportunity to visit Mary in New Jersey. To her, Charles recommended his favorite author, Sir Walter scott, and in one letter copied passages from "Lady of the Lake." Sickness plagued Charles during his studies with Ridgely, who predicted that his student would not live past twenty-five years, because of his susceptibility to lung disease. At the doctor's advice, Charles took daily walks, a habit he continued to enjoy throughout his Iife. 12

Charles' Uncle William first invited his nephew to Philadelphia to attend medical classes at the University of Pennsylvania. This bachelor uncle proved to be a dominating force in the life of Charles Wilkins Short. William Short 
had settled in Philadelphia in 1810 after his retirement from a distinguished diplomatic career. In 1799, he was graduated from the College of William and Mary with a bachelor's degree. In college William enjoyed classes in modern languages and had been a founder of Phi Beta Kappa. After graduation William stayed in Williamsburg and studied law under George Wythe, a colonial patriot, jurist, and professor of law at the College of William and Mary. In 1781, William Short was examined and certified to practice law by his preceptor Wythe and Thomas Jefferson. During his Williamsburg school days, William had become acquainted with Jefferson, then the governor of Virginia, and in 1784 accompanied him to France after the Sage of Monticello had been appointed United States minister to that country. In 1789 , Short advanced in the diplomatic ranks with his appointment as the United States chargé d'affairs in France. Three years later, Short represented his country as minister to The Hague. During the 1790s, William Short secured loans from Dutch banks and acted as a fiscal agent for the United States in Europe. In 1792, he also went to Madrid to negotiate a Spanish treaty regarding the boundary of Florida, commercial and navigational rights on the Mississippi River, and access to the port of New Orleans. He was later replaced by the South Carolinian Thomas Pinckney, who in 1795 successfully negotiated the Treaty of San Lorenzo. Short returned to France without a diplomatic assignment and courted a widow, the Dutchess de la Rochefoucauld, called Rosalie by her friends. Rosalie refused to marry William 
Short, and in 1802 he returned to the United States to oversee his financial investments in bonds, stocks, and land in Virginia, Kentucky, and western New York. The next year, he visited his brother Peyton and other family members in Kentucky. In 1808 , President Thomas Jefferson nominated Short as minister to Russia, but in 1809 the senate rejected the establishment of a mission there. During his years as an American diplomat, Short made personal financial investments which later provided working capital for retirement from government service. These included stocks, insurance companies, industries, canals, railroads, municipal bonds, and land. This prudent, cautious man showered Charles with advice and often money, being remarkably liberal with words and cash for his favorite nephew. 13

In the spring and summer of 1813, Charles and Uncle William planned a course of medical study in Philadelphia. Although Dr. Ridgely encouraged his student to matriculate in the 1812 fall session, Charles decided to remain with his preceptor another year. In response to Uncle William's advice to choose a profession prudently, Charles reassured him that he preferred medicine over law; his first choice had been farming, the unsuccessful career of his father. During the nineteenth century, it was customary for American medical students to continue training under a preceptor, who was usually a member of a medical faculty. This instruction provided clinical experience often absent in the medical curriculum: Dr. Casper Wistar, professor of anatomy at the Philadelphia medical school, was Uncle William's choice for 
Charles' preceptor, but the doctor no longer conducted a private practice. Wistar advised that Charles could easily arrange to study with another physician, but recommended that this was not always necessary for a diligent student. Uncle William advised his nephew to be in Philadelphia by mid-October for the commencement of lectures on the first of November. He arranged for Charles to live at Miss Margaret Drake's boarding house at the southeast corner of Seventh and George streets. 14

Charles had several days to adjust to his new home before starting classes at the oldest medical college in the United States. The requirements for the M.D. degree in 1812 included at least two years' study with a medical practitioner, two years' attendance at the medical school, one course of clinical lectures and demonstrations at the Pennsylvania Hospital or Almshouse, an acceptable dissertation, and successful completion of the final examination. Students purchased admission tickets from each professor for approximately $\$ 20$. Under the ticket system, which was practiced by American medical schools into the late nineteenth century, tuition was paid directly to the teaching professor. Schools assessed special fees for dissections and anatomy classes, hospital or clinical instruction, and matriculation and graduation. The preceptor's fee for private study was another additional charge. Class instruction was primarily through lectures and demonstrations during a four-month session, which usually began the first week in November and ended the first week in March. The 
University of Pennsylvania medical faculty consisted of seven departments, with two professors sharing duties in the Department of Surgery. There was no graded course of study, and first and second year students attended the same classes. 15

Like other medical schools at that time, the University of Pennsylvania offered a curriculum based on three broad.subject areas: basic sciences, theory and diagnosis, and treatment of disease. In his two years at medical school, Charles purchased admission tickets from these medical professors: John Redmon Coxe, chemistry; Casper Wistar, anatomy; Benjamin Smith Barton, theory and practice of medicine; Philip Syng Physick and John Syng Dorsey, surgery; Nathaniel Chapman, materia medica; and Thomas Chalkely James, midwifery and diseases of women and children. 16

These eminent physicians composed a faculty of national and international reputation. Casper Wistar (1761-1818), a native of Philadelphia and son of Quaker parents, received the M.D. in 1786 from the University of Edinburgh, then the recognized seat of medical learning. The senior professor's acclaimed textbook, System of Anatomy, had been published in 1811. He personally invited students to observe dissections conducted at the school's anatomical theater and encouraged them to practice dissecting to learn by experience. Short referred to the professors of surgery as "the officers of bleeding and tooth-drawing." Dr. Physick (1768-1837) was graduated from the University of Pennsylvania 
in 1785 and received the M.D. in 1792 from the University of Edinburgh. His nephew and the adjunct professor of surgery, John Syng Dorsey (1783-1818) had studied medicine under Physick and was graduated from the University of Pennsylvania with an M.D. in 1802. His Elements of Surgery was published in 1813, Charles' first year at the school. John Redmon Coxe (1773-1864) practiced in Philadelphia and was among the first physicians of that city to use the smallpox vaccination regularly. He was interested in the history of medicine and had published several medical books, including A Medical Dictionary (1808). Thomas Chalkely James (1766-1835) was graduated from the University of Pennsylvania in 1811 and studied obstetrics in England and Edinburgh. As early as 1802 , Dr. James had offered courses in obstetrics in Philadelphia. He served on the staff of the Pennsylvania Hospital from 1810 to 1832. In Philadelphia Charles probably received as fine a medical education as could be obtained in the young United States of America. 17

Many wealthy Philadelphians considered Nathaniel Chapman, the professor of materia medica, their family doctor. Author of a book on the subject he taught, and later elected the first president of American Medical Association in 1847 , Chapman specialized in a field which was the precursor of modern pharmacology. Defined by the contemporary Dr. Daniel Drake as "facts and principles which relate to the operation of various medical agents on the human body," materia medica was of particular importance to Short because of his later career. Before the use of 
synthetic drugs and the discovery of antibiotics, treatments and drugs were derived from plants and other natural materials. In Chapman's course, students studied botany, mineralogy, perhaps zoology, and the classification of treatments according to their effect on the body and disease. To supplement this course, the professor of theory and practice, Dr. Benjamin Smith Barton, taught summer classes in botany, for.which Charles enrolled in April, 1814. The professor had studied at the University of Edinburgh, was graduated from the University of Göttingen in 1789, and was a distinguished natural historian and pioneer American botanist. His Elements of Botany (1803) was the first American textbook written on that subject. 18

From 1796 to 1813, Barton had occupied the chair of materia medica at the Philadelphia school. Upon the death of Benjamin Rush, the celebrated American physician and University of Pennsylvania professor, Barton was moved to the vacant position in theory and practice of medicine. During his tenure, Barton taught supplementary courses in botany during the spring and summer sessions. When Charles attended his first such class in April, 1814, he expected "a rich repast of pleasure," but did not anticipate spending very much time on a course not required for graduation. On Saturday mornings Dr. Barton led his students on botanical field trips, which usually included an excursion to the Bartram Botanic Garden on the west bank of the Schuylkill River, about four miles below the city. The naturalist John Bartram had established the gardens around 1720 as.a 
collection of North American trees and other plants.

Explorations along the New Jersey and Pennsylvania shores of the Schuylkill were Barton's favorite botanical lesson. On October 6, 1814, his twentieth birthday, Charles recorded in his diary that he and Barton had traveled over the falls of the Schuylkill on a botanical excursion. What Charles first considered a break in his medical studies became his avocation and the source of his scientific reputation. 19

The end of the winter term signaled another new activity for Charles. Following Uncle William's advice and his own judgment, Charles became a private student of Dr. Nathaniel Chapman. The perceptor's library was an additional resource for Charles, and Chapman reviewed and quizzed the student on his final examinations for the M.D. degree. Charles' duties did not include "hammering over the mortar or melting ointments" as he had done at his uncle's shop because Chapman wrote prescriptions which were filled by an apothecary. Between his first and second school sessions, Charles also studied and reviewed anatomy, chemistry, and surgery. According to Charles, his typical day started at five o'clock in the morning. He read in his room until seven o'clock, his breakfast time. Afterwards he walked to Dr. Chapman's, where he read until mid-morning. At the almshouse or hospital Charles visited patients with the doctors, having purchased a ticket to "attend wards" at the city almshouse. At noon Charles sat for Dr. Barton's botany lecture, and at 2 P.M. returned home for an afternoon meal. He then returned to the preceptor's shop for two hours and 
later took a walk, reflecting on the day's lessons. In the late afternoon, Charles had tea and then went to his room, where he read until ten o'clock or half past, at which time he retired. 20

Charles enjoyed living in Philadelphia, although Uncle William advised him to pursue his education seriously and limit his social engagements. Uncle William introduced his nephew to a distinguished social circle and probably encouraged Charles to cultivate these acquaintances. One of Uncle William's friends and a fellow member and officer of the American Philosophical Society was John Vaughan, who resided, as did Charles, at Miss Drake's boarding house. Charles and John Vaughan remained friends in later years. Another boarding house resident included Joseph Francisco Correa da Serra, a Portuguese botanist and scholar, who in 1816 became his country's minister to the United States. During the late summer of 1814 , Correa da Serra traveled in the West, where he visited Charles' relatives. Charles also frequently called on and dined with his professors and accompanied his friends to Philadelphia restaurants, where his favorite dish was an oyster supper, a delicacy for the Kentuckian. Like other visitors or newcomers to the largest city in the United states, he toured such sites as the wax museum, the Navy Yard, the United States Mint, and Peale's Museum. He also regularly attended the theater, his favorite pastime. Philadelphia supported several theaters which employed actors and managers remembered as major contributors to the develoment of American drama. In January, 1814 , 
Charles attended the theater five times, and twice saw the British Shakesperian character actor Thomas Abthorpe Cooper as Othello. At the Chestnut Street Theater, the olympic Theater, the New Theater, and the old South Street Theater he enjoyed William Warren, the father of a famous American theater family, as Falstaff, and the comic actor William Burke Wood as Iago in othello. 21

Charles' attention to detail and his economical, efficient approach to daily living during his two years of medical school formed the basis of life-long habits. Following the advice of his grandfather symmes, Charles maintained epistolary memorandums in which he recorded the history of his correspondence. He reserved Sundays for writing letters and changed his signature from "Charles W. Short" to the briefer "C.W. Short." He attended book auctions and purchased scientific volumes on medicine and botany, in addition to works of literature and history, thereby increasing the size and value of his personal library. Carefully listing the name and price he paid for each volume and recording the retail price of each book, Charles indicated money saved through auction purchases. Books lent from his collection were recorded on a circulation list. Charles also kept account of money he spent and received from September, 1813, to May, 1815. A laundry list where he recorded the number of each article sent out for washing also illustrates his meticulous behavior. 22 While in Philadelphia, Charles continued to correspond with his stepsister, Mary Henry Churchill, and 
visited her several times at the home of her uncle and guardian, Colonel James Henry. In 1814 , he made the stagecoach journey over to Mary's Lamington, New Jersey, home at least twice, once in the early spring at the end of the school session and again in August. Mary shared Charles' interest in botany, and they enjoyed combining botanical observations and courtship in walks through the New Jersey countryside: In an August, 1814, letter to Mary, Charles enclosed a poem in which he compared her to the creeping Gualtheria, known for its beauty and fragrant taste. He entitled his composition "To Mary, with a sprig of Winter Green," and later submitted it to the Port Folio, a literary journal with a national circulation. His poem, signed with a solitary "S." to protect the privacy of the subject and author, appeared in the November, 1814, issue as Short's first published work.23

During his second year in Philadelphia, Charles dutifully completed the school's requirements for graduation. Again he purchased tickets from professors and repeated the courses he had taken the previous session. He considered writing his thesis on the diseases of his native western country, but decided instead to prepare a paper on the Juniperus Sabina, an evergreen shrub used as a stimulant, a topic which reflected his interest in botany and materia medica. At the end of the session, Charles passed his oral examinations, after which he confessed to Mary that he was "most heartily sick and tired of the idea of being a schoolboy." On April 8, 1815, about six months before hịs 
twenty-first birthday, Charles Wilkins Short was awarded the M.D. from the University of Pennsylvania School of Medicine without having met the minimum age requirement. 24 By age twenty-one Charles had formed most of the habits and predispositions that governed his later life. His family was the major influence.' Although Short sometimes disregarded Uncle Williams' dour advice, he listened respectfully to his elder relative. Although he selected medicine as a life's work, Short's first career choice had been agriculture, the only respectable pursuit for a true son of the Bluegrass. Later, when fortune permitted him to retire from medicine, Charles took up the life of a gentleman farmer. From relatives and in medical school, he learned exactitude and routine in his daily and scientific habits, virtues which served him well in later years. He had fallen in love with this stepsister, the woman with whom he would spend the remainder of his life. His favorite writer was Sir Walter scott, whose fiction idealized antebellum southern values. Like many of his western and southern brethren who sought medical careers, Short had entered the University of Pennsylvania to pursue his interests, but upon graduation returned to the West. Never did he leave Kentucky for an extended period. To the growing West, Short devoted his talents as a physician, a teacher, and a scholar. There he also expected to make his fortune. 


\section{NOTES TO CHAPTER I}

${ }^{1}$ Charles Wilkins Short to Mary Henry Churchill, August 28, 1813, Charles Wilkins Short Papers, File 84, Filson Club, Louisville, Kentucky (hereinafter SPFC); Short Journal, Lexington to Philadelphia, 1813, Thomas A. Courtenay Collection, Simpsonville, Kentucky (hereinafter Courtenay Collection); Short to Frederick Ridgely, January 1, 1815, Fields Collection, The Huntington Library, San Marino, California. For biographical information on Short see Irving Frederick Ahlquist, "Ohio Valley Culture as Reflected in the Short Family, 1790-1860" (Ph.D. dissertation, University of Illinois, 1947); T[homas] L[indley] B[radford], "Charles Wilkins Short," in American Medical Biographies, eds. Howard A. Kelly and Walter L. Burrage (Baltimore: Norman Remington Company, 1920), pp. 1048-1049; P. Albert Davies, "Charles Wilkins Short, 1794-1863: Botanist and Physician," Filson Club History Quarterly 19 (July 1945): 131-155, 208-249; Allen Johnson, et al., eds., Dictionary of American Biography, 20 vols. and 6 supplements to date (New York: Charles Scribner's Sons, 1928-1980), 17: 127-128 (hereinafter cited DAB); A[sa] G[ray], "Charles Wilkins Short," The American Journal of Science and Arts, 2d ser. 36 (July 1863): 130-132; S.D. Gross, "Obituary Notice of Charles Wilkins Short, M.D.," Proceedings of the American Philosophical Society 10 (November 1865): 171-186; and Ronald L. Stuckey, ed., Scientific Publications of Charles Wilkins Short (New York: Arno Press, 1978).

$$
{ }^{2} \text { C.W. Short, Transylvania University Certification, }
$$
April 4, 1811, File 147, SPFC; William Short to John Cleves Short and C.W. Short, April 6, 1811, Short, Harrison, and Symmes Family Papers, Library of Congress, Washington, D.C., microfilm in the Filson Club (hereinafter SHSLC); William Frederick Norwood, Medical Education in the United States before the Civil War (New York: Arno Press, 1971; originally published 1941), pp. 380-381; William G. Rothstein, American Physicians in the Nineteenth Century: From Sects to Science (Baltimore: Johns Hopkins University Press, 1972), pp. 85-87; John D. Wright, Transylvania: Tutor to the west (Lexington, Kentucky: Transylvania University, 1975), p. 78 ; Charles R. Staples, The History of Pioneer Lexington, 1776-1806 (Lexington, Kentucky: Transylvania Press, 1939), p. 320; John H. Ellis, Medicine in Kentucky (Lexington: University Press of Kentucky, 1977), p. 8; C.W. Short to Churchill, March 8, 1812, March 16, 1813, and August 28, 1813, File 84, SPFC.

3 George Green Shackelford, "William Short, Jefferson's Adopted Son, 1758-1849" (Ph.D. dissertation, University of Virginia, 1955), pp. i-x, 1-22, 494-497, 544. 
${ }^{4} \mathrm{C}$. W. Short and Mary Churchill Richardson,

"A Chronological Record of the Families of C.W.' Short and Mary Henry Churchill," 1843, 1879, pp. 4-5, SPFC; Ahlquist, "Ohio Valley Culture as Reflected in the Short Family," pp. 20-33; DAB, 20: 222-226; Robert Peter and Johanna Peter, Transylvania University: It's Origin, Rise, Decline, and Fall, Filson Club Publication Number 11 (Louisville: John P. Morton and Co., 1896), p. 45.

5C.W. Short to Samuel Younglove, April 29, 1840, File 93, SPFC; J.C. Short to C.W. Short, March 13, 1838, November 25,1842 , and February 23, 1855, SHSLC; C.W. Short to J.C. Short, October 30, 1825, December 1, 1825, and January 21 , 1844 , Charles Wilkins Short Papers, American Philosophical Society Library, Philadelphia, Pennsylvania (hereinafter SPAPS); C.W. Short to J.C. Short, May 3, 1852, Short Family Papers, Item Number 164, Cincinnati Historical Society, Cincinnati, Ohio; William Allen Richardson, Descendants of William Short, Genealogical Chart, 1931, Filson Club.

${ }^{6} \mathrm{C} . \mathrm{W}$. Short and Richardson, "A Chronological Record of the Families of C.W. Short and Mary Henry Churchill," pp. 123-125, SPFC; Wright, Transylvania, pp. 33-38; William A. Leavy, "A Memoir of Lexington and Its Vicinity with Some Notice of Many Prominent Citizens and Its Institutions of Education and Religion," ca. 1873, Special Collections, Frances Carrick Thomas Library, Transylvania University, Lexington, Kentucky; John Cleves Symmes to J.C. Short and C.W. Short, June 24, 1802, SHSLC; Peyton Short to C.W. Short and J.C. Short, May 23, 1803, SHSLC; Beverley W. Bond, The Correspondence of John Cleves Symmes (New York: The Macmillan Co., 1926), pp. 1-21; DAB, 18: 258-259.

${ }^{7}$ C.W. Short and Richardson, "A Chronological Record of the Families of C.W. Short and Mary Henry Churchill," pp. 41-44, 117-122, SPFC; P. Short to John Henry, May 26, 1808 , Charles Wilkins Short Papers, Southern Historical Collection, University of North Carolina, Chapel Hill, North Carolina (hereinafter SPSHC); C.W. Short to Churchill, August 10, 1810, File 84, SPFC.

${ }^{8}$ Ahlquist, "Ohio Valley Culture as Reflected in the Short Family," pp. 500-504; Lewis Collins and Richard H. Collins, History of Kentucky, 2 vols., 2nd ed. (Louisville: J.P. Morton \& Co., 1924; originally published 1847), 2: 625 , 687 ; J.C. Short to C.W. Short, February 28, 1839, SHSLC; C.W. Short to J.C. Short, April 20, 1839, SPAPS; Shackelford, "William Short," pp. 537-538.

${ }^{9}$ C.W. Short and Richardson, "A Chronological Record of the Families of C.W. Short and Mary Henry Churchill," pp. 41-44, 117-122, SPFC; C.W. Short to William Short, November 26, 1809, File 52, SPFC; P. Short to Henry, May 26, 1808 , SPSHC; C.W. Short to Churchill, August 10, 1810, File 84 , SPFC. 
10 Ahlquist, "Ohio Valley Culture as Reflected in the Short Family," pp. 50-54; C.W. Short, Transylvania University Certification, April 4, 1811, File 147, SPFC.

${ }^{11} \mathrm{C} . \mathrm{W}$. Short to W. Short, November 26, 1809, File 52, SPFC; Ahlquist, "Ohio Valley Culture as Reflected in the Short Family," pp. 37-47; DAB, 5; 80; 8: 348-352; C.W. Short to Churchill, March 8, 1812, November 4, 1814, File 84, SPFC.

${ }^{12} \mathrm{C} . \mathrm{W}$. Short to Churchill, August 10,1810 , March 8 , 1812, November 4, 1812, May 25, 1812, and March 16, 1813, File 84 , SPFC.

13W. Short to J.C. Short and C.W. Short, April 6, 1811, SHSLC; W. Short to C.W. Short, July 8,1813 , File 1 , SPFC; Ahlquist, "Ohio Valley Culture as Reflected in the Short Family," pp. 4-16; DAB, 10: 17-35; 14:617-620; 17 : 128-129; 20: 586-589; Shackelford, "William Short," pp. i-x, 23-45, 490-497, 501-505; C.W. Short to J.C. Short, May 14, 1846 , SHSLC.

${ }^{14} \mathrm{C}$. W. Short to W. Short, April 28, 1813, File 14, SPFC; W. Short to C.W. Short, July 8, 1813, File'1, SPFC; C.W. Short to W. Short, August 1, 1813, File 13, SPFC; DAB, 17: $127-128 ; 20: 433-434 ; \mathrm{C} . W$. Short to Churchill, November 7, 1813, File 84, SPFC; Norwood, Medical Education in the United States before the Civil War, pp. 380-381.

15 George W. Corner, Two Centuries of Medicine: A History of the School of Medicine, University of Pennsylvania (Philadelphia: J.B. Lippincott Co., 1965), p. 74; Norwood, Medical Education in the United States before the Civil War, pp. 392-395; Rothstein, American Physicians in the Nineteenth Century, pp. 88-89.

16 Rothstein, Ibid.; Norwood, Medical Education in the United States before the Civil War, pp. 396-402; C.W. Short, University of Pennsylvania Tickets of Attendance, 1813-1814 and 1814-1815, File 148, SPFC; DAB, 2: 17-18; 4: 19-20, $486-487 ; 5: 385-386 ; 9$ : $588-589 ; 14: 554-555$.

17 Joseph Carson, A History of the Medical Department of the University of Pennsylvania (Philadelphia: Lindsay and Blakiston, 1869), pp. 135-136; Casper Wistar to C.W. Short, December 14, 1813, SPAPS; C.W. Short to J.C. Short, July 1, 1814 , SHSLC.

18 Rothstein, American Physicians in the Nineteenth Century, p. 91; Corner, Two Centuries of Medicine, pp. 66-67, $80 ; \underline{D A B}, 5: 426-427$; C. W. Short, "Notes on a Course of Lectures delivered in the University of Pennsylvania by N[athaniel] Chapman, M.D. on Materia Medica, 1813-1815," Special Collections, Charles Patterson Van Pelt Library, University of Pennsylvania, Philadelphia, Pennsylvania. 
${ }^{19}$ Carson, A History of the Medical Department, p. 132; C.W. Short to J.C. Short, April 15, 1814, April 24, 1814 , SHSLC; DAB, 2: 26-28; C.W. Short, Diary of Activities in Philadelphia, 1814, Courtenay Collection.

${ }^{20}$ C.W. Short to J.C. Short, April 15, 1814, April 24, 1814, SHSLC; C.W. Short, University of Pennsylvania Tickets of Admission, 1813-1814 and 1814-1815, File 148, SPFC.

${ }^{21} \mathrm{C} . W$. Short to J.C. Short, October 8,1814 , October 17, 1814, April 15, 1814, and April 20, 1849, SHSLC; Richard Beale Davis, "The Abbe Correa in America, 1812-1820," Transactions of the American Philosophical Society 45 (May 1955): 55ff; Sara Agnes Wallace, "Letters of Jane Short Wilkins," Register of the Kentucky Historical Society, 51 (January 1953): 58-60; C.W. Short, Account of Money Received and Spent, September, 1813, to May, 1815, Courtenay Collection; C.W. Short, Diary of Activities in Philadelphia, 1814, Courtenay Collection; C.W. Short, Theater Attendance in Philadelphia, October 23, 1813, to February 8, 1815, Courtenay Collection; DAB, 4: 416-417; 19: 489; 20: $476-478$.

${ }^{22}$ C.W. Short, Epistolary Memorandums, 1813-1815, Courtenay Collection; C.W. Short to Churchill, January 17 , 1814, File 84, SPFC; C.W. Short, List of Books Bought in Philadelphia, Courtenay Collection; C.W. Short, Memorandum of Books Lent, 1814, Courtenay Collection; C.W. Short, Account of Money Received and Spent, September, 1813, to May, 1815, Courtenay Collection; C.W. Short, Memorandum of Articles Sent to be Washed, 1813-1815, Courtenay Collection.

23C.W. Short to Churchill, April 17, 1814, April 22, 1814, May 10, 1814, July 11, 1814, August 20, 1814, and November 27, 1814, File 84, SPFC; [C.W.] S[hort], "To Mary with a Sprig of Winter Green," The Port Folio (Philadelphia), 3d ser. 3 (May 1814): 520.

${ }^{24} \mathrm{C}$. W. Short, University of Pennsylvania Tickets of Attendance, 1813-1814 and 1814-1815, File 148, SPFC; C.W. Short to J.C. Short, July 1, 1814 , SHSLC; C.W. Short, "Juniperus Sabina," M.D. thesis, University of Pennsylvania, 1815, Courtenay Collection; C.W. Short to Churchill, March 9, 1815 , File 84, SPFC; Carson, A History of the Medical Department, pp. 116-119; C.W. Short to J.C. Short, April 9, 1815, SHSLC. 
CHAPTER II

\section{A COUNTRY DOCTOR}

On May 3, 1815, Charles Wilkins Short, M.D., left Philadelphia for Pittsburgh via stagecoach. Writing to Mary, he described the pastoral Pennsylvania Dutch countryside, with "fields, barns \& stables. - more comfortable than the interior" of the houses. Occasionally, he covered the rough, mountainous terrain of the Keystone state on foot, rather than risk injury in an upset coach. On May 10, Charles reached Pittsburgh, the "Birmingham of the West," where he spent several days with William Wilkins, president of the Bank of Pittsburgh and brother of his namesake and uncle, Charles Wilkins. 1

Charles likely pondered his future during the week-long journey. Should he undertake post-doctoral studies with internationally-known scholars in Paris or Edinburgh? Should he remain in the East, secure a teaching position, and enter a partnership with an established physician? Should he return to the burgeoning West, a section still celebrating Andrew Jackson's victory at New Orleans in January $1815 ?$ Should he live in the city or be a country doctor? Several medical professors supported Charles' inclination to remain in Philadelphia and practice medicine. Uncle William Short, however, encouraged Charles to follow the national trend of western migration.2 
Charles probably chose to establish a western practice with Uncle William's blessing. Family ties and sentiment drew him toward Cincinnati or Lexington, but reports indicated an abundance of physicians in both cities. Although offered the chair of materia medica at Transylvania University, Charles considered himself better-qualified to teach chemistry or natural history; furthermore, he feared that the recent organization of the school's Medical Department would prove unsuccessful, which it did. After declining a teaching appointment in Lexington, the unsure young short still headed West. 3

Charles visited onio relatives on the return trip. In Cincinnati, he called on his brother, John Cleves Short, who now preferred to be called by his middle name. Cleves had been married in June, 1814 , to a cousin, Betsey Bassett Harrison. In North Bend, Charles visited Betsey's father, General William Henry Harrison, and his wife Anna Symmes, the sister of Maria Symmes Short, Charles and Cleves' mother. The Shorts and the Harrisons encouraged Charles to locate in Cincinnati. Charles had recently inherited Hamilton County, Ohio, land from his deceased maternal grandfather, Judge John Cleves Symmes, and Cleves advised his younger brother to sell it and use the capital to set up housekeeping and a medical practice. Other family members offered glowing reports of the Queen City's advantages. Even Dr. Frederick Ridgely, who had supported the nomination of his nephew to the Transylvania University medical faculty, thought Charles should investigate the advantages of Cincinnati. 4 . 
On June 1, 1815, Charles arrived in Lexington, Kentucky, where he was reunited with relatives and hometown friends. During the summer, Charles continued to study his future. When his Uncle Ridgely's partner considered retiring, Charles expressed interest in practicing medicine with his former preceptor. If his uncle's partner remained in Lexington, Charles might establish his permanent residence in Cincinnati. Still undecided in mid-August, Charles accompanied his father on an excursion through western Kentucky. While at Hopkinsville, in Christian County, he informed his stepsister Mary that his father intended to give him land in the area. Charles described this region of Kentucky known as "the Barrens" (because of its lack of trees) as "a land of Milk and Honey," with "the most luxuriant plants of various kinds, and flowers of unnumbered dyes." 5

On September 7 , Charles returned to Lexington; the next month he left his childhood home, crossed the Allegheny Mountains, and journeyed to the New Jersey home of Colonel James Henry, on a mission that combined business and personal objectives. As a family representative, he had been commissioned by his brother to sell the New Jersey land inherited form their grandfather, John Cleves Symmes. During previous visits to the state, Charles had negotiated preliminary arrangements for the disposal of the property. Determined not to return to Kentucky alone, he also instructed Mary Henry Churchill to prepare for their wedding. 6 
Family rumors of Charles' affection for his stepsister had traveled back and forth across the mountains for several months, To Charles' surprise, his love life apparently had been the source of friendly gossip, although he had volunteered no information on the subject. Charles was especially tight-lipped about the engagement with Uncle William, a confirmed bachelor. At Pittsburgh, safely enroute to Kentucky.after his graduation from medical school, Charles had written his Philadelphia uncle for consent to wed. Uncle William wasted no time responding to his nephew's request. First, he advised Charles to postpone the wedding. Presently, he argued, Charles could not support a wife and inevitable children; consequently, an immediate marriage would jeopardize the young doctor's economic security and career. To further discourage Charles, Uncle William wrote that his nephew's submission to "puppy love" was "certainly the greatest mishap, short of infamy" that could happen to any man. 7

Despite Uncle William's earlier pleadings, Charles left Cincinnati on horseback for New Jersey in October, 1815. He kept a journal of his twenty-day journey. On October 9 , at Wheeling, Virginia (now West Virginia), he ate a "Kentucky style breakfast" of "warm cornbread \& good coffee." A week later, Charles arrived in Carlisle, Pennsylvania, the site of Dickinson College. He remained there the next day and "did some shopping, as the ladies call it." At his next stop, Reading, Pennsylvania, Charles noted the prevalence of brick houses. He then progressed to Bethlehem and Easton, 
Pennsylvania, crossed the Delaware River, and via the Brunswick turnpike reached his final destination, Lamington, Somerset County, New Jersey, on October $22,1815.8$

Before the wedding, Charles decided to dispose of the Flat Brook property, a former residence of his deceased grandfather John Cleves Symmes. Initially, the prospective buyers failed to meet the Shorts' purchase price, but Charles postponed the sale for five months, at which time they anticipated ready cash from crop and timber sales. With this business temporarily settled; Charles fulfilled the second goal of his mission, "the object for ten years past" of his heart's "warmest affection." On November 25,1815 , the Reverend Horace Galpin married Charles and Mary at the home of the bride's uncle, Colonel Henry. With the disposition of the Flat Brook property pending and the encroachment of winter's poor traveling conditions, the newlyweds remained at Mary's New Jersey home until spring. 9

In April, 1816, Charles awaited the emergence of a late spring. Impatiently, he projected a westerner's view of New Jersey in late April when he compared "the luxuriant and noble growth of our western forest" to "the stinted productions of this meager soil." With little else to occupy his time, Charles spent hours studying mid-Atlantic flora; drawing and collecting plants; listing their scientific names and geographic locations; and recording blooming dates for individual species. Influenced by the philosophy of Francis Bacon, Short and his contemporary botanists gathered facts about plants by observation, collection, description, and 
classification. Plant taxonomy was based on the system developed by Carl von Linne (or Linnaeus), an eighteenth-century Swedish botanist who classified plants according to their sexual characteristics. Through inductive reasoning, botanists gathered and exchanged facts and offered scientific generalizations about God's handiwork on earth.10

After the sale of the Flat Brook property in April, 1816, Charles and Mary prepared for their trip West. The next month the couple visited Mary's aunt, Ann Henry Graham, in New York City, where Char tes shopped for books to supplement his personal library. He bought a copy of Jacob Bigelow's Florula Bostoniensis (1814), a catalog of the flora of New England. Years later, this pioneer botanical work of description and classification served as a model for short's work in Kentucky botany. In mid-June, the shorts left the East in a "light little Jersey waggon with a pair of grey ponies" enroute for Virginia and Kentucky, their final destination. After purchasing the team, Charles had commented that "not withstanding the proverbial flippancy of th New Englanders, and their legitimate descendants--the people of Ohio [--] there never was, I am convinced, a more abandoned set of horse-jockeying cheats that this Jersey produces."11

Equipped with botanical supplies for collecting and preserving unknown plants, the couple headed home. In the West, Mary would be reunited with childhood friends and relatives. "John Cleves Short and his family, meanwhile, planned to move to their farm about twleve miles outside 
Cincinnati near North Bend, Ohio. He encouraged his younger brother to open a shop in Cinncinnati, and offered to rent Charles his house in the city. Dr. Short still had no definite plans for locating his medical practice, but the newlyweds preferred to settle in Lexington.12

At Cincinnati, Charles expected to visit Cleves, Betsey, and their infant daughter, Mary. During Charles' absence, the brothers had corresponded about the baby's poor health. A local doctor had prescribed calomel, a purgative of mercurous chloride populap during the early nineteenth century. Cleves opposed the medicine and asked his brother for a second opinion. He replied that physicians, "as well as the frivolous part of the world," were influenced by the prevailing customs of the day. Charles also recommended other less harsh remedies, which he believed should be suited to the baby's specific illness. Whether or not the baby was given calomel is uncertain but when Charles and Mary reached Cincinnati, their infant niece was dead. 13

After visiting Cincinnati, Charles and Mary returned to Lexington, the social and educational hub of the Commonwealth and noted among western cities for its cultural advantages. Years later, Charles admitted that his decision to settle in Kentucky rather than Ohio had been influenced by several factors, including the reported abundance of physicians in Ohio and his general impatience with northern and eastern people. Charles had been reared on a Kentucky farm with slaves and considered himself and his family dependent on them. His choice of Lexington, however, was not 
related to the possibility of teaching at Transylvania University. Since the founding of the Medical Department in 1799, the school had failed to graduate one student with the M.D. Although several physicians taught in the school, the Transylvania trustees had failed to organize a successful Medical Department. In November, 1815, when Charles was in New Jersey, the trustees had elected him to the chair of materia medica, but he declined the appointment as had four other physicians. In March, 1816, the trustees again appointed Short to the same chair. Dr. Ridgely, a trustee and faculty member, cautioned his nephew of the slim chance of success for this attempt to reorganize the medical faculty. Charles again declined the appointment. In 1815 and 1816 , the Lexington medical school was still inoperative while its exponents feared the establishement of a rival school in Cincinnati. Dr. Short was especially conscious of his youth and inexperience. 14

It is doubtful that charles opened a medical office in Lexington when he and Mary settled there around the first of August, 1816. Since Mary was pregnant, the Shorts probably decided to establish a temporary residence in the Bluegrass town. The next month, Charles again visited Christian County, Kentucky. With the encouragement of his father and Uncle Charles Wilkins, Dr. Short decided to move to western Kentucky and practice medicine. To finance the purchase of a sixty-acre homesite near Hopkinsville, Charles hoped to sell his property near North Bend, Ohio. 15

During his temporary residence in Lexington, Charles 
continued to collect and preserve specimens of Kentucky plants. The previous year, Dr. William Paul Crillon Barton, the nephew of Short's mentor, Benjamin Smith Barton, and his successor as professor of botany at the University of Pennsylvania, had written Charles for specimens of western plants. Professor Barton also proposed that they exchange correspondence about their botanical activities. The presence of a trained botanist in the West, with its untapped botanical resources, appealed to Dr. Barton, and eventually to others. 16

Shortly after his return to Lexington in 1816 , Charles met Thomas Nuttall at Postlethwait's tavern. A native of England, Nuttall was a botanist and ornithologist, whose scientific travels extended from the east coast of the United States to the Arkansas Territory and later the Rocky Mountains. Charles accompanied Nuttall on botanical trips in the vicinity of Lexington and Cincinnati. They collected plants and discovered the ruins of two Indian forts, one at the confluence of the Ohio and Miami Rivers and the second near Lexington. As a student in Philadelphia, Charles had learned about the latter fort from his friend, the Portuguese scientist, botanist, and diplomat, Joseph Correa da Serra, who had earlier traveled through Kentucky. In a letter to his friend, John Vaughan of Philadelphia, Charles described and sketched the remains of the fort near Lexington; his description was later published at the submission of Vaughan in the Transactions of the American Philosophical Society. Charles respected Nuttall and often referred to him as a 
leader in the early botanical exploration of the West. At Nuttall's suggestion, Charles set up an entomology collection, although with reserved enthusiasm he admitted that he probably would "never have the same pleasure in handling bugs" as he experienced "in pulling flowers." Short was not a naturalist interested in a variety of fields; he was becoming a botanist, a specialist in one scientific area. 17 .

On February 26, 1817, at Lamphear's Hotel in Lexington, Mary Churchill Short gave birth to the couple's first child, Peyton. Shortly thereafter, on May 21, 1817, the Shorts, accompanied by their Aunt Jane Wilkins and their half sister Anna, left Lexington for Harrodsburg Springs (now Harrodsburg), a resort in Mercer County. On June 6, 1817 , Charles, Mary, and their baby son, arrived in Hopkinsville and took up residence in a two-story brick house located on a tract that Charles now determined to be fifty-five acres adjacent to the town on the Little River. In a cleared grove stood the log barn, brick kitchen, and smoke house. Meadows, gardens, and timberland covered the property, which he had purchased for $\$ 4000$. Dr. Short described the area as "chiefly barrens of a level \& highly productive nature, occasionally [sic] interspersed with groves of timbers," laid with good roads, and populated with skilled workers. Incorporated in 1804, Hopkinsville was a flourishing young town well-suited for the addition of another physician. Dr. Short, moreover, was particularly interested in the "great variety of trees, shrubs \& annuals," many of which 
were unfamiliar to him. 18

Charles was not the only member of the short family to change residence in 1817 . In late autumn, Charles' brother Cleves and his wife Betsey moved from Cincinnati to their farm in Hamilton County outside the city. At the suggestion of Uncle William, they called their new home Shorthill. Thinking Cleves would be attracted to owning more property within his county of residence and with money due for his Christian County land purchases, Charles offered to sell his Hamilton County lands to his brother. The older brother declined. 19

On April 7, 1818, during the first year of Dr. Short's residence in western Kentucky, the trustees of Transylvania University unanimously elected him to the chair of materia medica, formerly held by Daniel Drake, who had resigned. This time Charles considered accepting the appointment. Often traveling twenty miles on horseback to visit patients, he found work as a country doctor both "laborious and unpleasant."20

For several months, Charles considered the position and sought advice from others regarding his removal to Lexington. He learned from his Lexington relatives that conditions there were now favorable for a profitable private medical practice. To his brother, Charles admitted his discontent with life in Christian County, but by the end of June, he sill remained undecided about the school's offer and another move. Benjamin Winslow Dudley, professor of surgery at the Transylvania Medical Department, encouraged.Charles to 
return to Lexington, where he might soon equal and eventually surpass his present income. Charles' father, Peyton, also a resident of Christian County, favored his son's return to Lexington, but disapproved of Charles' plan to sell his western Kentucky property to finance his establishment in another town. Although Charles predicted that he could reap a profit of two thousand dollars on the sale of his Christian County property, Peyton speculated that western land would continue to increase in value. Unwilling to repudiate his father's advice and reluctant to depend on an income derived solely from lecture fees and a medical practice, Charles again sought to sell his ohio land for ready cash.21

Charles also solicited advice from his medical school classmate, Dr. Edward Barton of Philadelphia. Charles and Dr. Barton had continued their friendship through correspondence. In a letter to Barton, Charles acknowledged other reservations concerning the professorship. He was not a medical scholar, only a country doctor with an eastern education and an interest in botany. Barton, however, knew his friend's modesty and assured Charles of his competence as a physician and teacher. Barton warned Charles not to allow "timidity or aversion to appearance in public" to influence his decision. Contrary to the advice of family members and friends, Charles did not accept the position at Transylvania. For the fourth time, he had declined an appointment to the school's medical faculty. 22

Dr."Short's medical practice in Hopkinsville and Christian County continued to expand, although the returns 
were neither pleasant nor lucrative. The occupation, however, offered opportunities to treat a variety of medical cases. Short's records of medical cases picture a nineteenth-century country doctor, who treated such common complaints as nausea, diarrhea, and high fever, as well as performing amputations and extracting teeth. On the morning of June 15, 1819, for example, Dr. Short was summoned to the home of Isaac Missick, who had extracted one of his inflammed testicles the previous evening. Using a razor, Missick had cut an inch incision through, the scrotum and squeezed out the testis. Missick estimated that he had lost two quarts of blood, before applying direct pressure to close the wound. The following morning Dr. Short saw the patient and described the affected area: "the scrotum was as large as an infant's head and together with the penis, which was also enlarged and tense, was dark as pale ink." The physician applied a warm poultice to this area, bled the patient, and prescribed a light diet and the use of purgatives. Missick eventually recovered. 23

Short's case records reveal inadequate medical treatments and little knowledge of disease pathology typical of the period before the discovery and use of antibiotics and synthetic drugs. Like the majority of his southern and western colleagues, Dr. Short practiced "heroic medicine" whereby he believed that an illness or disease resulted from an imbalance of the body's four humors which were blood, phlegm, black bile, and yellow bile. To alleviate humoral imbalances, the physician prescribed treatments, such as 
bleeding, blistering, or the inducement of vomiting, thereby cleansing or "purging" the body. Afterward the patient usually received a tonic and a select diet as stimulants. 24 Perennial epidemics were commonplace in the South during the early nineteenth century and Dr. Short dreaded the advent of autumn which signaled the spread of diseases throughout western Kentucky. Medical expertise tended to be based on theory rather than scientific investigation and principles, and the importance of sanitary conditions was unfounded. The Shorts' baby, eighteen-month-old Peyton, fell victim to an epidemic disease and died in August, 1818. After the loss of his only child, Charles became disheartened with his rural practice. Short revealed his despondency in a poem entitled "Enigma," which appeared the next year in the Lexington-based publication, The Western Review and Miscellaneous Magazine. "My nature's gentle, but more dreadful far," he wrote, "I have all the dangers, and the woes of war." Burdened with his frustration, disappointments, and helplessness, he confessed, "the more I practice the less confidence I have in my professional skills." 25

Charles hesitated to trouble Uncle William with the news of a country doctor. A three-year breach of correspondence had occurred between the two after Charles' marriage, which Uncle William had opposed. Around Christmas, 1818, Charles renewed communication with his Philadelphia uncle, and William promptly returned the favor of a letter from his nephew. In a typically protective manner, William 
Short voiced concern that Charles was over-qualified to practice as a "country doctor" and suggested that a Lexington medical education rather than a Philadelphia degree would have provided adequate training for a western Kentucky physician. In response, Charles acknowledged his debt to Uncle William for a Philadelphia education, but also informed him that his snobishness was unfounded. Around the same time, Uncle.William at the requst of the widow of Casper Wistar, arranged for Charles to receive a set of the University of Pennsylvania medical professor's surgical instruments. 26

The remaining years of the short family's residence in Christian County were tragically influenced by the effects of the Panic of 1819. Farm prices dropped, trade ceased, and banks recalled loans. When the Christian Bank, a state institution charted in January, 1818, closed its doors in 1820, each investor suffered monetary injury. Originally appointed to the bank's board of directors, Dr. Short declined the honor because he was a physician, not a financier. This decision may have saved him from further hardship. In June, 1819 , Charles, who was $\$ 2500$ in debt for the purchase of his house and other expenses, again sought cash from the sale of his Ohio land. In desperation, he authorized Cleves to sell the property at any price. Ironically, Charles' medical practice continued to increase, but his fee collections waned. In the summer of 1820, with no economic relief in sight, Charles contemplated a move to Cincinnati. When he could not interest a buyer in his 
Christian County property, he abandoned the idea. 27

While to Charles the life of a country doctor was frequently an onerous burden, his botanical pursuits in the Barrens helped him endure his predicament. Remembering his years there he later wrote, "In many a long and solitary ride through these natural flower-gardens, have our fatigues been lightened, and our spirits cheered by their floral beauties." Besides small scale farming, Charles diligently cultivated a fruit orchard, a gastronomical luxury in pioneer Christian County. Various botanists sought him out as a correspondent and supplier of plant specimens for their herbaria. Jacob Bigelow, professor of materia medica at the Harvard Medical School, a former student of Benjamin Smith Barton, and author of a descriptive catalog of New England plants, Florula Bostoniensis (1814), asked Dr. Short to supply information on the flowering seasons of various Kentucky plants for a comparative geographical study of flora. The New Harmony, Indiana, physician and botanist $\mathrm{Dr}$. Christoph Müller received specimens from short, as did the indefatigable and eccentric naturalist, Constantine Samuel Rafinesque. 28

Born in 1783 in Constantinople, Rafinesque had lived in Italy and France before his first voyage to the United States in 1802. Although not formally trained in botany, he was widely read in the field of natural sciences and plant taxonomy. For three years, he explored the Philadelphia environs, after which he returned to Sicily in 1805. In 1815, Rafinesque settled permanently in the United States. He went west in 1818 to seek a teaching position at 
Transylvania University. During the summer of that year, upon the recommendation of Charles' friend, Thomas Nuttall, the peripatetic naturalist Rafinesque wrote Dr. Short in Hopkinsville. 29

Upon arriving in the West, Rafinesque set out to explore the new territory. His intinerary through western Kentucky did not include Hopkinsville, however, aware of Charles' pioneer work in this region, Rafinesque asked Short to send his entire collection of dried plants and any duplicate specimens to Lexington for his perusal. Charles cordially transmitted forty-four unidentified and unclassified plants from his collection to Rafinesque, although it proved impractical to fulfill the entire request because of the size of Short's herbarium. Charles considered his correspondent a legitimate authority in the field of taxonomic botany. When Rafinesque declared twelve of the forty-four specimens new to him and the scientific world, Charles proudly announced their findings to his friend, Dr. Edward Barton. 30

Rafinesque had arrived in the West before his reputation. Barton warned his friend abut the naturalist's shortcomings. He advised his friend not to send new plants to "that maniac Rafinesque," who was "absolutely deranged" and disregarded by other botanists. Barton also reported that Mr. Correa da Serra was "apprehensive Rafinesque [would] make a new genus of himself." A year passed before Short again corresponded with Rafinesque, who in 1819 had assumed a position teaching botany and natural history at Transylvania. 
At that time, Rafinesque chided Charles for not sending him additional specimens of western Kentucky plants and solicited duplicates of Short's spring gatherings. Available sources do not indicate that Short complied with this request. By 1825, Rafinesque had fallen into disfavor with the administration of Transylvania University and had been expelled from the faculty. He unwillingly left Lexington and returned to. Philadelphia. 31

During his years as a frontier physician, Dr. Short's botanical enterprises enhanced his regional and national reputation as an authority on western and Kentucky flora. Thomas Nuttall, in his Genera of North American Plants (1818), a two-volume inventory of the country's flora, credited Dr. Short with significant botanical findings. In January, 1819, Dr. Daniel Drake, secretary of the Western Museum Society of Cincinnati, informed Dr. Short of his election to honorary membership. Regional societies, like the one in Cincinnati, often collected local specimens of flora and fauna from the members. John D. Clifford, curator of the Lexington, Kentucky Museum of Natural History, located in the Lexington Athenaeum, invited Dr. Short to supplement their natural history cabinet with specimens of "organic remains." In 1819 , the Academy of Natural Sciences of Philadelphia, founded in 1812 as a clearinghouse for professional naturalists, elected Dr. Short to membership, an honor which signified national recognition of short as a botanist. 32

Uncle William offered continual advice to bis nephew 
in Christian County, particularly on money, his career, and family matters. He advised Charles "to expend less than you make, so as to be able at the end of each year to add to your capital stock," which he believe should be one-third of a person's income. After the death of Charles and Mary's son, Peyton, in August, 1818, Mary had given birth on October 14 , 1818 , to their second child, daughter Mary Churchill Short, and on February 7, 1820, a second daughter, Anna Maria, was born. Aware of Uncle William's warning to avoid "another besetting sin, that of a too: early and overgrown family," and probably to allay the uncle's fears, Charles and Mary named their fourth child William who was born on November 1 , 1823.33

Because of the poor economic and health conditions, Charles had second thoughts regarding his residence in western Kentucky. The economic depression, furthermore, had exerted far-reaching effects on Short's career as a physician. The population of the county had decreased, with a corresponding decline in patients and fee collections. Short had finally concluded that western Kentucky was not the land of milk and honey, but the land of disease and sickness. He grew weary of the bilious fever epidemics which occurred each year during the hot, humid weather of August, september, and October. This annual autumnal outbreak could have been typhoid, yellow fever, malaria, dysentery, or some combination of these and other diseases. During the siege of 1822, a fever claimed the life of the Shorts' younger daughter, Anna Maria. The next year Short despairingly wrote 
that he was "anxious, if possible to ascertain the cause and remedies for this truly alarming disease. I have eagerly sought for and read everything I could get my hands on concerning it; but so great are the discrepancies of opinions among men who are held forth as shining lights in the medical world, so utterly at variance are there opinions as to the causes." 34

Uncle William's advice concerning Charles' career proved most beneficial. In 1823, Charles confessed to Uncle William his dissatisfaction with medical practice and residence in Hopkinsville, a community with a declining population. At the same time, he expressed hope in securing a teaching position at Transylvania. In the winter of 1823 , Charles Wilkins, a Transylvania trustee, informed his brother-in-law William Short about a vacant position in the Lexington school's medical faculty. Wilkins indicated that their nephew Charles would be a likely candidate, but based on past actions, Charles and other trustees had assumed that Short was not interested. William communicated this news to Charles and subtly urged him to accept the position, if offered. Discontent with his practice in Christian County, Charles assured Uncle william that he would accept an offer from the Transylvania trustees; furthermore, he had recently considered moving to northern New York state or Cincinnati. In retrospect, Charles regretted his decision not to settle in Cincinnati after graduation from medical school and acknowledged that his reason for choosing Kentucky was related to his partiality toward slavery. After several 
years as a slave owner, however, Charles became aware of its disadvantages and was prepared to consider life in the free states. Late in 1823, Charles Wilkins wrote William Short that their nephew's "modesty and reserve" was an unconquerable misfortune. Although Charles desired the Transylvania appointment, shyness had apparently prevented him from informing the trustees of his intentions. Dr. Daniel Drake received the appointment sought by Short.35

Charles Wilkins did not forget that his nephew wished to serve in the Medical Department of Transylvania University. In February, 1825, Wilkins, who still sat on the Transylvania board of trustees, learned about the impending resignation of Dr. Samuel Brown, professor of theory and practice of medicine; Dr. Daniel Drake had been named to occupy the chair vacated by Brown. Consequently, Wilkins nominated Charles as a candidate for the professorship of materia medica and medical botany, formerly held by Drake. Wilkins asked William Short to secure letters of recommendation for Charles from members of the University of Pennsylvania medical faculty and directed Charles to solicit letters on his behalf from other influential men. He also encouraged his nephew to campaign for the position, admitting to William that Charles deserved the appointment, but his modesty and retiring habits operated against him. This time, however, Charles actively sought the appointment and asked "the most intelligent, wealthy \& respectable inhabitants" of Hopkinsvilie to write letters in his behalf. He also maintained regular correspondence with his two uncles, who 
informed him of developments regardng the position. 36

Dr. Nathaniel Chapman, who had been Charles' private teacher and professor in Philadelphia, wrote a letter in support of his former student. Chapman endorsed Charles highly and noted that he was a "Botanist as well as an artist, delineating and coloring plants in the very best style." In 1825, Charles Caldwell, professor of the institutes of medicine and clinical practice at Transylvania, recommended Short as his second choice for the materia medica position. Caldwell recognized the advantages of an experienced, western physician for the medical faculty, but also noted $\mathrm{Dr}$. Short's relative lack of scholarly credentials. James Blythe, professor of chemistry, and Benjamin Winslow Dudley, both on the Transylvania faculty, supported Charles, the latter having married Short's sister, Anna Maria, in 1821. Daniel Drake and William Richardson, professor of obstetrics, supported another candidate for the materia medica professorship, and probably branded short an ally of Caldwell, Dudley, and Blythe. 37

When the trustees met in April, they appointed a subcomittee to consult with each nominee for the vacant position. By August, the trustees had not made an appointment. Apparently, Caldwell's first choice did not seek the position, so he threw his support to Short, who on the advice of Wilkins and Caldwell, had journeyed to Lexington in early August to visit the trustees and medical faculty. At a meeting of the faculty on August 9, 1825, Professor Caldwell offered a resolution advocating, Short's 
nomination to the chair of materia medica and medical botany. Blythe, Dudley, and Caldwell voted in favor of the resolution; Drake and Richardson were opposed. By the time Charles arrived in Lexington to politick for the job, the Transylvania trustees had confirmed his election. Short accepted the assignment. Aware that his colleagues Drs. Drake and Richardson had recently endorsed another man, Short preferred not to consider their actions as personal attacks on his moral or professional qualifications. Short's uncle, Charles Wilkins, remarked, however, that Dr. Drake "did everything that low cunning \& intrigue could do to prevent" Charles' appointment. 38

In 1825, Dr. Short ended the first phase of his medical career. He entered academic life with the practical experience of a country doctor and a prestigious Philadelphia education. As a botanist, Short had profitted from his years in western Kentucky. His extensive work in the collection and description of the local flora provided the foundation of a valuable herbarium. His contacts with eastern botanists, such as Thomas Nuttall, W.P.C. Barton, and Jacob Bigelow, enhanced his national and eventually international reputation as a specialist in the flora of Kentucky.

Charles' family continued to be a major influence in his Iife. While in Christian County, two of the Short's four children had died, leaving a daughter, Mary Churchill, and a son, william. At the advice of his father and Uncle Charles Wilkins, Charles had settled in western Kentucky, only to be disappointed in his career as a practicing physician. 
Charles was not given to quick decisions, and when he finally resolved to leave the Barrens, the long-range economic effects of the Panic of 1819 and his cautious inclinations prevented him from implementing his plan. He finally decided to remain in the West, return to the Bluegrass, practice medicine, and teach at the Transylvania University Medical Department. As a medical professor, the influence and significance of Dr. Charles Wilkins Short, physician and botanist, would soon be realized. 
NOTES TO CHAPTER II

${ }^{1}$ Charles Wilkins Short to Mary Henry Churchill, May 5, 1815, Short Papers, File 84, Filson Club, Louisville, Kentucky (hereinafter SPFC); C.W. Short to John Cleves Short, May 11, 1815, Short, Harrison, and Symmes Family Papers, Library of Congress, Washington, D.C., microfilm in the Filson Club (hereinafter SHSLC); C.W. Short to Churchill, May 12, 1815, File 13, SPFC; DAB, 20: 221-222.

${ }^{2}$ C.W. Short to J.C. Short, February 28, 1815, SHSLC; C.W. Short and Mary Churchill Short Richardson, "A Chronological Record of the Families of C.W. Short and Mary Henry Churchill," 1843, 1879, pp. 172-174, SPFC.

3C.W. Short to Frederick Ridgely, January 1, 1815 , Fields Collection, The Huntington Library, San Marino, California; C.W. Short to William Short, April 16, 1823, File 14 , SPFC.

${ }^{4}$ C.W. Short to W. Short, June 20, 1815, File 13, SPFC; Irving Frederick Ahlquist, "Ohio Valley Culture as Reflected in the Short Family, 1790-1860" (Ph.D. dissertation, University of Illinois, 1947), pp. 37-47; C.W. Short to J.C. Short, October 17, 1814, SHSLC; J.C. Short to C.W. Short, November 12, 1814 , File 135, SPFC; C.W. Short Diary of Activities in Philadelphia, October 10, 1814, Thomas A Courtenay Collection, Simpsonville, Kentucky (hereinafter Courtenay Collection); C.W. Short to J.C. Short, February 28, 1815, SHSLC. Short inherited land in Hamilton County, Ohio, from his grandfather, John Cleves Symmes. Before symmes died in 1814 , he had sold all but fifty-three and one-half acres of Charles' proposed inheritance.

${ }^{5}$ C.W. Short to Churchill, June 5,1815 , File 84 , SPFC; C.W. Short to W. Short, June 20, 1815, File 13, SPFC; C.W. Short to J.C. Short, June 22, 1815, SHSLC; Charles Wilkins to W. Short, June 6, 1815, File 53, SPFC; C.W. Short to J.C. Short, August 12,1815 , SHSLC; C.W. Short to Churchill, August 29, 1815, File 84, SPFC.

${ }^{6}$ C.W. Short to J.C. Short, May 16, 1826, SHSLC; C.W. Short to J.C. Short, September 7,1815 , SHSLC; C.W. Short to Churchill, September 4, 1815, File 84, SPFC.

${ }^{7}$ C.W. Short to Churchill, June 5,1815 , File 84 , SPFC; C.W. Short to W. Short, May 12, 1815, File 13, SPFC; W. Short to C.W. Short, June 20, 1815, File 2, SPEC.

${ }^{8}$ C.W. Short Journal of Trip from Cincinnati to New Jersey, 1815 , Courtenay Collection. 
${ }^{9}$ C.W. Short to J.C. Short, November 7 , 1815, November 25,1815 , November 28, 1815, SHSLC; Short and Richardson, "A Chronological Record of the Families of C.W. Short and Mary Henry Churchill," p. 11, SPFC.

${ }^{10}$ C.W. Short to J.C. Short, March 7, 1816, April 25, 1816 , SHSLC; George H. Daniels, American Sciences in the Age of Jackson (New York: Columbia University Press, 1968), pp. 48-53, 63-74; Nathan Reingold, ed., Science in Nineteenth Century America, A Documentary History (New York: Hill and Wang, American Century Series, 1964), p. 41; Charles Coulston Gillispie, ed., Dictionary of Scientific Biography, 16 vols. (New York: Charles Scribner's Sons; 1970-1980), 8: 374-381 (hereinafter cited DSB).

${ }^{11} \mathrm{C} . \mathrm{W}$. Short to W. Short, April 18, 1816, File 13, SPFC; DAB, 2: 257-258; C.W. Short to J.C. Short, May 22, 1816, June 8, 1816, June 18, 1816, March 7, 1816, April 27, 1816 , SHSLC.

SHSLC.

${ }^{12}$ C.W. Short to J.C. Short, June 8, 18, 1816,

13C.W. Short to J.C. Short, March 7, 1816, August 31, 1816, SHSLC; John Duffy, The Healers: The Rise of the Medical Establishment (New York: McGraw Hill, 1976), pp. 212-213; William G. Rothstein, American Physicians in the Nineteenth Century, From Sects to Science (Baltimore: Johns Hopkins University Press, 1972), pp. 49-51; C.W. Short and Richardson, "A Chronological Record of the Families of C.W. Short and Mary Henry Churchill," p. 10, SPFC. The drug calomel, or mercurous chloride, was prescribed as a laxative to purge the body. Excessive use of the drug can induce mercurial poisoning.

14 C.W. Short to J.C. Short, August 31, 1816, SHSLC; C.W. Short to J.C. Short, April 25, 1823, May 20, 1823, File 14, SPFC; George Washington Ranck, History of Lexington, Kentucky (Cincinnati: Robert Clarke \& Co., 1872), p. 285; John D. Wright, Transylvania: Tutor to the West (Lexington, Kentucky: Transylvania University, 1975), pp. 79-84; Transylvania University, Records of the Proceedings of the Trustees, vol. 2, pp. 204-207, 219-220, 274-280, Special Collections and Archives, Frances Carrick Thomas Library, Transylvania University, Lexington, Kentucky (hereinafter SCTU); Robert Peter and Johanna Peter, Transylvania University: Its Origin, Rise, Decline, and Fall, Filson Club Publication Number 11 (Louisville: John P. Morton and Co., 1896), pp. 95-96; John D. Clifford and Ridgely to C.W. Short, March 7, 13, 1816, Charles Wilkins Short Papers, Special Collections, Margaret I. King Library, University of Kentucky, Lexington, Kentucky (hereinafter SPUK); C.W. Short to W. Short, April 16, 1823, File 14, SPFC. 
of the Families of C.W. Short and Mary Henry Churchill," p. 11, SPFC; C.W. Short to J.C. Short, June 18, 18.16, August 31, 1816, September 20, 1816, SHSLC; Charles Wilkins to W. Short, October 24, 1816, December 5, 1816, File 53, SPFC; C.W. Short to J.C. Short, November 3, 1816, SHSLC.

16 $6_{\text {DAB }}, 2$ : 25-26; William P.C. Barton to C.W. Short, September 24,1815 , Botanical Correspondence, vol. 1, SPFC.

17 C.W. Short to J.C. Short, August 31,1816 , SHSLC; C.W. Short, "A Sketch of the Progress of Botany in Western America," Transylvania Journal of Medicine and the Associate Sciences, 9(April-June 1836): 334-336; C.W. Short to Asa Gray, October 3, 1856, Asa Gray Papers, Gray Herbarium Library, Harvard University, Cambridge, Massachusetts; DAB, 13: 596-597; C.W. Short, "Description of an Indian Fort in the Neighbourhood of Lexington, Kentucky," Transactions of the American Philosophical Society, n.s. 1 (1818): $310-312$.

${ }^{18} \mathrm{C} . \mathrm{W}$. Short and Richardson, "A Chronological Record of the Families of C.W. Short and Mary Henry Churchill, "pp. 11, 150-151, SPFC; C.W. Short to J.C. Short, June 8, 16, 1817, Charles Wilkins Short Papers, Southern Historical Collection, University of North Carolina, Chapel Hill, North Carolina (hereinafter SPSHC); Lewis Collins and Richard H. Collins, History of Kentucky, 2 vols., 2nd ed. (Louisville: J.P. Morton \& Co., 1924; originally published 1847), 1: 124-125; Christian County, Kentucky, Deed Book H, 1817-1818, pp. 243-245, Kentucky State Archives, Frankfort, Kentucky; C.W. Short to J.C. Short, November 24, 1818, SHSLC. In a letter to William Short dated December 21, 1818, C.W. Short claimed that his property consisted of about sixty-six acres.

${ }^{19} \mathrm{C} . \mathrm{W}$. Short and Richardson, "A Chronological Record of the Families of C.W. Short and Mary Henry Churchill," p. 142, SPFC; C.W. Short to J.C. Short, August 17, 1817, October 9, 1817, Mrs. William Reid, Jr. Collection, SPFC; C.W. Short to J.C. Short, May 29, 1818, SHSLC.

${ }^{20} \mathrm{C}$. W. Short to J.C. Short, July 18,1818 , May 2 , 1818, SHSLC; Emmet Field Horine, Daniel Drake (1785-1825), Pioneer Physician of the Midwest (Philadelphia: University of Pennsylvania Press, 1961), p. 126; Charles Humphreys, Jr. to C.W. Short, April 14, 1818, SPUK; C.W. Short, Memoranda of Letters, 1816-1863, SPFC.

${ }^{21}$ C.W. Short to J.C. Short, May 2, 1818, July 18 , 1818, SHSLC; B[enjamin] W. Dudley to C.W. Short, June 26, 1818, File 65, SPFC; DAB, 5: 478-479.

22Edward Barton to C.W. Short, June 12, 1818 , Botanical Correspondence, vol. 1, SPFC.

23 C.W. Short, Journal of Daily Occurrences, March and 
April, 1819, File 163, SPFC; C.W. Short, Records of Medical Cases Attended by Dr. Short While Practicing in the Environs of Hopkinsville, Kentucky, from 1817 to 1825, File 150, SPFC.

24 Rothstein, American Physicians in the Nineteenth Century, pp. 42-53; John Duffy, "Medical Practice in the Ante-Bellum South," Journal of Southern History, 25 (February 1959): $52-72$.

25 Duffy, "Medical Practice in the Ante-Bellum South," pp. 52-72; [Charles Wilkins] S[hort], "Enigma," The Western Review and Miscellaneous Magazine 1 (November 1819): 254-255; C.W. Short to E. Barton, October 15, 1818, File 164, SPFC.

${ }^{26} \mathrm{C} . \mathrm{W}$. Short to W. Short, December 21,1818 , File 13, SPFC; W. Short to C.W. Short, January 19, 1819, File 2, SPFC; C.W. Short to W. Short, April 20, 1819, File 13, SPFC; W. Short to J.C. Short, November 25, 1818, File 35, SPFC; C.W. Short to Mrs. Casper Wistar, April 20, 1819, letter-copy book, 1818-1822, File 164, SPFC.

27 William Henry Perrin, ed., Counties of Christian and Trigg, Kentucky (Chicago and Louisville: F.A. Battey Publishing Co., 1884), p. 210; Commonwealth of Kentucky, Acts of the General Assembly, 1817-1818, pp. 375-393; Commonwealth of Kentucky, Acts of the General Assembly, 1819-1820, pp. 908-911; C.W. Short to W. Short, February 15, 1843, File 26, SPFC; C.W. Short to J.C. Short, June 13, 1819, Reid Collection, SPFC; C.W. Short Memoranda of Letters, 1816-1863, June 29, 1819, SPFC; C.W. Short to Peyton Short, August 16, 1819, SHSLC; C.W. Short to J.C. Short, August 3, 1820, SPSHC.

${ }^{8} \mathrm{C} . \mathrm{W}$. Short, "A Sketch of the Progress of Botany in Western America," p. 346, C.W. Short to J.C. Short, May 29, 1818 , SHSLC; C.W. Short to J.C. Short, January 2, 1819, Charles Wilkins Short Papers, American Philosophical Society Library, Philadelphia, Pennsylvania (hereinafter SPAPS); C.W. Short to J.C. Short, February 2, 1818, SHSLC; Jacob Bigelow to William Croghan, January 27, 1817, Botanical

Correspondence, vol. 1, no. 17, SPFC; C.W. Short Memoranda of Letters, 1816-1863, August 28, 1819, SPFC; Constantine Samuel Rafinesque to C.W. Short, July 17, 1818, Botanical

Correspondence, vol. 1, SPFC.

29DAB, 15: 322-324; Wright, Transylvania, pp. 70-77; Rafinesque to C.W. Short, July 17, 1818, Botanical Correspondence, vol. 1, SPFC.

30 Rafinesque to C.W. Short, September 27,1818 , Botanical Correspondence, vol. 1, SPFC; C.W. Short to J.C. Short, October 8, 1818, SHSLC; C.W. Short to E. Barton, October 15, 1818, letter-copy book, 1818-1822, File 164, 
SPFC.

$31 \mathrm{E}$. Barton to C.W. Short, November 15, 1818 , Botanical Correspondence, vol. 1, SPFC; Rafinesque to C.W. Short, November 20, 1819, December 21, 1819, February 1, 1822, Botanical Correspondence, vol. 1, SPFC.

${ }^{32} \mathrm{C} . \mathrm{W}$. Short to Daniel Drake, January 6,1819 , letter-copy book, 1818-1822, File 164, SPFC; Thomas Nuttall, The Genera of North American Plants, and a Catalogue of the Species, to the Year 1817, 2 vols. (Philadelphia: D. Heartt, 1818), 1: 187-188; Clifford to C.W. Short, February 26, 1819, Botanical Correspondence, vol. 1, SPFC; Reuben Haines to C.W. Short, n.d., Botanical Correspondence, vol. 1, SPFC; John C. Greene, "Science, Learning, and Utility," in The Pursuit of Knowledge in the Early American Republic, eds. Alexandra Oleson and Sanborn C. Brown (Baltimore: The Johns Hopkins University Press, 1976), pp. 3-8.

33W. Short to C.W. Short, February 1, 1821, File 2, SPFC; C.W. Short and Richardson, "A Chronological Record of the Families of C.W. Short and Mary Henry Churchill," pp. 11, 25-25, SPFC.

$34 \mathrm{C}$. W. Short to W. Short, April 16, 1823, File 14 , SPFC; C.W. Short to J.C. Short, October 10, 1824 , November 14, 1822, SPAPS; John Duffy, Epidemics in Colonial America (Baton Rouge: Louisiana State University Press, 1971; originally published, 1953), pp. 138-163, 220-222; Rothstein, American Physicians in the Nineteenth Century, pp. 56-57; C.W. Short to J.C. Short, December 21, 1823, SPSHC.

35W. Short to C.W. Short, March 18, 1823, File 2, SPFC; C.W. Short to W. Short, April 16, 1823, April 25, May 20,1823 , File 14, SPFC; W. Short to Wilkins, May 14, 1823, September 20, 1823, File 56, SPFC; Wilkins to W. Short, August 21, 1823, November 15, 1823, File 55, SPFC.

36 Wilkins to W. Short, February 15, 1825, File 55, SPFC; DAB, 3: 152-153; Wilkins to C.W. Short, February 15, 1825, SPSHC; C.W. Short to W. Short, April 27, 1825, File 14, SPFC.

37 Nathaniel Chapman to Charles Caldwe11, March 3, 1825, File 66, SPFC; Caldwell to Transylvania University Board of Trustees, Lunger Collection, SCTU; DAB, 3: 406; Wilkins to C.W. Short, April 5, 1825, August 1, 1825, File 57, SPFC; Transylvania University, Medical Department Meeting Minutes, August 1, 1825, vol. 1, pp. 19-20, SCTU; W. Macbean to C.W. Short, n.d., SPUK.

38 Wilkins to C.W. Short, April 5, 1825, File 57 , SPFC; C.W. Short to W. Short, April 27, 1825, File 14, SPFC; Wilkins to C.W. Short, August 1, 1825, File 57, SPFC; Transylvania University, Medical Department Meeting Minutes, 
August 9, 1825, vol. 1, pp. 19-20, SCTU; W. Macbean to C.W. Short, n.d., SPUK; C.W. Short to W. Short, August 24, 1825, File 2, SPFC; Wilkins to J.C. Short, August 23, 1825, File 57 , SPFC. 
CHAPTER III

\section{A TRANSYLVANIA PROFESSOR}

After eight years as a country doctor, thirty-oneyear old Charles Wilkins Short accepted a professorship in the Medical Department of Transylvania University. He welcomed the prestigious appointment and his return to the Bluegrass region, where he would be reunited with relatives and friends, enjoy the cultural advantages of Lexington, and continue his botanical explorations of the commonwealth. Most importantly, however, Charles expected his new position to bolster his financial status. The next thirteen years in Lexington constituted his most active and productive period. Besides teaching, Dr. Short served as dean of the medical faculty and edited and contributed articles to the school's medical journal. His indefatigable botanical work brought him national as well as international acclaim as a specialist on Kentucky flora.

The months of August, September, and October, 1825, were busy and distressing for the newly-elected medical professor. In late August Dr. Short had arrived in Lexington to learn that he had received only a temporary appointment because the trustees had filled the vacant position so late in the year; he and possibly other nominees would be considered the next spring for the position in materia medica and medical botany. Short feared that those 
who had earlier opposed his election might nominate other physicians. With his temporary appointment confirmed and only two months before classes started, Charles set out for Hopkinsville to prepare for his new position in Lexington. He traveled north and visited his brother in ohio. From Cincinnati, Charles took passage on the Phoebus to Henderson, Kentucky, and on September 6 , he finally reached Hopkinsville on horseback. At Madisonville, Charles had learned that his father, who also lived in Christian county, had died on August 18,1825 .?

For several years Charles dealt with the settlement of his father's estate. After emmigrating to the West, Peyton Short had engaged in extensive land speculation, where he had bought real estate on credit at high interest rates and borrowed money to meet the payments. Eventually, he had secured loans from his brother william, as well as other persons, to pay his debts. Charles encouraged his uncle to sue the estate to recover a portion of his money before other creditors did Iikewise. In May, 1826, William Short won a plea of debt for approximately $\$ 21,000$ in the United States District Court against the heirs of Peyton Short.2

The disposition of Peyton's nineteen slaves presented a difficult situation for Charles and Uncle William. Four slaves were given to a creditor who agreed to cancel Peyton's debt to him. As Peyton had directed, his slave Joe, who had come west with him, received his freedom. In mid-August, 1826, Peyton Short's property was sold at 
public auction. Charles, who was sympathetic with the family slaves's fear of being sold to owners of sugar or cotton plantations in the lower South purchased one woman and her two youngest children for $\$ 750$. Uncle William had also expressed concern for their welfare and safety, and consequently bought the remaining slaves. William, who was a member and patron of the American Colonization Society, had intended to emancipate the slaves, but Charles argued that they were better off with a humane owner than in freedom. In deference to his nephew, Uncle William asked Charles to oversee the slaves and find jobs for those who were not living with members of the Short family. Joe, a free man, and his slave family continued to live with Dr. Short as they had since 1817.3

Troubled with his father's estate, Charles began his new career as a medical professor. In mid-October, 1825, he moved to Lexington, where he Iived at Mrs. Keen's boarding house. Several factors determined the postponement of the family's move: he was unable to dispose of his Christian County property and relocate in Lexington by the beginning of the winter session and Mary was pregnant, which probably was the primary reason for the family to remain in western Kentucky. If the Transylvania trustees reappointed Charles to the medical faculty, the Short family planned to move to Lexington the following spring or summer. 4

Horace Holley was president of Transylvania when Dr. Short joined the medical faculty. He taught in the Academic Department, which he considered the backbone of a 
comprehensive university; furthermore, he vigorously supported the growth and development of the Law and Medical Departments. Since his appointment to the presidency in December, 1818, Holley had favored the school's position as the major state institution of higher education in Kentucky and the West. The Virginia legislature had chartered Transylvania as a public school in 1780 and eventually the Kentucky General. Assembly watched over the administration of the school, revised its charter, and advanced it monetary appropriations, although not: on a regular or continuing basis. Holley and other Transylvania administrators realized that the commonwealth's political environment affected the success of the school and they urged the state to increase the school's funding. 5

Since his arrival in 1818 from Boston, Horace Holley, a Unitarian minister, found himself as well as Transylvania a target in a struggle between conservative Protestants, who advocated religious orthodoxy and had traditionally controlled the school, and liberal eighteencentury rationalists, such as Holley and the school's trustees. Dr. Short wisely warned that the success of the university would be assured if it avoided "the blighting influence of political partyism and religious fanaticism." Assaults from the state's political leaders, however, finally led to Holley's resignation in December, 1825. The Transylvania trustees accepted his resignation, but asked him to delay his departure. He complied and left Lexington in the spring of 1827 . Shortly thereafter, Holley 
contracted yellow fever and died on the last day of July. 6

Amid these political events, medical classes started at Transylvania as scheduled on the first Monday in November, 1825. The medical faculty consisted of Daniel Drake, dean and professor of theory and practice; Benjamin Winslow Dudley, anatomy and surgery; Charles Caldwell, institutes of medicine and clinical practice; William Richardson, obstetrics and diseases of women and children; James Blythe, chemistry and pharmacy; and Charles Wilkins Short, materia medica and medical botany. The Medical Department boasted a circulating library of almost 3,000 volumes and an anatomical museum of European-crafted wax figures. Noting Dr. Short's late appointment to the medical faculty, the editor of the Lexington-based Kentucky Reporter referred to the new professor's experience as a physician and his reputation as a "polished gentleman."7

His late appointment to the faculty, the death of his father, and his subsequent move to Lexington left Charles little time to devote to class preparations. Ten years after his graduation from medical school, Charles reentered academic Iife; this time, however, his assignment was to prepare and deliver lectures rather than isten and take notes. Typically serious and conscientious, short referred to his new job and career as "the most eventful period of my life." Characteristic of his methodical manner and shy nature, he wrote his lectures and read them to the class, which became one of his teaching traits. A selfconscious lecturer, Charles was plagued by a "naturally 
weak" voice. After three weeks at Transylvania, he confessed to Uncle William that his teaching needed improvement. 8

Although Charles enjoyed living in the Bluegrass region and strolling through familiar Lexington neighborhoods, he was lonely. On December 7, 1825, his wife Mary gave birth to another daughter, Jane. During the school's brief Christmas holiday, Charles probably remained in Lexington. To Mary he described himself as "low-spirited and good-for-nothing" and understandably complained that he was "tired to death of reading and writing about physick." Charles promised Mary that he would "love, cherish, and respect" her more than ever before. 9

Despite Charles' loneliness and discontent, he sought a permanent appointment to the Transylvania medical faculty. Overall, he had proved himself a capable teacher and found favor with his students and most of his colleagues. Transylvania trustee Charles Wilkins, again sought his nephew's re-election to the faculty. At his suggestion, William Short agreed to will a portion of his rare book collection to the Transylvania University library, if Charles remained a medical professor there. Perhaps this intended donation influenced the board members. Confident that he would be rehired, Charles returned to Christian County at the end of the school session in March. On April 3, 1826, Dr. Short was unanimously elected to the permanent chair of materia medica and medical botany; his opponents either kept quiet or changed their minds.10 
That spring Charles prepared for the family's move to Lexington. He called in outstanding patient fees, sold household furniture, and rented his Christian County property when he failed to secure a price at least equivalent to his investment. To conform to Lexington's higher standard of living and accommodate his status as a college professor and physician, Charles purchased new furniture from Philadelphia, rather than pay higher prices charged by Lexington merchants. Uncle William handled Charles' order, which included sixty yards of ingrain carpeting, two hearth rugs, tumblers, candlesticks, lamps, and a china teaset. The family had planned to leave Hopkinsville in June or early July, but when Charles became ill he had to delay their departure. After an eleven-day journey by private carriage, Charles, Mary, and their children, Mary, William, and Jane, arrived in Lexington on August 2, 1826.11

After ten years Mary and Charles had returned to a Lexington home. Prior to the war of 1812 , Lexington had been one of the largest and wealthiest cities in the west. The economic depression, which followed the war and subsequent panic of 1819 , in addition to the city's inland and landlocked geographical location, crippled Lexington's economic growth and challenged her primary position among western cities. By 1830, Cincinnati and Louisville, both strategically located on the Ohio River, surpassed Lexington in commercial prominence. During the $1820 \mathrm{~s}$ Lexington struggled with the effects of a depressed economy. The 
city, however, remained the region's cultural center. Lexington claimed Transylvania University with its Law and Medical Departments and distinguished faculties. The city also boasted the resident talents of other educators, scientists, lawyers, journalists, ministers, painters, architects, and musicians. 12

In Lexington, the Shorts took up temporary residence with their relatives, the family of Dr. Benjamin Winslow Dudley, who had married Charles' sister, Anna Maria. Charles' residential choice provided a topic for family counsel; he could usually expect advice on his personal decisions from various relatives. Uncle William advised his nephew to rent rather than buy a house in Lexington, where property value continued to decline as a result of the community's slow economic recovery. Uncle Charles Wilkins and brother-in-law Dudley, however, argued that a local physician and medical professor should have a permanent residence. That summer, Charles asked his brother and Uncle William for loans. By October, Charles had paid $\$ 1100$ toward the purchase of a $\$ 3200$ house and shop on the corner of Second and Upper Streets, which was across from his Uncle Wilkins' house and near the university's medical buildings. Dr. Short again practiced medicine and as was the custom, he advertised his professional services in the local newspapers. 13

Several months after moving into his Lexington house, Charles sought other accommodations for the slaves, who occupied the "under rooms" of the dwelling. Besides 
Ursula and her two children, Joe and his family had come to Lexington with the Shorts. With the consent of his brother Cleves and Uncle William, Charles proposed that Joe, who was a free man, and wife Rachael, a slave who belonged to Uncle William, live with Cleves in Ohio. Charles admitted his dislike of hiring out slaves. Furthermore, he opposed boarding them and free Negroes together because he paid Joe wages, while the slaves received no pay. Dr. Short argued that at Shorthill, Joe would be another farm hand and isolated from "idle, free negroes, the worst bane of our society." The couple's son, Charles, and daughter, Anna, could remain with the Shorts in Lexington. All parties agreed to the plan. 14

Dr. Short also prepared for the upcoming medical school session. During the first week of the term, each faculty member delivered an opening or introductory address on a general topic to the medical students, professors, and people of the community. Charles claimed to be preoccupied with arrangements for his new house, so he asked his brother, a lawyer by training who at that time held a seat in the Ohio legislature, to prepare his lecture. Charles preferred writing "lectures of the purely didactic and practical part" of his profession and presumed that the address would be easier for Cleves to compose. Evidently, his brother paid him the favor and received a copy of André Michaux's North American Forest Trees for his efforts while Dr. Short took pleasure in delivering it. 15 Although Charles claimed that he was too busy to 
prepare his introductory address, he did write an essay on cisterns, which were common in Hopkinsville but not used in Lexington. He delivered the paper at a meeting of the Kentucky Institute, a local literary-scientific society Dr. Short had recently joined. The organization, whose raison d'etre was the "dissemination of useful knowledge," held dinner meetings at members' homes, which led Charles to speculate that another attraction for active participation was a good supper. 16

After a week of introductory lectures, the medical school classes began. In December, 1826 , Short reported only 185 students in attendance, almost 100 fewer matriculants than the previous year. Some argued that the establishment and competition of medical schools in Cincinnati and Charleston, South Carolina, had affected Transylvania's enrollment. Dr. Short did not deny that competition existed but he contended that the depressed economic conditions of the West, the home of the majority of the school's students, and the decline of cotton prices in the South, were the primary causes for the decrease in student enrollment. According to Short, in 1826, the number of students from Louisiana, Mississippi, Alabama, and Tennessee declined by one-half from the previous year. Owing debts to his brother and Uncle William, and afraid that the success of the school was in question, Charles was disappointed with the low enrollment because faculty salaries were derived solely from student fees. 17 The medical faculty from the previous session 
returned in November, 1826. In a letter to Uncle William, Charles gave his impressions of the professional qualities of his colleagues. He called Dudley "a very excellent anatomist and a capital operator," with a "pleasant, agreeable manner." Short credited Drs. Blythe and Richardson with being reliable teachers, but suspected that Dr. Caldwell, though a noted medical theorist, had not distinguishẹd himself as a practioner. He recognized Dr. Drake's ability and reputation as a professor and physician; however, in 1827, when Drake: resigned from Transylvania and returned to Cincinnati, Short described his former colleague as "a man of very considerable acquirements," but added that there were "some unpleasant traits in his character" which "scarcely were atoned for by the redeeming excellence of his virtues--he never brought with him any number of pupils from Ohio." About himself, Charles reported that he was in better voice and could be heard by all students in the lecture room. 18

Professor Short's classes in materia medica and medical botany met daily except Sundays. He outlined the course with class lectures on four general topics: general stimulants, such as narcotics, tonics and astringents; local stimulants; chemical remedies, such as refrigerants and antacids; and mechanical remedies, such as mineral water, diluents, and emollients. On local stimulants, Short recommended the use of a cold bath after exercise, evidently an opinion contrary to common practice. He warned, however, that a cold bath could be fatal to a baby; an infant should 
be sponged rather than put into water. He probably drew examples from his practical experiences as a country doctor. Dr. Short, for example, was familiar with the symptoms of a "malignant form of intermittent fever," which was probably malaria, and its successful treatment with quinine. In 1826, Drs. Dudley and Short had visited the ailing Kentucky portrait artist Matthew Harris Jouett. Short had recognized the symptoms of the disease which he had frequently treated in Christian County and had recommended the use of quinine. Dudley had refused to prescribe a drug he had never used and Jouet died shortly thereafter. 19

At the end of the $1826-1827$ school session, the medical faculty met in the library room, where on the nomination of Dean Drake, they unanimously elected Professor Short dean for the next term. Dr. Short accepted the position, one he held for the next ten years, which was a tribute to his impartial, competent leadership and his colleagues' admiration. Upon his unanimous re-election to the deanship in 1829, for example, the medical professors commended his fairness in the execution of his duties as the administrative officer of the medical faculty, and agreed to pay him twenty dollars in appreciation of his hard work. 20

When the regular medical school session opened on the first Monday in November, 1827, the members of the Transylvania Board of Trustees were still seeking a replacement for President Holley. Despite the lack of a chief administrator and low enrollments in the academic department, the medical school retained its national and 
particularly sectional reputation, largely attributed to the faculty's control of its operation. 21

For practical and political reasons, the medical faculty recognized their need for better accommodations. To finance a new medical building, the professors solicited the aid of Lexington citizens and together formed a joint-stock company. A Medical Hall, built in 1827 at a cost of about $\$ 8000$ and occupied during the 1827-1828 academic year, was located on the northwest corner of Church and Market Streets, two blocks from the:main campus. The upper level of the structure held two lecture rooms, a janitor's room, and a library, which contained a collection of European medical books purchased in 1821 by the school's representative, Charles Caldwell. Chemistry classes met in the lecture room and laboratory on the lower level. Professor Dudley paid about $\$ 4000$ for the construction of an anatomical ampitheatre, which was a separate building located next to the Medical Hall.22

During the 1827-1828 session, the Medical Department exhibited its prosperity with the construction of new buildings, the establishment of a journal, and the attraction of additional students and a nationallyrecognized medical theorist. In February, 1828, Dean Short reported an enrollment of 152 students from Kentucky, Tennessee, Virginia, South Carolina, North Carolina, Alabama, Georgia, Louisiana, Missouri, and Maryland. At the March commencement fifty-one students received the M.D. degree. These students did not receive instruction from the 
distinguished professor Daniel Drake, who had resigned and returned to Cincinnati. Drake's replacement was John Esten Cooke, a practioner from Winchester, Virginia, and frequent contributor to medical journals, who was well received by both faculty and students and appreciated for his academic, clinical, and teaching abilities. Dr. Short commented that Cooke was a better professor and physician than the former occupant of. the chair of theory and practice. During his first session at Transylvania, Dr. Cooke published the first volume of his Treatise on Pathology and Therapeutics, a book that won national acclaim as a text.23

In December, 1827, the Transylvania Medical Department issued a prospectus of a forthcoming journal, to be edited by Professors Cooke and Short. The publication of this journal, like the construction of the medical building, had been planned by the faculty and foreseen as a stimulus to the success of the school. The Transylvania Journal of Medicine and the Associated Sciences would be published quarterly, "printed with a new type and on the best paper" that was available in the West, and be devoted to the medicine, botany, mineralogy, geology, and zoology of the southern and western states. Medical journals of Southern origin frequently included varied scientific essays of ancillary interests to physicians and persons interested in natural history. According to Short, few western physicians subscribed to eastern journals, and he predicted that few Easterners would order the Transylvania Journal, except those curious to inspect "a Western Backwood Journal." In 
the prospectus, the editors invited Transylvania alumni and their fellow western physicians to contribute to the journal's communications rather than patronize eastern journals. 24

Eastern reaction to the Transylvania Journal was less than positive and illustrated the medical sectionalism and rivalry of the day. A review in The American Medical Recorder, a. Philadelphia-based periodical, critized the role and scope of the western journal. At that time, physicians sought a national identity as a professional group. They organized community medical societies, founded and taught in medical schools, and wrote and published medical literature to improve professional standards and promote medical science. To eastern physicians, their publications represented a nationally-based profession and they contended that a western journal with a sectional focus would hamper the progress of medicine and their work to foster national unity. The reviewer also questioned the validity of an in-house publication and the medical reputation of the Transylvania editors. Dr. Cooke, at least, had contributed to medical publications, but of Dr. Short, "we have no personal knowledge," observed the writer. 25

In the third issue of the journal, editors Cooke and Short responded to The American Medical Recorder review. They expressed their disappointment in the journal's eastern reception and defended their publication. Again, they argued that they treated diseases peculiar to the West and South. The journal, they asserted, was not a vehicle for 
the promotion of professors' medical theories, but a forum whereby the school's professors and other physicians could communicate their medical discoveries, which could be scrutinized by all.26

In November, 1828, Short began his third session at Transylvania. He shouldered the duties of dean of the medical faculty and co-editor of the school's journal, even though he came to the later position with no scientific or medical publications to his credit. The Transylvania Journal of Medicine and the Associate Sciences became the outlet for the majority of his writings. From 1828 to 1839 , the school published the periodical, of which Dr. Short credited the first four volumes from 1828 to 1831 .

As editor of the journal, Short occasionally reported deaths of physicians and friends of science. In the journal's first issue, he published his obituary of his uncle, preceptor, and Transylvania medical professor, Frederick Ridgely, who had died on November 21,1824 . In another issue, Dr. Short wrote an obituary of his friend, David Meade, a former Revolutionary War officer, who had died on March 9, 1829, at his home, Chaumiere des Prairies, an estate in Jessamine County about nine miles outside Lexington. In a tribute to this family friend, short called Meade "a practical cultivator of Botany," who adorned his gardens with western flora. 27

Like other medical professors and area physicians, Dr. Short contributed, although infrequently, to the journal's medical case reports. In the February, 1830, 
issue, for example, Professor Short reported a "Case of Spontaneous Combustion of the Human Body," a common medical subject among early nineteenth-century physicians. Short told the story of a sixty-five or seventy-year-old Lexingtonian who had overindulged in drinking corn whiskey. On November 15, 1829, the old woman left her house and returned intoxicated. Later that evening, a neighbor smelled a peculiar odor, "as that of burning meat." The next morning, the neighbor decided to check on the woman, found the house filled with smoke, and the woman's charred remains on the hearth. Dr. Short deduced that the woman's body had exploded due to spontaneous combustion; more likely, however, the drunk woman had sat too near the fire and accidently burned to death. 28

Several articles by $\mathrm{Dr}$. Short reveal his relationship with his students. In his valedictory address to the 1828 graduating class, Professor Short challenged the young medicos to discharge faithfully their duties as physicians while upholding professional unity and harmony. One student, in particular, found favor with Dr. Short and together they published an article in the Transylvania Journal. In 1831, Hezekiah Hulbert Eaton, the son of Amos Eaton, a nationally-recognized educator, scientist, and author of Manual of Botany for the Northern States (1817), enrolled in the Medical Department. Apparently, Eaton was one of the few Transylvania students Short accepted for private studies, although the professor claimed that over the years he had been a preceptor to more than thirty 
aspiring physicians. Short believed that private students were more trouble than they were worth, because they regularly failed to pay him. This was not Short's attitude toward young Eaton, who he considered a diligent student and friend. When Eaton died unexpectedly on August 16, 1832, Dr. Short lost a botanical companion and one of the few local persons also skilled in botany. The professor paid tribute to his young colleague in his 1832 introductory address to the medical class, which was later published in the Transylvania Journal. 29 :

Dr. Short's writings were not limited to scholarly essays in the school journal. It was typical for the medical school dean to prepare and supervise the publication of annual school announcements to inform prospective students about the department, faculty, accommodations, and activities. In July, 1829, Dean Short issued a medical school Extra, which he wrote primarily to reaffirm the existence of the Medical Department. On May 9, 1829, fire had razed Transylvania's Morrison Hall, an Academic Department building, which was located two blocks from the Medical Department structures. Several weeks after the fire, Transylvania professor Charles Caldwell, then in Philadelphia, wrote that local newspapers had reported the destruction of the Transylvania Medical Department buildings. "I tell you they hate us here, as the Devil does holy water," observed Caldwell. He advised the dean to counteract this eastern misrepresentation with a notice in the school journal.30 
For several years, however, many observers had questioned the success of the university. From the time of Horace Holley's departure in 1827 until September, 1828, Transylvania operated without a president. Fearing his nephew had joined a "sinking ship," Uncle William blamed the university trustees, whom he likened to a "parcel of school boys," for their procrastination in hiring another administrator. The Academic Department, which had flourished under the guidance of Holley, declined in enrollment and status, whereas the Medical Department prospered under the effective leadership of an aggressive faculty. On February 8, 1828, the trustees elected Alva Woods, president pro tem of Brown University, as president. He accepted and took office in September, 1828.31

By the spring of 1829 , the health of the school appeared more favorable. Transylvania University had begun the 1829-1830 academic year with a new president, plans to rebuild Morrison Hall, and high enrollments. The next year, however, was not so promising. Although the medical school enjoyed success and held its prestigious position in the South and West, the Academic Department suffererd a setback, despite the construction of a new building. Writing to Uncle William in December, 1830, Charles expressed disappointment in President Woods, who later resigned in the spring of 1831 to become president of the University of Alabama. It was a decision which, according to Dr. Short, pleased many Transylvanians. 32 During Dr. Short's tenure at Transylvania, the 
trustees were not successful in securing and keeping a president. After Woods' resignation, three faculty members, including Short, served a time as president pro tem. In December, 1832, the trustees appointed a Lexington educator, Benjamin Orr Peers, as acting president and professor of moral and intellectual philosophy. In February, 1834, the board fired him. In July of the next year, the trustees elected an Episcopal minister, Thomas Coit, president. Coit held the position until September, 1837. While Dr. Short taught at Transylvania and served as dean of the medical faculty, acting presidents, for the most part, were responsible for the university's daily administration. The Academic Department probably suffered more from this arrangement. The Medical Department, with a separate financial and physical status, prospered and held its national reputation. 33

In 1831, meanwhile, Dean Short issued a new Medical Department announcement. The faculty remained unchanged except for the appointment of Lunsford Pitts Yandell, an 1825 medical graduate of the University of Maryland and a Tennessee physician, to the chair of chemistry and pharmacy, which had been vacated by Professor Blythe. Professor Short was the only native Kentuckian on the medical faculty. According to the announcement, a student could purchase tickets from the professors to attend lectures. The cost of the lecture and library tickets plus the matriculation fee was $\$ 110$. Requirements for graduation included two years of classes at Transylvania, with a provision that practioners 
with four years experience could attend only one year. The library, which remained open until ten o'clock in the evening, except Sundays, held approximatley 3,000 volumes, soon to be supplemented with a collection of books purchased in Europe that summer by Dr. Dudley. For about $\$ 50$ a student could study privately with a medical professor. Students were encouraged to attend the weekly meetings of the Lexingtọ Medical Society and accompany the professors, who were consulting physicians, on rounds at the Lunatic Asylum of Kentucky in Lexington. In December, 1831, Dean Short reported an enrollment of 214 students, despite competition from the reorganized Medical College of Ohio. Short dismissed the Ohio School as "a Yankee, underbidding establishment" that produced doctors "upon as cheap terms as they do hats or shoes." Dr. Short and his colleagues did surmise though, that both medical schools could prosper because of the regional demand for medical education. 34 During his years in Lexington Professor Short taught at the medical school from November to March; the other months he devoted to the study of botany, an ancillary discipline of materia medica and medical botany. His personal library and herbarium attested to his scholarly interest in this academic field. Through Uncle William and his Philadelphia book dealer, Judah Dobson, Dr. Short subscribed to national and European journals and often purchased other scientific volumes. School was not in session during the spring, summer, and autumn seasons, when a botanist could study the stages of plant development. 
While in Lexington, as in Christian County, Charles traveled through Kentucky and neighboring states collecting, preserving, describing, and eventually exchanging specimens of western and especially Kentucky flora. 35

During the summertime, Dr. Short gardened, visited relatives and friends, read botanical and medical literature, and collected and preserved plants. On excursions around Lexington, his daughters often accompanied him and helped press, dry, and label plant specimens. They used a portable press of "two boards with leather straps and buckles." Years later, Dr. Short's eldest daughter Mary recalled these botanical trips: "Riding through the country in his carriage, with the doors tied open so that he could jump out at any moment when a new object attracted his attention, and with trunks, boxes, baskets, and curtains of the carriage rolled up full of plants, he seemed to be in a state of exquisite happiness." Other times, Short spent several days exploring a particular region. In June, 1832, for example, Dr. Short, his student Clarendon Peck, and Henry A. Griswold, a mathematics professor at Lexington's Eclectic Institute, spent four days searching for botanical specimens in central Kentucky and along the Kentucky River in Mercer County. The party investigated the area at Shaker ferry, opposite the Kentucky Cliffs or Palisades, which Charles regarded as one of the most beautiful sites and richest botanical resources in the Commonwealth. On these trips, Dr. Short gathered many specimens of each plant species to preserve in his herbarium or to send to. 
correspondents. 36

Dr. Short used the Transylvania Journal as an outlet to promote the study of botany and his scientific and medical interests in this area. In an essay on vegetable materia medica, he emphasized the importance of botany and its alliance to medicine and called attention to so-called "botanical physicians" or "steam doctors," who made medical potions by combining steam and vegetables. Professor short warned that these medicine men were neither physicians nor botanists, but disreputable quacks. In another article, he encouraged his fellow western physicians to cultivate home-grown plants with medicinal properties to obtain superior quality drugs. For example, he wrote detailed instructions on the planting, tending, and harvesting of Papaver Somnifer (white poppy), which produced the common drug, opium. Short considered gathering the crop easy enough for children to successfully perform. 37

During the summer of 1827 , Professor Short had taught a medical school class in botany and realized the need for a complete, systematic catalogue on local flora. He was familiar with similiar catalogues written by Jacob Bigelow, of Boston, William P.C. Barton, of Philadelphia, and William Darlington, of West Chester, Pennsylvania. While in Hopkinsville, Dr. Short had corresponded and exchanged specimens with Bigelow and Barton. In 1827 , at Daniel Drake's suggestion, Dr. Darlington had solicited plants from Dr. Short for the Chester County Cabinet of Natural Sciences. Darlington encouraged Dr. Short to 
publish a catalogue on western flora, which could be disseminated to eastern botanists. In a prospectus, short announced his plans to compile and publish in several numbers of the Transylvania Journal a descriptive catalogue of plants indigenous to the Lexington area. To aid his students, plants would be arranged by flowering seasons, rather than conventional classification methods. Each entry would include the plant's genus, an explanation of the derivation of the Latin or Greek name, a description of the genus, name of species and description, common names, and general observations. Although not a complete catalogue of flora of the Lexington neighborhood, the articles would serve as a reference work for his students in the medical school, as well as botanists in the West, and the nation. 38 Short was a descriptive botanist and a commentator on the development of North American botany and, in particular, his native west. In his article "Bibliographia Botana," (1835) Dr. Short reviewed recent publications of international and national acclaim on American botany and also devoted attention to the history of botany in North America. He examined select botanical catalogues, monographs, and manuals; recognized individual botanists for their scientific contributions in the form of publications, teaching, and plant exchanges; and acknowledged the establishment of community natural history or botanical organizations, which indicated a public interest in the sciences. Dr. Short listed himself among the noteworthy botanists and stated that in 1835, he had sent at least 
15,000 specimens of western plants to Europeans and Americans. 39

In this 1835 essay, Dr. Short also noted the controversy among American botanists about the use of the natural system of plant classification perfected by Antoine-Laurent de Jussieu and Augustin-Pyramus De Candolle and the older artificial method devised by the Swedish botanist Linneaus in the eighteenth century. By the $1830 \mathrm{~s}$, most European and many American botanists had come to endorse the natural method, which emphasized the study of the entire plant and specifically its form and structure. Other botanists in the United States, however, still preferred the Linnaean or artificial method, whereby plants were classified according to their sexual characteristics, such as the number of styles and stamens. Those who favored the natural method complained that the Linnaean system was too rigid and subject to arbitrary taxonomic decisions, whereas advocates of the artifical system, such as $\mathrm{Dr}$. Short, considered the older method easier to learn, especially for the amateur. While these latter botanists continued to promote the general knowledge of botany as an area of natural history, their colleagues argued that taxonomy had evolved into a scientific discipline dependent upon trained botanists. Short expressed his concern that the methods and principles of the natural system were incomplete and inappropriate for universal application, but he voiced his future support of the classification system if it proved acceptable to the general good of science. 40 
As early as 1833, Dr. Short planned to publish a book on the flora of Kentucky. Typically, Uncle William bestowed unsolicited advice about the subject. He did not deny the scholarly merits of the proposed work, Uncle William warned, however, that the limited number of national and European readers could not support such a volume. In 1835, Charles claimed that he could finance the book, but due to incomplete research, predicted it was years from publication. Dr. Short possibly feared that his book would be considered the definitive: work on Kentucky botany and might receive unjust academic criticism. 41

Unfortunately, Short's proposed Flora was never published. Nevertheless, he wrote a catalogue on Kentucky botany which appeared in five journal articles dating from 1833 to 1840. Short, Henry A. Griswold, and Robert Peter, collaborated on the first issue of the catalogue. In 1833 Peter was on the faculty of Transylvania's Morrison College. Later, he attended and was graduated from the university's Medical Department, and in 1838 he was elected to that department's chair of chemistry and pharmacy. Peter and Short wrote the next two installments of the Kentucky catalogue, while the latter compiled the remaining supplements. Short's colleagues welcomed his catalogue of Kentucky flora. Constantine S. Rafinesque, the former Transylvania professor, snobbishly asked if short would "ever publish any thing on the Flora of Kent'y besides a mere Catalogue." In 1835, Dr. Short sent Rafinesque a parcel of plants and asked the former Transylvania professor 
to return the favor with specimens of plants he had discovered in Kentucky. When Rafinesque forwarded familiar Kentucky plants, Short assumed that Rafinesque had falsified information about non-existent plants. Outraged, Short called Rafinesque "a Madman" and suggested that American botanists collect money to pay the former Kentucky resident an annuity for life in exchange for his silence on botanical discoveries $: 42$

Rafinesque also criticized Dr. Short's plant preservation methods, specifically noting that he pressed the plant "too much, so as to obliterate the angles \& grooves of [the] stems." Other botanists, however, praised Short for his beautifully prepared specimens, which were always a source of compliments to him. Later, Short altered his method of pressing and drying plants to accommodate Rafinesque's observations. In his "Instructions for the Gathering and Preservation of Plants," (1833), Short wrote a letter to an unknown botanist and described the fundamental procedures of plant collection, drying, and arrangement for a herbarium. He hoped the article would result in the employment of better preservation methods among botanists and thus upgrade the quality of specimens offered for exchange. Today, the essay serves as an interesting and informative guide to early nineteenth-century field botany. 43

Dr. Short's writing and plant exchanges brought him recognition as an authority on western botany. Many sought his correspondence and plant specimens for their study. At 
that time, botanists concerned themselves with identifying plants and studying their geographic distribution. Short, like other botanists, sought dried plants from American and European colleagues in his attempt to collect eventually a complete set of known North American plants, as well as European specimens. In 1831, at least two distinguished scientists wrote him for assistance. Thomas Say, the entomologist and conchologist, and his wife, Lucy, who were living in New Harmony, Indiana, supplied Dr. Short with plants and seeds of the Wabash River Valley. Mrs. Say also asked short to identify some plants in her herbarium. More significant, however, was John Torrey's request to Dr. Short that year. Professor of chemistry at the New York College of Physicians and Surgeons, Torrey was also a botanist and expert on American flora.

Dr. Torrey won scientific recognition for his Flora of the Northern and Middle Sections of the United States (1824), in which he described known American plants. He asked Dr. Short to be his botanical contact in the West and to supply him with flora in exchange for flora of the eastern United States and foreign plant specimens. 44 In 1832 William Darlington suggested that Dr. Short establish correspondence and botanical exchanges with William Jackson Hooker, Regius Professor of Botany at the University of Glasgow, author and editor of Curtis's Botanical Magazine, and recognized internationally for his research and publications. Darlington wrote to Hooker about his friend in the American West. Shortly thereafter, Hooker 
addressed Professor Short and offererd to exchange plants with him. To Charles, this was probably the highest professional honor he had received. "It is strange that an unknown, backwoodsman of Kentucky should feel flattered by the correspondence of such a man," he remarked to Uncle William. Charles reported that he had replied in a "plain, democratic and uncourtly" manner to Hooker's invitation and instructed Uncle William to ask Judah Dobson to forward his European packages to Kentucky. 45

By November, 1832, Dr. Short had prepared for Hooker a box of dried plants and seeds from the Lexington area. After examining the gift, Professor Hooker expressed his approbation of Short's skillfully prepared specimens. Hooker shared some of the Western American plants with Francis Boott, an American physician and botanist who lived in London, where he served as secretary to the Linnaean Society. Upon admiring and studying Short's "beautiful plants," he asked the donor to become his correspondent and named one of the plants, an aster (Aster Shortii) for him. During the next decade, Dr. Short periodically shipped parcels of plants to the distinguished British botanist Hooker. In 1834, for example, short constructed a box from "wild cherry," which was commonly used for frontier furniture, for the inclusion of some 850 specimens of Kentucky flora for Professor Hooker. To secure the dried plants, Dr. Short packed them with chips of different types of wood peculiar to the Commonwealth. 46 Dr. Short wrote a comprehensive article on western 
botany at the suggestion of his British correspondent Hooker. First published in the Transylvania Journal and reprinted by Hooker in that Journal of Botany, this piece communicated Short's observations on botany in the American West to his European and eastern American colleagues. Noting the specialization, progress, and public recognition of the natural sciences and, in particular, botany, Dr. Short recounted the work and contributions of both government and privately-supported western expeditions, botanists, their herbaria, and publications. He recognized the past work of other Kentucky residents, such as Daniel Drake, C.S. Rafinesque, and Henry McMurtrie, a physician and author of Sketches of Louisville and Its Environs (1819). He also provided a directory of living western botanists. Finally, he discussed his work on the botany of the Barrens in western Kentucky, exploration of the environs of Lexington, and the Kentucky and Ohio River regions. Short referred the reader to his essays on Kentucky botany in the Transylvania Journal and noted that he had distributed at least 25,000 plants to European and American botanists. From his explorations and collections, Dr. Short still planned to publish a Elora of Kentucky. 47 While Charles wrote about the progress of botany in the American West, he also kept Uncle William apprised of his personal life and community events. In 1833, for example, Charles reported the perils of the Asiatic cholera scourge in Kentucky. By May of that year the epidemic had hit the Ohio River town of Maysville, Kentucky, and by the 
next month, had spread to Lexington. An inland town situated at a higher elevation than the river valley communities, Lexington had been considered one of the healtheist cities in the city in the Commonwealth. Although Asiatic cholera was contagious and transmitted by contaminated water, most Kentucky physicians speculated that the disease resulted from the poisonous gases emitted from rotten vegetable matter. By mid-June, Dr. Short reported that the disease had claimed the lives of at least 350 Lexingtonians, "from among the most respectable, sober, and useful citizens," and he "had not heard of the death of one solitary drunkard!" The epidemic took more lives before it subsided in July, 1833.48

Charles understandably reserved news about the increase of his family for his brother rather than Uncle William, who preached a doctrine of thrift and moderation. From 1828 to 1836, Mary had four children: Sarah Elizabeth (1828), Lucy Ridgely (1831), Armistead Churchill (1833), and Abby Catherine (1836). Upon announcing the birth of his daughter Sarah, who was called Sally, Charles lamented to his brother that he wished they were all boys. He undoubtedly rejoiced in the birth of Armistead Churchill, his second surviving son. On the day after Christmas, 1836, the child, who his father described as "a fine little boy" died after a long illness. 49

Charles frequently informed Uncle william about the management of Transylvania University and the affairs of the Medical Department. He reported one controversy, in 
particular, which became a turning point for the Lexington medical school and its faculty. Early in 1826, Benjamin Winslow Dudley, professor of anatomy and surgery, suggested privately to his colleagues that the Medical Department move to Louisville. Several factors, including a lack of human cadavers, but more significantly, Lexington's economic decline, influenced the faculty's interest in relocation. According to Short, the faculty unanimously endorsed Dudley's proposal and sought the state legislature's approval. Although some medical students publicly advocated the move, many Lexington residents, as well as the school's board of trustees, opposed the resolution. Louisvile and Lexington newspapers carried letters from opponents and proponents of the issue, and editorials about the school's relocation heightened public interest. 50

At this point, Dr. Short noted that two professors, both extensive property owners in Fayette County, were now silent on the subject. Most likely he referred to Drs. Richardson and Dudley, who soon thereafter openly opposed the move, although the latter had been the original perpetrator. As the interested parties awaited legislative action, Dudley probably suspected that the resolution faced defeat; therefore, in January, 1837, he called upon the Transylvania trustees to investigate the matter. The board members agreed to conduct the inquiry but scheduled it for the end of the school session. 51

Meanwhile, Louisville civic leaders had promoted the transfer of the Transylvania Medical Department to; their 
city. They also sought a separate state charter for the establishment of a medical school in Louisville, in case the Transylvania relocation measure failed. Charles speculated that if a competitive medical school opened in Louisville, real estate values and the Lexington economy could experience a further decline; hence, Dudley and Richardson's retraction. On the other hand, according to Short's Louisville friend and former Lexington resident, Henry $A$. Griswold, Louisville property owners supported their city's move to open a medical school, which could boost the general prosperity of the Falls City. 52

Before the legislature adjourned in the spring of 1837, the resolution for relocation was defeated and a separate charter for a medical school in Louisville was not approved. On March 6, 1837, Councilman James A. Guthrie, a lawyer and advocate of municipally-supported educational institutions, offered a resolution to the Louisville city Council which called for the city to set aside land and money for the establishment of a medical school under an 1833 charter, which had authorized the founding of the Louisville Medical Institute. 53

On March 10, 1837, Lunsford Pitts Yandell wrote to his colleague Short about these developments. Louisville representatives had approached several Transylvania professors about positions in the Louisville school. Yandell urged Short to put aside his "habitual caution" and accept a position in Louisville. He also reminded Dr. Short of their conviction that Lexington was no longer the more 
suitable site for a medical school. Evidently, Yandell had already decided to move to Louisville. Later that year, Dr. Yandell wrote that by March both Professors Caldwell and Cooke had elected to leave Lexington for Louisville. 54

Faced with these prospects, the Transylvania trustees, at Dudley's prodding, identified Caldwell and Yandell as the instigators and held hearings about their involvement. in the removal scheme. When $\mathrm{Dr}$. Caldwell failed to honor the trustees' summons, they dismissed him and then dissolved the medical facult.y. Professors Caldwell, Cooke, and Yandell accepted positions in the reorganized Louisville Medical Institute and their former colleagues, Drs. Dudley, Richardson, and Short, were reinstated at Transylvania. 55

The officers of the Louisville Medical Institute offered Dr. Short the position in materia medica and medical botany. His former colleagues urged him to accept the chair. Charles considered the appointment and sought Uncle William's advice. Although he admitted that his distance prohibited a thorough understanding of the matter, Uncle William, nevertheless, encouraged Charles to move to Louisville, a populous city with a favorable geographical location and a demonstrated commitment to a municipal medical school. 56

Finally, Dr. Short accepted a reappointment to Transylvania. He based his decision on several factors: the 1833 Louisville Medical Institute charter made no specific provisions for granting degrees; the procurement of a new charter for a Louisville school had failed and was now 
a remote possibility; the financial panic of 1837 could affect the city's support of the new school; and he would probably suffer a personal financial loss if he moved to Louisville. To Uncle William, moreover, Charles confessed his dislike for the three departed professors: Dr. Caldwell was "arrogant and overbearing," Dr. Cooke spent too much time on theological matters, and Dr. Yandell was "beyond all question one of the most imprudent men" he had known. Above all, Dr. Short acknowledged that positions at Louisville as well as Cincinnati would remain options for him. Dr. Caldwell accused short of timidity for refusing the Louisville offer; Short, however, thought he had taken the wiser course. 57

When the Transylvania Medical Department began its winter session in 1837 , four new faculty members joined Short, Richardson, and Dudley. In a move that undermined their rival Cincinnati school, the Transylvania trustees appointed professors from the Medical College of Ohio to the three vacant chairs: theory and practice, Dr. John Eberle; chemistry and pharmacy, Dr. Thomas D. Mitchell; and institutes of medicine and medical jurisprudence, Dr. James C. Cross. The board also hired Dr. James M. Bush, an 1833 graduate of the Transylvania Medical Department and protégé of Professor Dudley, to the newly-created position of adjunct professor of anatomy and surgery. Professor Cross served as dean of the faculty, a position Dr. Short had resigned effective with the faculty reorganization. Upon his retirement as dean, Short's colleagues had presented him 
with a copy of William Hooker's Flora Boraeli-Americana in recognition of his service to the faculty, students, and school. 58

With one eye on Louisville, Charles continued to study his professional and personal situation and opportunities. In December, he reported to Uncle William that Transylvania's enrollment had not suffered as a result of the rival school in Louisville; the Lexington school, however, faced stringent financial conditions and had solicited money from private, donors. According to Dr. Short, Benjamin Dudley contributed to the cause as remorseful atonement for his part in the faculty reorganization. During the winter, Professor Eberle, former editor of The American Medical Recorder and author of Treatise on the Materia Medica and Therapeutics (1823) and Notes of Lectures on Theory and Practice on Medicine (1834), became ill and died before the end of the school session. His loss meant added class preparations for Professors Short and Mitchell. With the resignation of Thomas $W$. Coit before the 1837 session, the university again operated without a president. Mindful of these unsettled conditions, Dr. L.P. Yandell, on behalf of the Louisville Medical Institute, again tried to persuade Dr. Short to join him in Louisville. Dr. Short agreed to make a decision at the end of the school term. 59

Dr. Short had remained loyal to the Transylvania medical faculty, but he realized that Louisville had overtaken Lexington in urban prosperity. Lexington medical 
professors could no longer exist on matriculation fees, a factor that would affect the school's recruitment of reputable faculty members. Lexington and Transylvania showed signs of a declining economy, whereas Louisville now supported a promising medical school. After the school session ended, Charles went to Louisville. On April 7 , 1838, he met with members of the Louisville faculty and agreed to apcept a position there. That evening at the school's board of managers meeting, Charles Wilkins Short was unanimously elected to the chair of materia medica. 60 On April 9, 1838, Dr. Short resigned his professorship in the Transylvania Medical Department. The next day he informed his brother-in-law and colleague, Benjamin Dudley, of the decision and asked for his continued friendship. Dudley, who had a reputation for being easily angered, returned the letter unopened. Troubled by Dudley's reaction, Charles wrote to Uncle William, "I have managed to get through life so far, with so little quarrelling; and have been so fortunate as to keep on good terms with nearly all those whom I have had intercourse with; and all things have so utterly abhorred everything like family feuds, that I confess this procedure of the Doctor has surprized and pained me." Apparently, the unopened letter was Dudley's last personal contact with Charles. 61

Dr. Short's departure from Lexington signaled the end of his most active professional years. He had served as dean of the medical faculty and to his favor had remained on good terms with all parties during the medical department 
crisis in 1837. He had co-founded and co-edited the school's first medical journal, The Transylvania Journal of Medicine and the Associate Sciences. In Lexington, he had written all but three of his major publications. From 1833 to 1838 , Dr. Short had distributed approximately 28,800 specimens of primarily Kentucky flora to at least thirty-seven naturalists. These correspondents relied on his expertise on Kentucky and its regional botany and complimented his skillfully prepared dried plants. Dr. Short's election in 1835 to the American Philosophical Society in Philadelphia brought him personal honor as well as formal recognition for his scientific contributions. In 1825, Charles had looked forward to returning to the Bluegrass, the land of his nativity and childhood. During his thirteen years on the Transylvania medical faculty, Professor Short increasingly came to think of his teaching as a task, but his botanical work provided a source of satisfaction. Country life still appealed to him. He dreamed of owning a small estate sustained by a dependable income. Unknown to him, this wish would come true, but not in the Bluegrass. 62 
${ }^{1}$ Charles Wilkins Short to William Short, August 24, 1825, December 30, 1825, Charles Wilkins Short Papers, File 2, Filson Club, Louisville, Kentucky (hereinafter SPFC); C. W. Short to John Cleves Short, September 12, 1849, Symmes, Harrison and Short Family Papers, Library of Congress, Washington, D.C., microfilm in the Filson Club (hereinafter SHSLC); C.W. Short to W. Short, September 7, 1825, File 14, SPEC.

${ }^{2}$ C. $\dot{W}$. Short to Samuel Younglove, April 29, 1840 , File 93, SPFC; C.W. Short to W. Short, September 7, 1825 , October 25, 1825, File 14, SPFC; W. Short to C.W. Short, November 12, 1825, File 3, SPFC; DAB, 17: 128-129; Short v. Short, U.S. Seventh Circuit Court Records, 1826-1827, pp. 124-125, United States District Court, Lexington, Kentucky.

3 Will of Peyton Short, Christian County will Book, Volume D, pp. 318-319, Kentucky State Archives, Frankfort, Kentucky; C.W. Short to W. Short, October 25, 1825, December 20, 1825, File 14, SPFC; W. Short to C.W. Short, November 12, 1825, File 3, SPFC; C.W. Short to W. Short, April 15, 1826, File 15, SPFC; George Green Shackelford, "William Short, Jefferson's Adopted Son, 1758-1849" (Ph.D. dissertation, University of Virginia, 1955), pp. i-x; Wilkins to W. Short, August 24, 1826, File 55, SPFC; C.W. Short to J.C. Short, November 2, 1826, November 27, 1826 , December 24, 1826, SHSLC; C.W. Short to Younglove, April 29, 1840, File 93, SPFC.

${ }^{4}$ C.W. Short to W. Short, october 25, 1825, File 14, SPFC; C.W. Short to J.C. Short, october 30, 1825, Charles Wilkins Short Papers, American Philosophical Society Library, Philadelphia, Pennsylvania (hereinafter SPAPS); C.W. Short and Mary Churchill Richardson, "A Chronological Record of the Families of Charles Wilkins Short and Mary Henry Churchill," 1843, 1879, p. 155, SPFC.

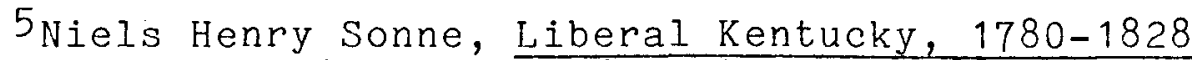
(Lexington: University Press of Kentucky, 1966; originally published 1939), pp. 242-261; DAB, 5: 254-255;9: 149-150.

6 Sonne, Liberal Kentucky, pp. 242-261; C.W. Short to W. Short, November 30, 1828; DAB , 9: 149-150.

7 DAB , 3: 406; 5: 478-479; Kentucky Reporter, August 1,1825, p. 3 , August 29,1825, p. 3 .

${ }^{8} \mathrm{C} . \mathrm{W}$. Short to W. Short, October 25,1825 , November 18,1825 , November 26, 27, 1825, December 30, 1825, File 14, 
SPFC.

${ }^{9}$ C.W. Short to J.C. Short, December 1, 1825, SPAPS; C.W. Short and Richardson, "A Chronological Record of the Families of C.W. Short and Mary Henry Churchill," pp. 11 , 27, 155, SPFC; C.W. Short to Mary Churchill Short, January 12, 1826, Charles Wilkins Short Papers, Southern Historical Collection, University of North Carolina, Chapel Hill, North Carolina (hereinafter SPSHC).

10 W. Short to C.W. Short, January 14,1826 , File 4 , SPFC; C.W. Short to W. Short, January 24, 27, 1826, File 15, SPFC; Wilkins to W. Short, April 8, 1826, File 55, SPFC; W. Macbean to C.W. Short, April (n.d.), 1826, Charles Wilkins Short Papers, Special Collections and Archives, Margaret I. King Library, University of Kentucky, Lexington, Kentucky (hereinafter SPUK); C.W. Short to J.C. Short, April 6, 1826, SHSLC.

${ }^{11} \mathrm{C} . \mathrm{W}$. Short to W. Short, April 15, 1826, May 10 , 1826, File 15, SPFC; C.W. Short to J.C. Short, May 3, 1826, June 26, 1826, August 4, 1826, SHSLC; C.W. Short to W. Short, May 15, 1826, SPSHC; C.W. Short and Richardson, "A Chronological Record of the Families of C.W. Short and Mary Henry Churchill," pp. 155-156, SPFC.

12 Richard Wade, The Urban Frontier, The Rise of Western Cities, 1790-1830 (Cambridge: Harvard University Press, 1959), pp.177-189, 210-211, 232-233; George Washington Ranck, History of Lexington, Kentucky

(Cincinnati: Robert Clarke, 1872), p. 303 .

$13 \mathrm{C}$. W. Short and Richardson, "A Chronological Record of the Families of C.W. Short and Mary Henry Churchill, "pp. 155-156, SPFC; W. Short to C.W. Short, September 14, 1826, File 4, SPFC; C.W. Short to W. Short, December 4, 1826, File 15, SPFC; C.W. Short to W. Short, November 30, 1828, File 17, SPFC; The Lexington Intelligencer, August 31, 1838 , p. 3; C.W. Short to J.C. Short, August 21, 1826 , October 8, 1826, SHSLC; Kentucky Reporter, February 3, 1827, p. 4; Kentucky Gazette, February 23, 1827 , p. 4 .

${ }^{14} \mathrm{C}$. W. Short to J.C. Short, December 24,1826 , SHSLC; C.W. Short to W. Short, April 16, 1827, File 16, SPFC.

$15 \mathrm{C}$. W. Short to J.C. Short, September 12,1826 , October 8, 1826 , SHSLC; Irving Frederick Ahlquist, "Ohio Valley Culture as Reflected in the Short Family, 1790-1860" (Ph.D. dissertation, University of Illinois, 1947), pp. $37-47$.

16 Thomas Matthews to C.W. Short, July 7,1826 , File 66, SPFC; C.W. Short to J.C. Short, October 2, i826, SHSLC; Cincinnati Literary Gazette, March 13, 1824, pp. 86-87. 
17 C.W. Short to W. Short, December 4, 1826, File 15, SPFC; Kentucky Gazette, January 13, 1826, p. 4; Lewis Cecil Gray, History of Agriculture in the Southern United States to 1860,2 vols. (New York: Peter Smith, 1941), 2 : 696-700. Following the Panic of 1819, short-staple cotton prices fell to an annual price of $11.5 \notin$ per pound in 1822, but showed an upward gain to $17.9 \notin$ by 1824 . The price peaked in June, 1825, and beginning that fall and throughout the next two years prices declined to a low of $8.8 \%$ per pound.

SPFC.

${ }^{18}$ C.W. Short to W. Short, December 4, 1826, File 15,

$19 \mathrm{~T}$ [heodore] $\mathrm{S}$ [tout] Bell, Lecture Notes, 1830-1831, Kentucky Division, Louisville Free Public Library, Louisville, Kentucky; C.W. Short to J.C. Short, November 24 , 1858, SHSLC; DAB, 10: 222-223.

20 Transylvania University, Medical Department Minutes, March 12, 1827, March 7, 1829, Special Collections, Frances Carrick Thomas Library, Transylvania University, Lexington, Kentucky (hereinafter SCTU).

${ }^{21}$ Catalogue of the officers of the Medical Department of Transylvania University and the Graduates of 1828, pp. 7-8, SCTU; Wright, Transylvania, pp. 119-120.

${ }^{22}$ C.W. Short to John Bradford, January 1, 1829, SCTU; Wright, Transylvania, pp. 119-120.

23 C.W. Short to W. Short, February 17, 1828, File 17, SPFC; Kentucky Reporter, March 26, 1828, p. 1; Emmet Field Horine, Daniel Drake $(1785-1852)$ : Pioneer Physician of the Midwest (Philadelphia: University of Pennsylvania Press, 1961), p. 167, DAB, 4: 384-385.

24 "Prospectus," Transylvania Journal of Medicine and the Associated Sciences 1 (February 1828): 5-6; Thomas Cary Johnson, Jr., Scientific Interests in the old South (New York: D. Appleton-Century Company, 1936), p.80. C.W. Short to W. Short, December 4, 1827, File 16, SPFC.

25 The American Medical Recorder 14 (July 1828): 163-164; Henry Burnell Shafer, The American Medical Profession, 1783 to 1850 (New York: Arno Press, 1968; originally published 1936), pp. 11-12; Richard Shryock, Medicine and Society in America; $1660-1860$ (Ithaca, New York: Cornell University Press, 1960), pp. 117-174.

1828): $1-8$.

26 "Suum Cuique," Transylvania Journal, 1 (August

27 C.W. Short, "Biographical Notice of Frederick Ridgely," Transylvania Journal 1 (August 1828): 442-448; 
Short, "Obituary Notes, David Meade," Transylvania Journal 2 (May 1829): 298; Charles Kerr, ed., History of Kentucky, 5 vols. (Chicago and New York: The American Historical Society, 1922), 1: 524-525.

${ }^{28} \mathrm{C}$. W. Short, "Case of Spontaneous Combustion of the Human Body," Transylvania Journal 3 (February 1830): $143-145$.

${ }^{29}$ C.W. Short, "Valedictory Address," Transylvania Journal 1 (August 1828): 39, 304-309; C.W. Short and H. Hulbert Eaton, "Notices of Western Botany and Conchology," Transylvania Journal 4 (February 1831): 69-82; C.W. Short to W. Short, Janaury 31, 1834, File 19, SPFC; C.W. Short, "A Biographical Memoir of H. Hulbert Eaton, A.M.,"

Transylvania Journal 5 (October-December 1832): 59, 470-481. Based on catalog listings of professors, preceptors, and students, Dr. Short accepted only four pupils for private studies while he was on the Transylvania faculty.

30 Wright, Transylvania, pp. 124-125; Charles Caldwell to C.W. Short, May 24, 1829, File 66, SPFC; C.W. Short to W. Short, June 29, 1829, File 17, SPFC; C.W. Short, Extra, July 18, 1829, SCTU.

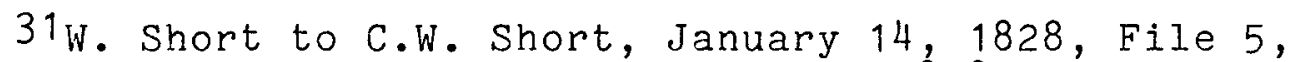
SPFC; C.W. Short to W. Short, February 17, 1828, File 17, SPFC; Wright, Transylvania, pp. 99-107, 118-119, 127-132; DAB, 20: $500-\overline{501 .}$

${ }^{32} \mathrm{C} . \mathrm{W}$. Short to W. Short, November 8, 1829 , December 13, 1830, File 17, SPFC; Wright, Transylvania, pp. 118-119, $127-132$.

33 Robert Peter, The History of the Medical Department of Transylvania University (Louisville: John P. Morton \& Company, 1905), pp. 82-83 fn, 153, 160; M.C. Johnson to C.W. Short, n.d., SPUK; Wright, Transylvania, pp. $118-119,127,132-139,145-146 ;$ DAB , 4: 278-279; 14: 389; C.W. Short to W. Short, June 8, 1834 , File 19, SPFC.

34 Transylvania University, Medical Department Announcement, August 8, 1831, File 18, SPFC; DAB, 20: 596-597; C.W. Short to W. Short, August 14, 1831, December 20, 1831, File 18, SPFC; C.W. Short to W. Short, February 17,1828, File 17, SPFC.

35C.W. Short to W. Short, April 16, 1827, File 16, SPFC. Some seventy books from Short's coliection were donated in 1943 to the University of Louisville Rare Books Department. See The Cardinal, February 19, 1943, University of Louisville Archives, Louisville, Kentucky (hereinafter ULA). 
${ }^{36}$ C.W. Short to J.C. Short, June 30, 1832, SHSLC; C.W. Short and Richardson, "A Chronological History of the Families of C.W. Short and Mary Henry Churchill," p. 161, SPFC; C.W. Short to William Jackson Hooker, January 20, 1834, North American Letters, 1832-1834, vol. LXI, no. 186, Royal Botanical Gardens Library, Kew, Great

Britain (hereinafter RBG); C.W. Short, "A Sketch on the Progress of Botany in Western America," Transylvania Journal 9 (April-June 1836): 348 .

37C.W. Short, "An Introductory Address to a Course of Lectures on Materia Media," Transylvania Journal 6 (October-December) 1833: 58, 464-474; C.W. Short, "On the Cultivation of Certain Medicinal Plants," Transylvania Journal 2 (November 1829): 512-523; William G. Rothstein, American Physicians in the Nineteenth Century: From Sects to Science (Baltimore: Johns Hopkins University Press, 1972), pp. 128-151; Shafer, The American Medical Profession, pp. 200-203. Short may have: been referring to followers of Samuel Thomson (1769-1843), a farmer and founder of an unorthodox medical sect who combined steam and vegetables to produce medicinal remedies. In 1813 Thomson patented his system and in 1822 published a New Guide to Health and the Narrative which established his reputation and led to his participation in the patent medicine business.

\section{${ }^{38} \mathrm{DAB}, 2: 25-26,257-258 ; 5: 78-79$; Kentucky} Reporter, April 11, 1827, p. 3; William Darlington to C.W. Short, June 4, 1827, February 21, 1828, Botanical Correspondence, vol. 1, SPFC; C.W. Short, "Prodromus Florulae Lexingtoniensis, Secundum Florendi Aetatem Digestae (Proposal for a Descriptive Catalgoue of Phaenogamous Plants Indigenous to this Portion of Kentucky),"

Transylvania Journal 1 (February 1828): 92-99; C.W. Short, "Florula Lexingtoniensis, secundum Florendi Aetatem Digestae: or a Descriptive Catalogue of the Phaenogamous Plants Indigenous to this Portion of Kentucky," Transylvania Journal 1 (May 1828): 560-575, 1 (August 1828): 52, 408-422; 1 (November 1828): 560-575, 2 (August 1829): $438-453$.

${ }^{39} \mathrm{C}$. W. Short, "Bibliographica Botanica," Transylvania Journal 8 (October-December 1835): 553-574.

40 Ibid., Andrew Denny Rodgers, III, John Torrey: A Story of North American Botany (Princeton: Princeton University Press, 1942), pp. 78-81; A. Hunter Dupree, Asa Gray, 1810-1888 (New York: Atheneum, 1968; originally published 1959), pp. 27-29; C.W. Short to Asa Gray, June 23, 1836, Asa Gray Papers, Gray Herbarium Library, Harvard University, Cambridge, Massachusetts (hereinafter AGHU); DSB $, 3: 43-45 ; 7:$ 198-199.

${ }^{41}$ C.W. Short to W. Short, May 20, 1833, File 18, 
SPFC; W. Short to C.W. Short, October, 15, 1834, File 6, SPFC; C.W. Short to W. Short, January 31, 1835,' File 19, SPFC.

42 [Charles Wilkins Short, Robert Peter, and Henry A. Griswold], "A Catalogue of the Native Phaenogamous Plants and Ferns of Kentucky," Transylvania Journal 6

(July-September 1833): 490-501; [Charles Wilkins] Short and [Robert] Peter, "A Supplementary Catalogue of the Plants of Kentucky," Transylania Journal 7 (October-December 1834): 598-600; [Charles Wilkins Short and Robert Peter], "A Second Supplementary Catalogue of the Plants of Kentucky," Transylvania Journal 8 (October-December 1835): 575-582; C.W. Short, "A Third Supplementary Catalogue of the Plants of Kentucky," Transylvania Journal 10 (July-September 1837): 435 [sic]-340; C.W. Short, "A Fourth Supplementary Catalogue of the Plants of Kentucky," The Western Journal of Medicine and Surgery 2 (October 1840): 283-288; DAB; 14: 449-500; C[onstantine] S. Rafinesque to C.W. Short, November 15, 1834, File 134, SPFC; C. W. Short to John Torrey, December 17,1834 , August 11,1835 , John Torrey Papers, New York Botanical Garden Library, Bronx, New York (hereinafter NYBG).

43 Rafinesque to C.W. Short, August 5, 1834, File 134, SPFC; Hooker to C.W. Short, February 19, 1833, Botanical Correspondence, vol. 1, SPFC; C. W. Short to Torrey, October 4, 1834, Torrey Papers, NYBG; C.W. Short, "Instructions for the Gathering and Preservation of Plants for Herbaria; in a Letter to a Young Botanist," Transylvania Journal 6 (January-March 1833): 8 [sic], 61-74.

$$
{ }^{44} \mathrm{C} . \mathrm{W} \text {. Short to Hooker, December } 7,1835 \text {, North }
$$
American Letters, 1835-1838, vol. LXII, no. 139, RBG; Thomas Say to C.W. Short, March 1, 1831, Botanical Correspondence, vol. 1, SPFC; DAB, 16: 401-402; 18: 596-598; Torrey to C.W. Short, March 21, 1831, Botanical Correspondence vol. 1, SPFC.

${ }^{45}$ Darlington to C.W. Short, January 18, 1832, March 5, 1832, Botanical Correspondence, vol. 1, SPFC; Hooker to C.W. Short, March 25, 1832, Botanical Correspondence, vol. 1, SPFC; DSB, 6: 492-495; C.W. Short to Hooker, June 7 , 1832, North American Letters, 1832-1834, vol. LXI, no. 180, RBG; C.W. Short to W. Short, June 8, 1832, File 18, SPFC.

$46 \mathrm{C}$. W. Short to Hooker, November 18,1832 , January 20 , 1834, North American Letters, 1832-1834, vol. LXI, nos. 181, 186, RBG; Hooker to C.W. Short, February 19, 1833, Botanical Correspondence, vol. 1, SPFC; Francis Boott to $\mathrm{C}$. W. Short, March 28, 1833, Botanical Correspondence, vol. 1, SPFC.

$47 \mathrm{C} . \mathrm{W}$. Short, "A Sketch of the progress of Botany in Western America," Transylvania Journal 9 (April-June) 1836: 324-350, The Journal of Botany 3 (November 1840): 97-124. 
48 Nancy D. Baird, "Asiatic Cholera's First Visit to Kentucky: A Study in Panic and Fear," Filson Club History Quarterly 48 (July 1974): 228-231, 237; C.W. Short to W. Short, June 16, 1833, June 23, 1833, File 18, SPFC.

${ }^{49} \mathrm{C}$. W. Short and Richardson, "A Chronological Record of the Families of C.W. Short and Mary Henry Churchill, " p. 11, SPFC; C.W. Short to J.C. Short, March 20, 1828, SHSLC; C.W. Short to W. Short, December 30, 1836, File 20, SPFC.

${ }^{50}$ C.W. Short to W. Short, March 20, 1836, File 19, SPFC; C.W. Short to W. Short, December 30, 1836, File 20, SPFC; John H. Ellis, Medicine in Kentucky (Lexington: University Press of Kentucky, 1977), p. 13; Kentucky Writers' Project of the Works Projects Administration, A Centennial History of the University of Lousiville (Louisville, Ky.: University of Louisville, 1939), pp. 23-37 .

${ }^{51} \mathrm{C} . \mathrm{W}$. Short to W. Short, December 30,1836 , File 20, SPFC; Wright, Transylvania, pp. 147-151; Louisville Journal, January $20,1837, \mathrm{p} .2$.

52Centennial History, pp. 23-37; H[enry] A. Griswold to C.W. Short, January 6, 1837, File 84, SPFC; C.W. Short to W. Short, December 30, 1836, File 20, SPFC.

53 Centennial History, pp. 23-37; Anna Ruth Spiegel, "Public Career of James Guthrie, 1792-1869," (M.A. thesis, University of Louisville, 1940), pp. 81-86; DAB, 8: 60-62.

${ }^{54} \mathrm{~L}$ [unsford] $P$ [itts] Yandell to C.W. Short, March 10, 1837, File 91, SPFC; Lunsford Pitts Yandell, A Narrative of the Dissolution of the Medical Faculty of Transylvania University (Nashville: W. Hasell Hunt, 1837), p. 3 .

${ }^{55}$ C.W. Short to W. Short, March 24, 1837, March 29, 1837, File 20, SPFC; Wright, Transylvania, pp. 147-150.

56 Centennial History, p. 42; Yandell to C.W. Short, March 10, 1837, April 27, 1837, File 91, SPFC; C.W. Short to W. Short, December 30, 1836, File 20, SPFC; W. Short to C.W. Short, Janaury 9, 1837, February 15, 1837, March 15, 1837, File 7 , SPFC.

57 C.W. Short to w. Short, May 29, 1837, October 28 , 1837, File 20, SPFC.

58 Transylvania University Announcement, July 25, 1837, SPSHC; DAB, 5: 615-516, 13: 66; C.W. Short to W. Short, August 2, 1837, File 20, SPFC.

59 c.W. Short to W. Short, August 20, 1837, October 28,1837 , December 20, 1837, File 20, SPFC; Transylvania Medical Department Minutes, January 4, 1828, pp. 159-160, 
SCTU; Yandell to C.W. Short, February 1, 1838, File 91, SPFC; C.W. Short to W. Short, February 6, 1838, February 25, 1838 , File 21, SPFC

$60 \mathrm{C}$. W. Short to M.C. Short, April 7, 8, 1838, File 130, SPFC; W.S. Vernon to C.W. Short, April 7, 1838, SPUK; C.W. Short to W. Short, April 8, 1838, File 21, SPFC.

${ }^{61}$ C.W. Short to Thomas A. Marshall, April 9, 1838, Lunger Catalog Collection, SCTU; C.W. Short to Benjamin W. Dudley, April 10, 1838, File 68, SPFC; Horne, Daniel Drake, p. 327; C.W. Short to W. Short, May 3, 1838, File 21, SPFC.

62 Chart of C.W. Short's Botanical Correspondence and Specimens Distributed from a Catalogue of Plants Collected, Preserved, and Distributed, 1833-1838," Box 1, Folder 2, Percy Albert Davies Papers, ULA; Early Proceedings of the American Philosophical Society, 1744 to 1838 (Philadelphia: Mccalla \& Stavely, 1884), p.663; C.W. Short to J.C. Short, January 4, 1829, SHSLC. 


\section{A NEW HOME IN LOUISVILLE}

Several months before his forty-fourth birthday, Dr. Short prepared for another career transition. Although he had been cautious in his decision to leave Lexington, he realized that Louisville offered economic advantages that outweighed his attachment to the Bluegrass. Charles observed that in one year the city of Louisville had demonstrated greater support of its medical school than the state government and Lexington had previously provided for Transylvania. He now turned his attention to a new job at the Louisville Medical Institute, which would become one of the largest and most prosperous medical schools in the West during the first half of the nineteenth century. The professors would be recognized for academic and professional contributions, as well as lucrative positions. Dr. Short, however, would not escape the controversy surrounding the new medical school.1

After he accepted the Louisville offer, Short began making arrangements for the school session. Uncle William, who had encouraged Charles to give up the "sinking ship" in Lexington, gave his nephew $\$ 2000$ to help pay his moving expenses and suggested that Charles rent or buy a house in Louisville, rather than undertake costly construction of a new residence. Unsure of securing a dwelling in Louisville 
and selling his Lexington home, Charles thought about leaving his family in Lexington and living alone in Louisville during the upcoming school term. Short decided against this plan, however, because many of his Lexington friends had become "cool, distant, or positively abrasive."2

The Shorts decided that they would move in time for the opening of school. In late July, Dr. Short went to Louisville to find a house for the family. While in the city, he admired the medical school building then under construction and claimed that it was "equal to anything of the kind in the Union, and very far superior to any in the West." He visited other faculty members and reported that they were "able, and I trust more honorable than those I have left." He returned to Lexington with his mission unaccomplished. 3

Around the first of September, 1838, Charles again traveled to Louisville where he rented a house at Number 3 Bainbridges' Row on the north side of Jefferson Street between Seventh and Eighth streets. Satisfied with his good fortune, he reported that the dwelling was "one among the best houses in the place," and spacious enough to accommodate his slaves and large family, which included his daughters Mary (18), Jane (12), Sally (10), Lucy (7), and Abby Catherine (2), in addition to his son William (14) and nephew Peyton Breathitt (16) who had been living with the Short family for about one year. Peyton's mother, Elizabeth short Breathitt, "a sister of Dr. Short's, had died in 1827 leaving her husband James with two young sons, Peyton and John. 
James Breathitt later remarried but he died in August, 1837 . Peyton, the older brother went to live with Dr. Short's family and Dr. Short's brother Cleves invited the younger brother to live at Shorthill. 4

The Shorts made preparations for their move which was scheduled for the first week of October. On September 22, their Lexington property, which consisted of three lots and included a "large and commodious dwelling house, smoke house, woodhouse, large cistern, [and] never failing well," was sold at public auction. While attending to these activities, the family cared for two-year-old Abby Catherine, who had been ill since summertime. On October 11, Charles wrote to Uncle William that his baby daughter was near death and could not travel. Charles' son, William, and nephew, Peyton, took charge of moving the household furnishings to their new home, while the remainder of the family stayed with friends. On October 18, 1838, Catherine died of consumption. She was the fourth of their nine children to die. The Shorts surely grieved the death of each one. Extant Short family correspondence, however, reveals little of their reaction to these events. Perhaps Dr. Short was so greatly affected by the loss of a child that he could not bear to relate anything except the facts. Or he might have thought that his sorrows were so personal that his strict sense of propriety prevented him from sharing his emotional responses with his correspondents. The day after the funeral the bereaved family left the Bluegrass for the Falls City. 5 When the Shorts arrived in Louisville they discovered 
a city unlike Lexington. Where the Bluegrass town suffered the economic consequences of its landlocked location, Louisville benefitted from its position on the Ohio River and steamboat technology. Louisville's geographical location spurred its growth as a commercial and industrial center which supported an increasing immigrant labor supply. By the late $1830 \mathrm{~s}$, the river city had developed a tobacco market, iron-making. industries, and meat packing houses. In 1830 , Louisville and its adjacent towns of Shippingport and Portland reported a population of 11,341 whereas Lexington recorded 6,087 inhabitants. In 1840 , Louisville's population swelled to 21,210 compared to Lexington's $6,997.6$

Dr. Short's residence was within walking distance of the new medical school. Although the building was incomplete when the 1838-1839 session began, classes were held in the new school rather than the city workhouse, where courses had been taught the previous term. Located several blocks from the city's business district, the Louisville Medical Institute occupied part of the square block bounded by Eighth, Ninth, Chestnut, and Magazine streets. Resident Kentucky architect Gideon Shryock had designed the commodious three-story structure along classical revival lines. The building's floor plan included three lecture rooms, each seating four to five hundred persons, six dissecting rooms, a chemistry laboratory, and a janitor's room. Dr. Short taught classes in materia medica in the medical hall, located at the west end of the building. A Louisville Medical Institute catalogue, issued the first day of 1839 , reported that the 
professor of materia medica would complement his lectures with medicines, plant drawings and engravings, and "dried specimens from the most extensive collection in the Western States."7

On the first Monday in November, 1838, Dr. Short joined his colleagues for the opening of the second session of the Louisville Medical Institute. Besides Short, the faculty consisted of six other professors:- Jedediah Cobb, anatomy; Charles Caldwell, institutes of medicine, clinical practice, and medical jurisprudence; John Esten Cooke, theory and practice; Joshua Barker Flint, surgery; Henry Miller, obstetrics and the diseases of women and children; and Lunsford P. Yandell, Sr., chemistry and pharmacy. A student paid $\$ 110$ to attend lectures and to have library privileges. He also had to purchase a $\$ 10$ dissecting ticket and pay a $\$ 10$ graduation fee, if applicable. In 1839, the institute's graduation requirements resembled those in other American medical schools: the student had to be at least twenty-one years old, possess good moral character, and attend two courses of lectures, of which the second was to be at the Louisville Medical Institute. A student could substitute four years of medical practice for the one course of lectures. Students were also expected to write a thesis in English, Latin, or French, and pass oral examinations. 8 Dr. Short served as dean of the medical faculty for the first three sessions of his tenure at the Louisville school. Uncle William remembered his nephew's complaints about the impositions and duties associated with the same 
office at Transylvania and expected him to decline the offer. Charles explained that the Louisville faculty had elected him to the position because of his experience, business abilities, and "consiliatory disposition." At first Short protested the faculty's request, but agreed to serve until the school's financial foundations were well-established. Although the position required more work and assured additional frustrations, Dr. Short recognized the faculty's calling as a compliment and he had confidence in his own abilities to execute the duties of the deanship effectively.9 The attraction of medical students to the new school was a major concern to the dean and his medical faculty. The school's enrollment increased from 80 students the first session to 120 the next session, which indicated the institution's rising reputation and prosperity. By 1840 at least thirty medical schools in the United States offered degree-granting programs and sixteen of those were located in New England, New York, and Philadelphia. Schools in the southern and western states met the needs of students who could not travel to the northeast for formal medical instruction. While Dr. Short taught in Louisville, major medical schools located in the ohio Valley and the old Southwest operated in Lexington, Cincinnati, St. Louis, New Orleans, and Memphis. Dean Short and his colleagues, nevertheless, were aware of competition from regional medical schools. In 1837 and 1838, for example, Transylvania University Medical Department had lost the majority of its faculty, so Transylvania's efforts to revitalize its medical 
program centered on the construction of a new building. When Dr. Short heard about the Transylvania plan, he questioned Lexington's ability to fund the proposed project and wrote Uncle William about Dr. Benjamin W. Dudley's support of the scheme. Charles derided his brother-in-law Dudley by suggesting that the Transylvania professor would "beggar his children" to assure the failure of the Louisville Medical Institute. 10

To Uncle William, Charles expressed optimism about the Louisville school and his association with it, but he revealed conflicting sentiments to his brother, cleves. In a confidential letter written only nine months after his move to Louisville, Charles told his brother that he contemplated leaving Louisville and possibly settling on a farm close to him near North Bend, Ohio. Charles disliked teaching and he wanted to live in the country rather than an industrial town. In response, Cleves urged his brother to reconsider his idea, because he thought Uncle William would be displeased with Charles for abandoning his chosen profession. He also warned Charles that if he left Louisville so soon after his arrival he risked dishonor; there were physicians and other persons who would accuse him of being incapable of enduring the crisis at Transylvania and his present duties at the Medical Institute. Perhaps Cleves was aware of his brother's occasional thoughts of resignation and escape to the life of a country gentleman. 11

During Dr. Short's last two years as dean, the Louisville Medical Institute continued to flourish. Early in 
September, 1839, Short went to Cincinnati, where he met with Dr. Daniel Drake, who had resigned his position in the Cincinnati College Medical Department, which subsequently closed. The Louisville faculty feared that if Drake returned to Transylvania, prospective Ohio medical students would follow the popular teacher. On behalf of the faculty, Short offered Drake a new professorship tailored to his interests, the chair of clinical medicine and pathological anatomy, which Drake accepted. The Louisville school, now the largest medical faculty in the West,: had eight full-time professors. 12

The addition of another faculty member could have been a financial risk for the young school, but the year Drake joined the institute its enrollment climbed from 120 to 204 students. Dean Short reported that Professor Drake's hospital instruction had been well received and noted that Transylvania could not boast of a comparable facility. The professors used the city-owned and -operated Louisville Marine Hospital for clinical lectures and training. Several Louisville professors, especially Drake and Caldwell, were interested in the study of clinical pathology as developed by contemporary French physicians. Through clinical observation, doctors studied and recorded information about patients' symptoms, compared and analyzed data, and further researched their findings by conducting autopsies. Clinical methods were best employed in hospitals where physicians had ample subjects for observation, examination, and study. To support their work and enhance medical instruction, the 
Louisville faculty jointly-financed the construction of a Clinical and Surgical Hall, a building connected to the Louisville Marine Hospital. Dr. Drake delivered the dedicatory address when the building opened on November 5 , 1840.13

Daniel Drake's contributions to the Louisville Medical Institute also included the revival of the school's medical journal. In 1838, Professors Lunsford P. Yandell, Henry Miller, and local physician Theodore S. Bell had edited a school-sponsored journal, the Louisville Journal of Medicine and Surgery, of which only two issues were published. Two years later Drake and Yandell edited the institute's second house publication, The Western Journal of Medicine and Surgery, which appeared monthly and was a merger of Drake's now defunct Cincinnati-based Western Journal of Medicine and the Physicial Sciences and the 1838 Louisville journal. Dr. Drake served as editor of The Western Journal of Medicine and Surgery from 1840 until 1849, a significant period in the history of the Louisville Medical Institute. Today the periodical is a source that reflects the political, social, intellectual climate of the school, especially through the writings of its professors, including Dr. Short. 14

At the end of the school's third session, the Medical Institute's board of managers called for the resignation of Joshua Barker Flint, the professor of surgery, who reluctantly complied with the request. Supposedly Professors Yandell, Caldwell, and Drake had accused Dr. Flint of being 
an ineffective lecturer and unpopular with the students. Immediately Flint drew support from a group of local physicians who advocated the operation of a city medical school the prosperity of which they could share. On May 22 , 1840, twenty-one resident physicians organized a meeting at the Louisville Hotel where they voiced their support of the school but called for the dismissal of the institute's board of managers, and professors. By this time, the issue had received wide publicity from local newspapers. Dean Short believed that if Flint could; be replaced with a competent and reputable professor, the local furor would not be as convincing. 15

Soon after the Louisville Hotel meeting, Dean Short went to Cincinnati on a faculty recruitment assignment. On behalf of the faculty and managers, he offered the vacant chair of surgery to Samuel David Gross, a professor of pathological anatomy at the Cincinnati Medical College. Dr. Gross, who had a favorable reputation as a teacher, surgeon, and medical writer, met Dr. Short's qualifications for the position. Two of the surgeon's books, Treatise on the Anatomy, Physiology, and Diseases and Injuries of the Bones and Joints (1830) and Elements of Pathological Anatomy (1839) had been recognized as important American contributions to medical theory and literature. After a visit to Louisville, Gross accepted the position. 15

Some local practioners thought that the institute's managers and professors should consider them for faculty appointments to the medical school. The administration and 
organization of the medical institute soon became an issue of local debate among various interest groups, including some resident doctors. At the time of the opening of the medical school in 1837 , the city council had stipulated that if Louisville were to receive a state charter for a college or university, the Medical Institute would be conveyed upon the consent of the mayor and council to the trustees of the newly-created school. Many citizens who had supported the Medical Institute also advocated the establishment of a municipal liberal arts college. In November, 1837, the city council approved an ordinance creating the Louisville Collegiate Institute, which opened the next year but failed to prosper as did its sister school. In 1840, the Collegiate Institute received a state charter under the name of the Louisville College. Some Louisvillians, especially opponents of the medical school, argued that according to the 1837 agreement, the trustees of the Louisville college should also govern the Medical Institute; furthermore, the medical professors should release a portion of their salaries to the city for the financial support of the two schools. Some resident physicians, who were opposed to the Medical Institute and ripe from the Flint controversy, allied themselves with the followers of the Louisville College. During the spring of 1840 the city council heard a motion in favor of the transfer, but the resolution was eventually withdrawn from the agenda and the issue remained unresolved. 17

In November, 1842, John Cleves Short commented to his 
brother Charles that "rumors of wars among the Louisville doctors" circulated among his Ohio neighbors. In August of that year supporters of the Louisville College had aligned with the disgruntled resident physicians and reopened the governance issue concerning the Louisville Medical Institute. At that time, the city council had heard a report from the chairman of a committee selected to investigate resolutions brought to the common council which provided for the transfer of the medical school to the Louisville College trustees. The report cited the professors and managers with mismanagement of the buildings, grounds, and equipment. Although this implied oversight of responsibilities ultimately resting with the dean of the school, who had been Dr. Short until the spring of 1841 , the pretentious report displayed the best interests of the opponents of the medical faculty. The account also indicated that each medical professor had made at least three thousand dollars the previous session, which were handsome wages for about four months work. In rebuttal, the medical faculty issued a counter-document which aided their political influence in the city council, where the resolutions were eventually defeated. 18

Despite the charges levied in the city council against the professors and managers of the Medical Institute, the school and its faculty continued to prosper. At the end of the 1844-1845 session, for example, Dr. Short had collected $\$ 3552$ in student fees, more than he had earned in any one session at Transylvania. Although no primary 
evidence indicates Short's direct involvment in the "wars among the Louisville doctors," he expressed general observations about the controversy. In 1844, he noted that the increase in the number of medical schools made medical education cheaper and more convenient for the aspiring physician. On the other hand, doctors discovered that securing a medical school charter usually required no more initiative than submitting an application to a state legislature. With the growth of proprietary medical schools, practioners, according to Short, "quit the business of making pills for that of making Doctors." Dr. Short wrote from experience. In Louisville he did not maintain a private practice. 19

The Louisville Medical Institute increasingly faced competition from regional medical schools, and, in one case, the proposed establishment of a local proprietary school threatened the success of the institute. In the spring of 1842, after his forced resignation, Joshua Barker Flint and several resident physicians organized the Academy of Medicine, designed to offer a comprehensive medical curriculum. Although the Academy never opened, Flint, his associates, and supporters of the Louisville College still sought to tap the financial resources of the city medical school. In November, 1845, they again advocated a proposed city resolution calling for the transfer of the Medical Institute to the trustees of the Louisville College. The resolution, furthermore, stipulated that medical students' matriculation and graduation fees would be used to aid the 
liberal arts college. The council adopted the resolution but the institute faculty argued that the 1837 agreement specified that if a university were established the Medical Institute would constitute one school within the municipal system of higher education, provided this met with the approval of the mayor and council. Writing to Uncle William, Charles registered his personal reaction to the pending resolution, which he charged was supported by "certain envious spirits and designing demagogues." He declared that the medical professors would not submit to the city legislation. 20

The medical institute professors indeed protested the city's threat to their domination of the administration and finances of the school. To circumvent the medical faculty, the city council in December, 1845, approved a proposed charter that would combine the Louisville College and the Louisville Medical Institute under one charter and one name, the University of Louisville. The council then requested the city's delegates to the Kentucky General Assembly to secure its passage. Against the appeals of the medical faculty, the legislature approved the university charter, which the governor signed on February 7, 1846. The Louisville Medical Institute experienced only one major change as a result of the new charter: on May 6, 1846, the Medical Institute became the Medical Department of the University of Louisville. The faculty maintained the right to elect its dean and other officers, make recommendations to the university's board of trustees, especially on faculty 
appointments, and retain student fees. The medical professors continued to share the general expenses of the school. Although they preferred their independence, under the circumstances Dr. Short and his colleagues were willing to carry on under the new charter. 21

Although the administrative control of the medical school was a major issue for Dr. Short and his colleagues, the instruction of students remained their chief activity during the session. Professor Short's lectures on materia medica probably changed little from his Transylvania days. After 1836, he supplemented his lectures with a botanical textbook, The Elements of Botany, written by his friend, correspondent, and Harvard University professor, Asa Gray. According to Louisville medical professor Henry Miller, Short's lecture style was "chaste, concise, and classical and his manner always grave and dignified." Miller also noted that his colleague always addressed his class from a prepared text which he read "with a good voice and correct emphasis." One Louisville medical student described the professor as "a fat, short, stoutly build man," who was "exceedingly methodical and precise," and often introduced a new lecture topic with "'and next on our list ..."'22

With the growth of class enrollments and in an age before nationally-accepted accreditation standards, Dr. Short expressed concern for the quality of education offered at the Louisville school. During examination week in 1848 , he admitted to Uncle William that some graduates were "not very well entitled to the honor," although he believed their 
instruction was comparable to any medical school in the country. This consideration and his growing dissatisfaction with teaching prompted Charles to complain that too many students completed the thesis requirement with "long dissertations, often in illegible characters, on subjects which they know little or nothing about." For example, the students' topics ranged from mental derangement and the influence of mind on matter to dyspepsia. Yet he was "compelled to read them!" 23

Early in November, 1845, Dr. Short delivered an introductory lecture on the duties of medical students. Based on his experiences as dean and professor, which required his contact with individual pupils, short offered fatherly advice to the young medicos. He outlined the students' responsibilities to their professors, to each other, and to the citizens of Louisville. Short regarded punctuality, attention, and studiousness as essential attributes of good student behavior. He also advised the students to observe acceptable classroom behavior, such as the removal of their hats in the lecture rooms. Rather than dress in the adopted fashion of the day, Dr. Short recommended a "loose plain, and cheap box-coat, of some neutral color, ... cloth or fur cap in preference to a hat, and a stout pair of thick-soled boots, with under-garments of warm and comfortable materials." The professor encouraged the aspiring physicians to cultivate friendships among themselves and admitted that while the medical school professors enjoyed such goodwill, too often faculty members 
provided "the unhallowed example of envy, jealousy, and detraction." Short paid tribute to the city of Louisville for its financial support of the medical school and called for the students' cooperation in the maintenance of an orderly, decent community. Finally, the professor warned the young men not to spend too much time in the company of women, to observe the Sabbath, attend church, and read appropriate books, including the Bible. 24

Charles' dissatisfaction with his teaching seems to have increased with each school session. He disliked living in industrial Louisville where he complained of "inhaling coal soot--wading through its filthy streets, or being stiffled [sic] with its dirt and ashes." Summer days in the city were especially hot and dirty. In July, 1841, Charles paid his brother Cleves $\$ 5000$ for 140 acres where he planned to build a summer home. The tract, carved from his brother's estate, Shorthill, fronted the ohio River about twelve miles below Cincinnati. During the next two years, Charles contracted with local ohio laborers for the construction of a family dwelling, cellar, smokehouse, barn, and poultry and ice houses. At the end of the 1843 school term, the short family traveled twelve hours via steamboat to "Fernbank," named by Dr. Short for the profusion of ferns on the wooded grounds. The family spent the next three summers at their Ohio house, where they enjoyed a leisurely rural lifestyle and the companionship of relatives. Charles took particular pleasure in his garden and exploring the botany of the area. He remarked that, if possible, he would make Fernbank his 
permanent home. In 1847, however, Charles sold the property to his brother because the family found it inconvenient, expensive to maintain, and an imposition to live without the services of slaves. 25

The composition of the Short family changed during the 1840s. In 1841, Mary, the eldest daughter, married William Allan Richardson, a Louisvillian who worked at the Northern Bank of Kentucky. At the age of forty-eight Mary Churchill Short gave birth on January 11, 1842, to the couple's last child, Alice. In 1843, the Short's only son, William, graduated from Centre College in Danville, Kentucky, and three years later he married his second cousin, Catherine Matilda Strader. During the decade, at least two Short daughters, Jane and Sarah, attended the Steubenville (Ohio) Female Seminary. In 1847 , daughter Jane married James Russell Butler, who was graduated from the University of Louisville Medical Department in 1850. In 1849, Dr. Short who was fifty-five years old, had three children living at home: Sarah (21), Lucy (18), and Alice (7).26

Private schools, family trips, a summer cottage, family weddings, and a more spacious house were signs of Charles' economic success. During the spring of 1842 , the Short family moved from their house on Jefferson Street to a larger rented dwelling on the southeast corner of Third and Chestnut Streets. In 1845 Charles and Mary, accompanied by son William and daughters Jane, Sally, and three-year-old Alice, journeyed on the steamboat Sultana down the Ohio and Mississippi Rivers to New Orleans. The four week trip, 
purportedly for Mary's health, was Charles' only vacation in the deep South, whereas other leisure trips were in directions to the north and northeast of Kentucky. The family stayed a few days in New Orleans where they lodged at the St. Charles Hotel. One letter from Charles to his brother provided an interesting commentary on southern plantations. He noted that after Natchez, Mississippi, the cotton plantations were replaced with older sugar plantations. Planters' houses were large, two story dwellings with steep roofs and adorned with a porch or veranda. Oak trees, plants, and flowers were common. He observed that the "negro houses" reminded him "of the long lines of whitened cottages, so often seen at our best watering places." Although he remarked that each plantation's slave quarters were different, most had small gardens and poultry houses. Charles suggested that the condition of the slave houses might signify the personal disposition of the owner. 27

The institute's success and Charles' share of the profits provided the shorts with the means of a comfortable lifestyle. In March, 1846, moreover, Charles learned that he and his brother would inherit Uncle William's estate. That year, the eighty-seven-year-old bachelor transferred his stocks and other property to his nephews and retained about a nine thousand dollar annuity for his living expenses. After their initial correspondence with Uncle William, the Short brothers estimated their inheritance to value at least one million dollars. In 1847, Uncle William conveyed the title 
to his Philadelphia house to the nephews. William Short, a lawyer, made the bequests before his death hoping to prevent the depreciation of his estate through such legalities as inheritance taxes. 28

For the next several years, Charles, his brother, Cleves, and Uncle Wiliam's agent in Philadelphia, Samuel H. Carpenter, attended to the details of the inheritance. In December, 1848, for example, William transferred all his Kentucky land to Charles. William instructed that the stocks be equally divided between the two heirs and that new certificates be issued to each one. By 1848 , this procedure had been completed for the stock of western enterprises, which included the Louisville and Portland Canal, the Bank of Louisville, the Northern Bank of Kentucky, and the Ohio Life

and Trust Company. By power of attorney, Carpenter administered stock of eastern concerns. The brothers' ownership of western securities consequently involved them in the business of the community. In 1848, the stockholders of the Bank of Louisville elected Dr. Short a bank director and in 1849 he served as chairman of the board of directors of the Louisville and Portland Canal Company. 29

In August, 1846 , Charles reported to Uncle William that he considered investing his newly-acquired stock dividends in the purchase of a farm for his son William, who had recently married. The next month, Dr. Short negotiated a purchase agreement for the 230 acre Hayfield estate, located about five miles east of Louisville near the Bardstown Turnpike. George Hancock, a native of Virginia who emigrated 
to Kentucky around 1819, had bought the farm in the mid-1830s and commissioned the construction of the elegant main house of Greek revival design. Dr. Short claimed that Hancock, who had christened the estate "Hayfield," found himself impoverished after the construction of the dwelling. On January 20, 1847, Dr. Short paid his first installment of $\$ 15,000$ toward the $\$ 38,000$ total purchase price. Shortly thereafter, son William and his wife Matilda moved to the country estate, which Charles described as "one of the most desirable places in the county, or indeed in the state."30 During the medical session, Dr. and Mrs. Short lived in the city. The remainder of the year, they stayed at Hayfield, only a forty-minute carriage ride to the outskirts of Louisville. The estate's location was also conveniently located to the city's port, where their farm products could be shipped to sale to other localities. At Hayfield, the Shorts operated a dairy and market garden. Dr. Short especially took interest in his "choice little flock of about fifty Southdowns." During his first spring at Hayfield, Charles commenced work on a garden and developed an orchard. That summer, he hired a German gardener to help him with horticultural projects. 31

Dr. Short continued to devote his leisure hours to the study of botany. At commodious Hayfield, he set up a botanical laboratory, which included a work table and a large, mahogany cabinet for the storage of dried plants. During these years, he had maintained and enlarged his roster of correspondents, to whom he had provided preserved plant 
specimens; continued research for his proposed book, the Flora of Kentucky; patronized botanical expeditions; and received recognition for his contribution to American science. 32

During Dr. Short's day, American botanists' main activity focused on the identification and classifiction of the country's flora. Field work for the botanist included searching for unknown plants and identifying the flora of a region. The botanist carried tools for excavating and collecting plants, such as a metal case called a vasculum, and a small trowel or knife, in addition to blotter paper and a portable press to preserve plants for later study or exchanges with other botanists. Dried plants were kept in a herbarium where specimens were arranged for reference and sometimes glued to paper for easier access. Botanists in the settled sections of the country became experts in their respective local flora and through plant exchanges they supplemented their collections with specimens from other regions. 33

From the outset of the Lewis and Clark Expedition in 1803 , to the Pacific railroad surveys in the $1850 \mathrm{~s}$, the federal government supported the exploration of the West, which resulted in many botanical discoveries. West Point military men trained in engineering and science led government expeditions through unfamiliar regions from the Mississippi River west to California and north from the Mexican boundary to the Oregon Territory. These topographical experts not only provided information of 
interest to prospective settlers, which encouraged the spirit of manifest destiny, but they also collected specimens of flora and fauna, in addition to accumulating other scientific data. Their gatherings eventually became research collections maintained by private institutions, the Smithsonian Institution, or individual scientists. Citizen-botanists frequently traveled. with these government expeditions.and oftentimes financed their trips by offering their prospective collections for sale. 34

In addition to a herbarium, botanical publications were essential reference aids for the taxonomist. After gathering unknown plants, a botanist would consult scientific literature for descriptions and classifications of known plants. If the botanist suspected the discovery of a new genus or species, he would classify the plant or perhaps, send the plant specimen to other botanists for further study and eventual classification. In the $1820 \mathrm{~s}$ and $1830 \mathrm{~s}$, Dr. Short became the expert on and supplier of western plants while other botanists performed the same activity for their respective localities. Some botanists, including short, described their findings in correspondence which accompanied their plants. Classifications were eventually published in various outlets, such as privately-sponsored books or journal articles. Dr. Short, for example, published his catalogue of Kentucky plants in his schools' journals. 35

By the $1830 \mathrm{~s}$, two eastern botanists had emerged as leaders of the taxonomy of American flora. Since 1827, John Torrey had served as professor of chemistry at the. New York 
College of Physicians and Surgeons and professor of natural history at the College of New Jersey (later Princeton). By 1830, he had published a catalog of plants of New York City and its environs, books on the flora of the northern and middle states, and reports on plants gathered by botanists attached to government surveying and exploring expeditions. One of his students, Asa Gray, who like his mentor had received a medical degree, soon abandoned the practice of medicine to pursue botany as a career. From 1831 to 1835 , Gray served as Torrey's assistant and then curator of the New York Lyceum of Natural History, of which Torrey was a founding member. Gray's North American Gramineae and Cyperaceae $(1834-1835)$ and Elements of Botany (1836) demonstrated his intellectual ability and botanical expertise and assured his distinction among the corps of American and European botanists. 36

While on the faculty at Transylvania, Short had established correspondence and plant exchanges with John Torrey and Asa Gray. In 1831, Torrey had solicited Dr. Short as a supplier of western flora and in 1835 Asa Gray asked to be included on Professor Short's plant distribution list. Torrey and Gray's herbaria became depositories for plants from every settled area and region of exploration in the United states. They were asked to provide taxonomic data to American and European botanists in addition to those who merely engaged in gathering and classifying plants as a hobby. Torrey and Gray benefited from their proximity to Boston and Philadelphia, both recognized scientific centers 
of the country, and the homes of the American Philosophical Society, the Academy of Natural Sciences of Philadelphia, and the Academy of Arts and Sciences in Boston. These learned societies received plants from the network of botanists across the country and housed the herbaria of numerous deceased eminent naturalists. Drs. Torrey and Gray also corresponded and exchanged plant specimens with leading European botanists, such as William Jackson Hooker, Regius Professor at the University of Edinburgh and later director of the Royal Botanic Gardens: at $\mathrm{Kew}$, and the Genevan botanists Alphonse De Candolle and his father Augustin-Pyramus De Candolle. Eventually, these Europeans in addition to others, such as Francois Brisseau De Mirbel, Joachim Steetz, Christian Munch, and C.F. Meisner, also came into contact with Dr. Short. They were familiar with herbaria of American flora collected during seventeenth and eighteenth-century European explorations of the North American continent. With their comprehensive resources, Drs. Torrey and Gray ambitiously set out to write a Flora of North America based on the natural system of plant classification. 37

Europeans had written earlier accounts on the plants of North America, but John Torrey and Asa Gray's book, eventually published in several parts between 1838 and 1843 , was the first account on the subject by native American botanists. In the autumn of 1838, Asa Gray began a year's leave of absence from his professorship at the newly-established University of Michigan at Ann Arbor. He 
went to Europe to purchase books for the new university library and to study original specimens of American flora in selected herbaria, in preparation for the second part of the Flora of North America. After twenty-one days on the packet Philadelphia, Gray arrived in England and journeyed to Edinburgh, where he surveyed the herbarium of William Hooker, author of Flora Boreali-Americana (1828-1840). During the remainder of his leave, Gray continued his visits to the herbaria on the continent. 38

In March, 1839, Dr. Gray arrived in Paris and stayed for almost a month surveying and studying the herbarium of André Michaux at the Museum d'Histoire Naturelle. Michaux, a botanist sponsored by King Louis XVI, had spent the years 1785 to 1796 studying the flora of North America. For the first year he lived in New Jersey and explored, collected, and sent home various botanical specimens from the middle Atlantic states. Finding the harsh winter climate detrimental to this botanical garden, Michaux moved to a plantation near Charleston, South Carolina. For ten years he persistently explored the southern regions of the United States, the Bahama Islands, and even traveled as far north as Hudson Bay. From Michaux's collection the Paris botanist, Louis Claude Marie Richard had compiled one of the first volumes on the flora of North America, Flora Boreali-Americana (1820).39

During the last week of his month's work with the Michaux collection, Dr. Gray surveyed the plants that had not been identified by the collector as to genus and species. 
Gray noticed one plant specimen, not in flower, which Michaux had discovered in the high mountains of the Carolinas. Although the plant resembled the Galax genus, Dr. Gray was confident that he had discovered a new genus and claimed the traditional priviledge of naming the plant. He christened the plant Shortia galacifolia in honor of his friend and botanical correspondent Dr. Charles Wilkins Short of Kentucky. Gray reasoned that Short's home. state was not far from the native habitat of the plant, a conclusion which demonstrated some ignorance of the geography of the southern highlands. In writing to John. Torrey, Gray asked that Dr. Short be informed of the new genus and be charged to journey to the Carolinas during the next summer to study the plant in flower. 40

In 1840 Gray announced his discovery of the unknown plant, which he called Shortia galacifolia. Late the next year he wrote again in more detail of his discovery and the naming of the plant Shortia galacifolia and the establishment of the genus Shortia. He published both announcements in The American Journal of Science and Arts, a common outlet for scientific communications of that day and a periodical also known as "Silliman's Journal" after the editor, Benjamin Silliman. Eventually, such announcements of botanical discoveries and classifications were compiled for inclusion in standard botanical guides such as Torrey and Gray's Flora of North America. In his article, Gray dedicated the genus Shortia to Dr. Charles Wilkins Short, "whose attainment and eminent services in North American botany" were "well 
known and appreciated at home and abroad." 41

When Gray published his discovery and naming of Shortia galacifolia, only Michaux had seen and reported its existence in the natural habitat. The search for the rediscovery of Shortia began in 1839 after Dr. Gray noticed the plant among the unnamed specimens of the Michaux collection. In 1839 , Dr. Short had been unable to accept the challenge to journey to the Carolina mountains, but he encouraged Moses A. Curtis, a naturalist and Episcopalian minister, who made summer missionary tours in the North Carolina mountains, to hunt for the Michaux plant. Another explorer, Samuel B. Buckley, looked for Shortia without success. After his European trip, Asa Gray himself took up the search in the North Carolina mountains. Using Michaux's journal, he followed the Frenchman's route to Grandfather Mountain, but failed to locate Shortia. Although Dr. Gray remained optimistic' that Shortia would be found, he offered to name another plant after short. Torrey, thinking short to be disappointed over the lost Shortia, considered naming a Kentucky plant after him. He warned Short that Thomas Nuttall an Englishman and friend of Short's, who had made extensive botanical explorations of the United States and the trans-Mississippi west, might honor him with "some racky little California weed" if short did not take precautions. 42 Although Dr. Short and Dr. Gray never met, their common profession and interests provided them with reasons to correspond: Eventually, they became personal friends. Both men were medical doctors, botanists, college professors, 
collectors, and preservers of plant specimens. For the Flora of North America Gray and Torrey relied on Dr. Short for plant specimens and taxonomic information about flora indigenous to Kentucky and its vicinity. 43

In $1842, \mathrm{Dr}$. Gray assumed the Fisher Professorship of Natural History at Harvard University. The position carried duties relating only to botany, a distinction which ultimately signified the recognition of botany as a field of science rather than an area of the antiquated study of natural history. Gray arrived in Cambridge with a valuable, extensive herbarium, but he inherited a neglected botanical garden. Both were important research and teaching resources for a professor of botany. Dr. Gray's botanical correspondents became suppliers for the Cambridge garden. Dr. Short provided him with plants, roots, and seeds of Kentucky and southern Ohio plants in addition to naming southern and western persons who would favor Gray with similar botanical gifts. Short's list included Dr. Charles E. Lavender, Hamilton, Alabama; Dr. Josiah Hale, Alexandria, Louisiana; William Starling Sullivant, Columbus, Ohio; Increase Allan Lapham, Milwaukee, Wisconsin; and Dr. George Engelmann, St. Louis, Missouri. 44

In 1841, Dr. Short had asked George Engelmann to exchange dried plants and correspondence concerning botanical news and information. A native of Germany, Engelmann took the M.D. degree in 1831 from the University of Wurzburg. During the next year he immigrated to the United States and settled in St. Louis, Missouri, where he established a 
medical practice. The Missouri town provided Engelmann with a strategic geographical location for botanical study. Many exploring parties of the $1840 \mathrm{~s}$ and $1850 \mathrm{~s}$ set out from St. Louis, where they followed trails blazed by fur traders, military men, and other frontiersmen. They represented a new breed of naturalists, who were trained specialists in botany rather than amateurs interested in natural history. By the $1840 \mathrm{~s}$, a new scientific community emerged in the United States, which included these explorers who fed information to other botanists, such as Engelmann, Torrey, and Gray. 45

In 1843 Short wrote Engelmann of his desire to be a subscriber to the collections of Ferdinand Jacob Lindheimer, a German immigrant who lived in Texas. Engelmann had encouraged Lindheimer to pursue the study of Texas plants and from 1845 to 1850 Engelmann and Asa Gray published in two parts the Plantae Lindheimerianae, a description of the Texan's plant discoveries. That year, Dr. Short asked Engelmann to help him purchase plants collected for him from the Rocky Mountains, Oregon, and California. In 1848, he offered to send Dr. Engelmann money to secure a complete set of Mexican plants gathered by August Fendler, a Prussian who came to the United States in 1836, and lived as a botanical frontiersman. While short patronized botanical explorations, he supplemented his herbarium with flora of the American West. 46

For many years, Dr. Short had planned to write a book on the botany of Kentucky, but his enthusiasm for the project waned with the realization of high publication costs and an 
anticipation of a small number of prospective purchasers. In August, 1838 , before his move to Lexington, Charles reported to his Uncle william that he had decided to discontinue work on the Flora of Kentucky, although he had written to Professor Hooker about the option of publishing the book at a lower price in Great Britain. Hooker had offered to oversee and publicize the work, which Charles planned to illustrate with colored engravings. Later, while in Louisville, the site of untapped botanical resources, Dr. Short displayed renewed interest in his Flora. In 1843, he continued to collect specimens to make the book "as perfect as possible." At this juncture, he suggested that his Flora could be a section in a state-funded geological and natural history survey report. Finally, in 1846 , after receiving news of his inheritance, Charles realized that financing the book was no longer a stumbling block and again voiced his commitment to the project. 47

Unfortunately for himself and the scientific community, Dr. Short never published a Flora of Kentucky. After 1846, he had time and money to write and publish the book, but he chose to devote his energies to the perfection of his herbarium through plant exchanges and subscriptions in addition to maintaining his contact with other botanists through correspondence. Perhaps Short realized that his research would be available for his successors and took pleasure in fellow botanists' recognition of his work. Short also noted that he had the "satisfaction frequently of seeing my name and labours in some of the most able and elegant 
works of G. Britain." He sent dried plants to botanical correspondents in all sectors of the United States and to England, France, Switzerland, and Germany. Short's friend and correspondent, William Darlington of West Chester, Pennsylvania, knew of Dr. Short's contributions to European botanists and he predicted that Short probably possessed "one of the best Herbariums in the U. States" as a result of his exchanges. In 1842 , Dr. Short commented that his herbarium contained more European plants than those of American origin. 48

In 1826 Dr. William Darlington had published Flora Cestrica, a book on the botany of his native area. In 1837, Dr. Short reviewed Darlington's work in the Transylvania Journal. In his complimentary essay, Short recognized the academic qualifications of the author, who like himself had graduated from the University of Pennsylvania medical school where he had studied under Benjamin Smith Barton. Dr. Short praised Darlington for his botanical work and influence in the advancement of science of his native locality and country. He defended the author's use of the Linnaean system of classification, in which plants were arranged by their number of sexual parts. Short and Darlington supported the argument that the Linnaean, or artificial system, aided the amateur botanists in the study of plant structures, functions, and natural affinities. 49 During his teaching years in Louisville, Dr. Short contributed only two major articles to botanical literature. In 1840 he published in the Western Journal of Medicine and 
Surgery the last supplement to his "Catalogue of the Plants of Kentucky," and in 1845 Short's, "Observations on the Botany of Illinois," appeared in the same journal. In late summer and autumn of 1837 , Dr. Short and his brother had journeyed in a covered wagon through Indiana and Illinois searching for prospective land purchases, which they planned to buy with $\$ 5000$ their Uncle william had given them to invest in western lands. There itinerary included the Indiana towns of Indianapolis and Terre Haute, where they crossed the Wabash River into Illinois. Then they proceeded southward from Peoria toward Paris, Urbana, and Bloomington, and finally toured the southern region of the state. In his article, Professor Short described the topographical features of the region and included a plant catalogue from his travel journal. Overall, Short reported his disappointment in the flora of the Illinois prairie, which was not abundant with a variety of plants. 50

Dr. Short claimed botany as his avocation, whereas teaching school was his job. While preparing his 1847 valedictory address, Charles confided to his brother that he was weary of teaching and would rather deliver a farewell speech to the faculty and school. The cautious short determined that although he wanted to be a "free man," his forthcoming payments on Hayfield prevented him from resigning. Dr. Short avoided owing money to anyone probably because he feared guilt from association stemming from his father's reputation as a debtor. Dr. Short returned to the Medical Department the next session, when in January, 1848 , 
he reported an enrollment of 406 students from whom he had collected around five thousand dollars. The professor commented, however, that he would rather plant trees and shrubbery at Fernbank or Hayfield than sit and accept students' fees. 51

The continued success and prosperity of the Medical Department also influenced Dr. Short's commitment to his professorship. In 1848 , six years after their unsuccessful attempt to establish a local rival medical school, opponents of the Medical Department of: the University of Louisville, led by Joshua Barker Flint, petitioned the state legislature to charter another medical school in Louisville. In a letter to Uncle William, Charles described these local physicians as "malcontent Doctors, who embued with a full portion of the Agrarian Democracy of the day, think themselves wronged, because we are in, and they are out." The Kentucky School of Medicine received a charter and in 1850 opened in Louisville with Flint as dean of the faculty. 52

By June, 1848, Dr. Short had given serious considerations to his retirment from the medical faculty; his only reservation, however, concerned Uncle William. Charles feared that his uncle would think he was lazy and content to live on his inheritance. On the contrary, Charles defended his years of arduous teaching and explained that he was "tired to death of the business." Before classes started in late autumn of 1848 , Charles suffered an illness which continued to plague him after lectures began. Poor health was also a contributing factor in his decision to resign. By 
December, Charles was distressed with his duties at the medical school and wrote that each day he was so busy with class preparations and lectures that he had little time "to attend to the now naturals." 53

On June 18,1849 , the University of Louisville Board of Trustees accepted Dr. Short's resignation, elected him professor emeritus, and appointed Dr. Lewis Rogers, a University of Pennsylvania professor, to succeed Short in the chair of materia medica and therapeutics. The change of the title of the position from materia medica and medical botany to materia medica and therapeutics reflected a contemporary course title. Earlier in the spring the trustees had accepted the resignation of Dr. Daniel Drake and had forced Dr. Caldwell to take an early retirement. Dr. Short thought Professor Caldwell was a remarkable person, who unlike himself, enjoyed teaching. "Poor old man, he would have lectured to the last, and died a-lecturing, if he had been allowed to do so," commented Short. The resignations of Drake, Caldwell, and Short marked the end of an era in the history of the young medical school. Professor Lunsford P. Yandell, Sr. later paid tribute to his colleague Short, who "possessed qualities which rendered him a most valuable officer. His high scientific attainments, the soundness of his judgment, his dignity and urbanity of manners, his amiable temper, and blameless life, added character and weight to the institution." 54

When Dr. Short retired in 1849 , he had served eleven years on the Louisville faculty and twenty-four years as a 
medical professor. His contributions as a teacher and administrator were significant in the history of pioneer medical education in Kentucky and the West. His profession, however, had afforded him little gratification, except in monetary rewards. Although he had often complained abut teaching and the personal and political conflicts associated with the position, his enthusiasm for botany seldom waned. Louisville had provided new botanical territory. He had met the challenge with vigor and had collected abundant plant specimens for his study, preservation, and exchanges with friends and institutions. During these years, the distinguished American botanist Asa Gray named a plant genus after Dr. Short and thereby preserved an everlasting honor to the Kentucky botanist. Dr. Short, fifty-five years old, looked forward to his retirement at Hayfield, where he could continue to augment his plant collections, pursue horticultural pleasures, and devote many hours to his correspondence and family. 


\section{NOTES TO CHAPTER IV}

${ }^{1}$ Charles Wilkins Short to William Short, August 27 , 1838, File 21, Charles Wilkins Short Papers, Filson Club, Louisville, Kentucky (hereinafter SPFC).

${ }^{2}$ W. Short to C.W. Short, January 9 , 1837, File 7 , SPFC; C.W. Short to W. Short, June 24,1838 , July 10, 1838 , File 21, SPFC; W. Short to C.W. Short; July 3, 1838, File 8 , SPFC.

3C.W. Short to W. Short, July 29, 1838, File 21, SPFC; C.W. Short to W. Short, September 11, 1838, Charles Wilkins Short Papers, Southern Historical Collection, University of North Carolina, Chapel Hill, North Carolina (hereinafter SPSHC).

${ }^{4}$ C.W. Short to W. Short, September 11, 1838, SPSHC; John Cleves Short to C.W. Short, November 1, 1837, July 16, 1839, Short, Harrison, and Symmes Family Papers, Library of Congress, Washington, D.C., microfilm in the Filson Club (hereinafter SHSLC); G. Collins, The Louisville City Directory for 1841 (Louisville, Ky.: Henkle, Logan \& Co., 1841), p. 93; C.W. Short to W. Short, June 24, 1838, File 21, SPEC; C.W. Short and Mary Churchill Richardson, "A Chronological Record of the Families of Charles Wilkins Short and Mary Henry Churchill," 1843, 1879, p. 16, SPFC.

5 Lexington Intelligencer, August $31,1838, \mathrm{p}$. 3 ; C.W. Short to W. Short, September 23, 1838 , October 11, 1838 , October 28, 1838, File 21, SPFC; Lunsford P. Yandell to Susan Yandell, October 6, 1838, Yandell Family Papers, Filson Club.

6 George H. Yater, Two Hundred Years at the Falls of the Ohio: A History of Louisville and Jefferson County (Louisville, Ky.: The Heritage Corporation, 1979), pp. $55-60$.

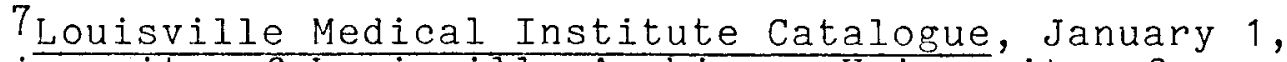
1839, University of Louisville Archives, University of Louisville, Louisville, Kentucky (hereinafter ULA); Kentucky Writers' Project of the Works Projects Administration, A Centennial History of the University of Louisville (Louisville, Ky.: University of Louisville, 1939), pp. $48-49$.

\footnotetext{
${ }^{8}$ Louisville Medical Institute Catalogue, January 1 ,

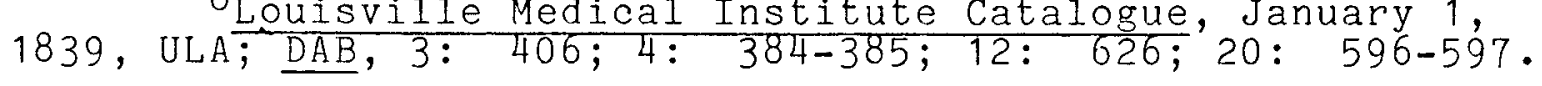
9W. Short to C.W. Short, November 18, 1839, File 9,
} 
SPFC; C.W. Short to W. Short, March 8, 1840, File 23, SPFC.

${ }^{10}$ Louisville Medical Institute Catalogue, 1839 , ULA; Lunsford P. Yandell, History of the University of Louisville: An Introductory Lecture (Louisville, Ky.: Prentice and Weissinger, 1852), pp. 15-17; William Frederick Norwood, Medical Education in the United States before the Civil War (New York: Arno Press, 1971; originally published 1941), pp. 304-328; 353-376; William G. Rothstein, American Physicians in the Nineteenth Century: From Sects to Science (Baltimore: Johns Hopkins University Press, 1972), pp. 93-100; C.W. Short to W. Short, March 10, 1839, File 22, SPFC; DAB, 5: 478-479.

11 J.C. Short to C.W. Short, July 26, 1839, SHSLC.

$12 \mathrm{C} . \mathrm{W}$. Short to W. Short, September 12, 1839, October 13, 1839, File 22, SPFC; Emmet Field Horine, Daniel Drake (1785-1852): Pioneer Physician of the Midwest (Phildelphia: University of Pennsylvania Press, 1961), p. 322; DAB, 5: $426-427$.

13Louisville Medical Institute Catalogue, 1839-1840, ULA; C.W. Short to W. Short, November 24, 1839, File 22, SPFC; C.W. Short to W. Short, February 6, 1840, File 23, SPFC; Centennial History, pp. 50-51; Erwin H. Ackerknecht, A Short History of Medicine (New York: Ronald Press, 1955), pp. 146-147.

14 Medical Historical Research Project of the Works Projects Administration, Medicine and Its Development in Kentucky (Louisville, Ky.: Standard Printing Co., 1940), pp. 102-103; C.W. Short, "A Fourth Supplementary Catalogue of the Plants of Kentucky," The Western Journal of Medicine and Surgery 2 (October 1840): 283-288; C.W. Short, "Observations on the Botany of Illinois, more especially in reference to the Autumnal Flora of the Prairies," The Western Journal of Medicine and Surgery 3 (March 1845): 185-198.

15Louisville Journal, May 21,1840, p. 2; May 22, 1840, p. 1, May 30, 1840, p. 2; Louisville Public Advertiser, May 28,1840 , p. 2, June 5,1840 , p. 2; Horine, Daniel Drake, pp. 334-335; William A. McDowell, Meeting of the Medical Faculty of Louisville (Louisville, Ky.: n.p., 1840); C.W. Short to W. Short, May 24, 1840, File 23, SPFC.

$16 \mathrm{C} . \mathrm{W}$. Short to W. Short, May 24, 1840, File 23, SPFC; DAB, 8: 18-20; Samuel D. Gross, Autobiography 2 vols. (Phildelphia: Georgie Barrie, 1887), $1: 89-90$.

17 Louisville, Kentucky, Minutes of the Common Council, April 24, 1837, 10: 167-169; November 27, 1837, 10: 370-371; April 27, 1840, 11: 500-501; May 18, 1840, 12: 16-17; ULA; Louisville Public Advertiser, June 3, 1840, p. 2 ; Louisville Journal, May 20, 1840, p. 2, June 13, 1840, p. 2 ; Centennial History, pp. 13-16, 51-53. 
18 J.C. Short to C.W. Short, November 3, 1842, SHSLC; Louisville, Kentucky, Minutes of the Common Council, August 8, 1842, 13: 227-238, ULA; Some Account of the Faculty of the Louisville Medical Institute. Supplementary to an Anonymous Pamphlet by the Same, Entitled "Some Account of the Institute" (Louisville, Ky.: The City Gazette, 1842).

${ }^{19}$ C.W. Short to W. Short, February 19, 1844, File 27, SPFC; C.W. Short to W. Short, March 15, 1845, File 28, SPFC.

20 Norwood, Medical Education in the United States before the Civil War, pp. 297-318; Horine, Daniel Drake, p. 336; Louisville, Kentucky, Minutes of the Common Council, November 29, 1845, 15: 60, ULA; C.W. Short to W. Short, December 3, 1845, File 28, SPFC; C.W. Short to W. Short, January 18,1846, File 29 , SPFC.

${ }^{21}$ Louisville, Kentucky, Minutes of the Common Council, December 30, 1845, 15: 82-84, ULA; Centennial History, pp. 51-59.

${ }^{22}$ C.W. Short to Asa Gray, December 26, 1842, Asa Gray Papers, Gray Herbarium Library, Harvard University, Cambridge Massachusetts (hereinafter AGHU); Robert Peter, The History of the Medical Department of Transylvania University (Louisville, Ky.: John P. Morton and Co., 1905), pp. 78-82; C.A. Hentz, "Autobiography," pp. 65-66, Southern Historical Collection, University of North Carolina, Chapel Hill.

23 C.W. Short to W. Short, March 2, 1848 , File 31, SPFC; C.W. Short to J.C. Short, February 16, 1848, SHSLC; Louisville Medical Institute Catalogue, 1843-1844, pp . 8-10.

${ }^{24}$ Charles Wilkins Short, Duties of Medical Students During Attendance on Lectures (Louisville, Ky.: Morton \& Griswold, 1845).

${ }^{25}$ C.W. Short to J.C. Short, February 13, 1844 , SHSLC; Cost of Fernbank and Improvements Thereon, File 137, SPFC; C.W. Short to W. Short, November 20, 1842, File 25, SPFC; C.W. Short to W. Short, April 26, 1843, File 26, SPFC; C.W. Short to W. Short, September 7, 1844, File 27, SPFC; C.W. Short to W. Short, October 15, 1845, File 28, SPFC; C.W. Short to W. Short, september 23, 1847, File 30, SPFC.

${ }^{26} \mathrm{C} . \mathrm{W}$. Short and Richardson, "A Chronological Record of the Families of Charles Wilkins Short and Mary Henry Churchill," pp. 11-12, 25-27, SPFC; C.W. Short to W. Short, October 30, 1843, File 26, SPFC; Lucy S. Henry to Mary Short, January 12, 1842, File 130, SPFC; Sally and Jane Short to C.W. and Mary Short, June 24, (n.y.), Reid Collection, SPFC; Charles C. Beatty to C.W. Short, September 10, 1841, File 69, SPFC.

$27_{G}$. Collins, The Louisville Directory for the Years 
1843-1844 (Louisville, Ky.: A.S. Tilden Printer, 1843), p. 137; C.W. Short to W. Short, July 7, 1842, File: 25, SPFC; C.W. Short to J.C. Short, March 30, 1845, SHSLC; C.W. Short to W. Short, April 1, 1845, File 28, SPFC; Mary Short to Mary Richardson, April 3, 1845, SPSHC; C.W. Short to J.C. Short, April 9, 1845, April 23, 1845, SHSLC.

28 J.C. Short to C.W. Short, Apri1 9, 1839, SHSLC; William Short, Jr. to C.W. Short, March 24, 1846, SHSLC; C.W. Short to J.C. Short, May 14, 1846, SHSLC.

29 Letter of Attorney, W. Short to Samuel Younglove and Samuel B. Younglove, 1840, File 92, SPFC; C.W. Short to W. Short, December 21, 1846, File 29, SPFC; C.W. Short to W. Short, January 30, 1848, January 10, 1849, SHSLC; J.C. Short and C.W. Short to Samuel H. Carpenter, July 4, 1846, File 99, SPFC.

${ }^{30} \mathrm{C}$. W. Short to W. Short, August 24,1846 , September 10, 1846, File 29, SPFC; C.W. Short to W. Short, July 22, 1848, File 31, SPFC; C.W. Short to J.C. Short, January 20 , 1847, October 24, 1847, SHSLC; National Register of Historic Places Inventory, Nomination Form for Hayfield, April 22 , 1980, Louisville Landmarks Commission, Louisville, Kentucky.

31 W. Short, Jr. to J.C. Short, November 7,1847 , SHSLC; C.W. Short to J.C. Short, December 13, 1847, August 2, 1847, August 4, 1847, May 11, 13, 1851, SHSLC; C.W. Short to J.C. Short, January 6, 1855, Reid Collection, SPFC.

$32 \mathrm{C} . \mathrm{W}$. Short and Richardson, "A Chronological Record of the Families of Charles Wilkins Short and Mary Henry Churchill," p. 169, SPFC; J.R. Massey to the author, May 27 , 1982. The botanical work table is now located in the Department of Botany, University of North Carolina and the cabinet is on exhibit at Locust Grove, Louisville, Kentucky.

33 Charles W. Short, "Instruction for the Gathering and Preservation of Plants for Herbaria; in a Letter to a Young Botanist," The Transylvania Journal of Medicine and the Associate Sciences 6 (January-March 1833): 8 [sic], 61-74.

34 A. Hunter Dupree, Science in the Federal Government (Cambridge, Massachusetts: The Belknap Press of Harvard University, 1957), pp. 91-95.

35 A. Hunter Dupree, Asa Gray, 1810-1888 (New York: Atheneum, 1968; originally published 1959), p. 24.

36 Andrew Denny Rodgers, III, John Torrey: A Story of North American Botany (Princeton: Princeton University Press, 1942), pp. 22, 46-53, 78-79, 87-94; Dupree, Asa Gray, pp. 56, 125; DSB, 5: 511-514; 13: $432-433$.

37 C.W. Short to John Torrey, John Torrey Collection, 
Academy of Natural Sciences of Philadelphia, Philadelphia, Pennsylvania (hereinafter ANSP); Dupree, Asa Gray, pp. 13-29, 74-92; DSB, 3: 42-45;6: 492-495; 9: 418-419.

38 Torrey to C.W. Short, June 30,1839 , SPFC; Dupree, Asa Gray, pp. 74-75, 82-92.

39 Dupree, Asa Gray, pp. 84-86; DSB, 9: 365-366; Harry Baker Humphrey, Makers of North American Botany (New York: Ronald Press, Co., 1961), pp. 174-176.

40 Torrey to C.W. Short, June 30,1839 , Botanical Correspondence, vol. 3, SPFC; Jane Loring Gray, ed., The Letters of Asa Gray, 2 vols. (New York: Lenox Hall, 1973; originally published 1893), 1: 177-179; Torrey to C.W. Short, July'12, 1839, Botanical Correspondence, vol. 3, SPFC.

${ }^{41}$ Asa Gray, "Review of De Candolle's Prodromus," American Journal of Science and Arts 39, 1st ser. (April-June 1840): 169; Gray, "Notes of a Botanical Excursion to the Mountains of North Carolina, etc.; with Some Remarks on the Botany of the Higher Alleghany Mountains, (in a letter to Sir William J. Hooker)," The American Journal of Science and Arts, 1st ser. 41 (October-December 1841): 48.

42 C.W. Short to Torrey, July 21,1839 , John Torrey Papers, New York Botanical Garden Library, Bronx, New York (hereinafter NYBG); Moses A. Curtis to C.W. Short, August 1, 1839, August 19, 1839, November 20, 1839, Botanical Correspondence, vol. 3, SPFC; Samuel B. Buckley to C.W. Short, October 20, 1840, Botanical Correspondence, vol. 3 , SPFC; Gray, "Notes of a Botanical Excursion to the Mountains of North Carolina," pp. $1 \mathrm{ff}$; Gray to C.W. Short, September 7, 1840, Botanical Correspondence, vol. 3, SPFC; Torrey to C.W. Short, September 11, 1840 , Botanical Correspondence, vol. 3, SPFC; Torrey to C.W. Short, April 9, 1841, Botanical Correspondence, vol. 3, SPFC; DAB, 3: 232-233; 4: 614-618.

43 Dupree, Asa Gray, pp. 17, 201; Torrey to C.W. Short, March 21, 1831, Botanical Correspondence, vol. 1 , SPFC.

44 Dupree, Asa Gray, pp. 103-114; C.W. Short to Gray, December $26,1842, \overline{A G H U}$.

45 George Engelmann to C.W. Short, March 15, 1841, Botanical Correspondence, vol. 3, SPEC; DAB, 6: 159-160; Dupree, Asa Gray, p. 97; George H. Daniels, "The Process of Professionalization in American Science: The Emergent Period, 1820-1860," Isis 58 (Summer 1967): 151-166. For information on the professionalization of American science see Sally Gregory Kohlstedt, The Formation of the American Scientific Community: The American Association for the Advancement of Science, 1848-60 (Urbana, Ill.: University of Illinois Press, 1976). 
$46 \mathrm{C}$. W. Short to Engelmann, July 13, 1843, April 5, 1848, George Engelmann Papers, Missouri Botanical Garden Library, St. Louis, Missouri (hereinafter MBGL); DAB, 11: $273-274$.

${ }^{47}$ C.W. Short to W. Short, August 27, 1838, File 21, SPFC; C.W. Short to W. Short, May 10, 1839, File 22, SPFC; C.W. Short to W. Short, January 31, 1843, File 26, SPFC; C.W. Short to W. Short, January 18, 1846, File 29, SPFC.

48 William Darlington to C.W. Short, September 25 , 1839, Botanical Correspondence, vol. 3, SPFC; C.W. Short to W. Short, August 27, 1838, File 21, SPFC; C.W. Short to Engelmann, January 30 , 1842, Engelmann Papers, MBGL.

49 [C.W.] S[hort], "Review of William Darlington's Flora Cestrica," The Transylvania Journal of Medicine and the Associate Sciences 10 (July-September 1837): 499-506.

${ }^{50} \mathrm{C} . \mathrm{W}$. Short, "Observations on the Botany of Illinois," pp. 185-198; C.W. Short to Torrey, March 3, 1838, Rhees Collection, The Huntington Library, San Marino, California; C.W. Short to W. Short, October 16, 1837, File 20, SPEC.

${ }^{51} \mathrm{C}$. W. Short to J.C. Short, February 27,1847 , November 7, 1847, SHSLC; C.W. Short to W. Short, December 8, 1847, File 30, SPFC.

${ }^{52} \mathrm{C}$. W. Short to W. Short, January 30,1848 , File 31 , SPFC; Norwood, Medical Education in the United States Before the Civil War, pp. 297-303; John H. Ellis, Medicine in Kentucky (Lexington, Ky.: The University Press of Kentucky), pp. 16-17.

53 J.C. Short to C.W. Short, october 4,1848 , October 28, 1848, SHSLC; C.W. Short to J.C. Short, October 21, 1848, December 19,1848 , SHSLC.

${ }^{54}$ University of Louisville, Board of Trustees Minutes, June 18,1849, p. 50, ULA; Yande11, History of the University of Louisville, p. 18. 
CHAPTER V

\section{A COUNTRY GENTLEMAN}

In the spring of 1849 , Dr. Short resigned from teaching and the medical profession. During his retirement, he directed the settlement of his Uncle William's estate, managed his financial affairs, maintained Hayfield, cared for and traveled with his family, and pursued his avocation of botany. Although he had anticipated country iffe and retirement to be pleasant and leisured, these years were overshadowed with family illness and death, his failing health, and a general disquietude, probably derived from a lack of activity and mission. From 1849 until his death in 1863, nevertheless, Dr. Short continued to support the study of North American botany. He carried on his extensive correspondence and exchanges of botanical specimens with American and European Botanists, thereby improving his herbarium and knowledge of the science. He also used a portion of his financial inheritance to support scientific exploration through subscriptions and monetary gifts.

With his generous inheritance from Uncle william, Charles had the financial means to purchase his Hayfield estate and retire from the University of Louisville. Uncle William had approved of his resignation, but Charles admitted that in earlier years his uncle surely would have critized his action. Before the end of the year, on December 5, 1849 , 
William Short died at the age of ninety. Charles and Cleves traveled by stagecoach over slippery, snowy mountain roads to Philadelphia, where they arrived too late for William Short's funeral. In devotion to his uncle, Charles agreed to select and compose the inscription for the monument at the Laurel Hill Cemetery gravesite. 1

The brothers stayed in Philadelphia for the reading of their uncle's will. Charles, Cleves, and William's attorney, Samuel Carpenter, were the executors of the estate. William Short made specific bequests to the American Colonization Society, relatives, domestic servants, and his doctor, but the bulk of the estate, which included his Philadelphia house, went to his nephews, Charles and Cleves.? During the next several years, Dr. Short supervised many details of the estate settlement. On May 22, 1850 , Charles, his wife, Mary, and their daughters, Sally, Lucy, and Alice, left the Ohio Valley for Philadelphia, where Dr. Short planned to sell Uncle William's house and attend the court settlement of the estate. The sojourn was also a vacation for the Short family. They left Cincinnati and traveled north by rail to Sandusky, Ohio, on Lake Erie and reached Buffalo, New York, by way of a lake steamer. After visiting Niagara Falls, the family made their way to New York City, where they called on Mrs. Short's relatives, and where Dr. Short complained that most of his vacation had been devoted to keeping the "females and their multitudinous baggage safe." 3

On the last day of May, 1850, the Shorts arrived in 
Philadelphia, where their youngest daughter, eight-year-old, Alice, broke out with measles. The family quickly moved from hot, poorly ventilated hotel rooms to Uncle William's house, where they enjoyed the conveniences of a large dwelling with a water closet. The noise from the omnibusses enroute downtown, however, soon became an annoyance to Dr. Short. While Alice recuperated, the family inventoried Uncle William's belongings and packed articles to be sent to North Bend and Louisville. The library, which numbered approximately 1,600 volumes, and some furniture were included for shipment. While visiting in Philadelphia, Dr. Short took time to call on friends, such as his correspondent, William Darlington, of West Chester, Pennsylvania and John Torrey in Princeton, New Jersey.

The next month, Dr. Short probably accompanied Samuel H. Carpenter, the acting executor of the short estate, before the Philadelphia Register's Court. Carpenter paid inheritance taxes on William Short's property located within Pennsylvania, which valued almost $\$ 90,000$. An 1826 Pennsylvania law provided that inheritances of property within the commonwealth were subject to taxation and in March, 1850, several months after the death of William Short, the state legislature further defined the inheritance law to include the estates of persons who presently lived or had died while residing in Pennsylvania. The attorney argued, however, that the Short brothers, the residual legatees, lived outside the state and, therefore, were not subject to inheritance taxes on personal property located outside the 
state. The court ruled against Carpenter and assessed an inheritance tax on the entire personal estate. The Short brothers and Mr. Carpenter were undoubtedly displeased with the court ruling and considered appealing the decision. 5

Meanwhile, Charles sold his uncle's house and the family finished disposing of the personal belongings. In late July, the family's Philadelphia visit ended abruptly when they received news of the death of their young granddaughter, a child of their daughter Jane Butler. The Shorts left Pennsylvania and traveled to New York City, where they experienced the common frustration of securing hotel accommodations. They finally found rooms at the American Hotel, which the family judged barely tolerable. The situation provoked Charles to comment that "these are the delights of traveling in America--the comfort resorted to by those in search of health and pleasure!!" From New York the family took a direct route to the onio Valley and reached Hayfield by the second week of August. 6

After Dr. Short returned to Kentucky, the executors of William Short's estate sought legal opinions regarding the inheritance tax issue. After securing legal advice from Henry Dilworth Gilpin, a Philadelphia lawyer and former United States attorney general, and Henry Clay, the United States senator from Kentucky, they decided to take the case to the Pennsylvania Supreme Court. In June, 1851, the state appellate court upheld the decision of the lower court. Thomas Ewing, a Cincinnati attorney, urged the Shorts to appeal the decision to the United States Supreme court. On 
January 31, 1855, Ewing and another lawyer, Samuel M. Hart, argued the plaitiff' case before the nation's highest court. Ewing and his associate called the 1850 Pennsylvania Explanatory Act a retroactive, ex post facto law as applies to the estate of William Short, who had died several months before the enactment of the 1850 law. They asked the federal bench to revise the state law. On February 13, 1855, the Supreme Court decided in favor of the defendant and upheld the ruling of the state supreme court. In the court's written opinion, Justice John A. Campbell stated that the 1826 and 1850 laws did not violate the Constitution of the United states, its laws or treaties, and therefore, were not subject to revision by the federal court. The Supreme court, moreover, refused to declare the Pennsylvania inheritance laws ex post facto, reserving its legal application to criminal cases. Pennsylvania received a five per cent inheritance tax on the personal estate of William Short, although he had transferred the bulk of his estate, which included securities and real estate, to his nephews several years before his death.7

During the time of this litigation, Charles and his brother tended to other business relating to their inheritance. The brothers, for example, had acquired Uncle William's property in upstate New York. Charles offered to travel there to inspect the land and afterwards recommend a plan for its dispositon. His son William considered moving there if it proved suitable for farming. Charles' business trip again served as a family vacation. During July, 1852, 
Charles, Mary, and daughters Sally, Lucy, and Alice, retraced a portion of their 1850 trip as they headed for New York. From Cincinnati, they traveled by rail to Cleveland and arrived in Buffalo, New York, via Lake Erie. At Niagara Falls, their son William joined the family entourage, which then crossed Lake Ontario to Ogendensburg, New York, on the St. Lawrence River. Here Dr. Short and his son William surveyed the inherited land. Disappointed with the real estate, William decided not to leave Hayfield and move to New York, and Charles proposed to his brother that they sell the property. 8

During August and September, 1852, the family vacationed in Canada, New England, and the Middle States. After three days in Montreal, Dr. Short registered an unfavorable impression of the city, which suffered from the "blighting influence of papal priestcraft, military dominion, and Frence lethergy." The family visited Boston and proceeded to Long Branch, New Jersey, on the Atlantic Coast, where they stayed two weeks for swimming and other recreation. Although his wife and daughters enthusiastically joined the sea bathers splashing in the ocean, Charles expressed his dislike of the amusement. He observed that both men and women dressed in the "flimsiest manner" and allowed themselves to be "tossed pell mell together" by the ocean waves. He found the sport offensive to his "old-fashioned notions of propriety." For the remainder of their vacation, the family stayed in New York and New Jersey, while Dr. Short took a brief trip to Philadelphia to consult 
with Mr. Carpenter and visit Dr. Darlington in West Chester. Returning to New York to rejoin his family, Dr. Short passed through Princeton, New Jersey, to see another correspondent, John Torrey, who was not at home. While in the East, Dr. Short went to Cambridge to visit another correspondent, the Harvard botanist Asa Gray, who was not at home. Short left a daguerreotype of himself for his friend. Upon his return home, Dr. Gray promptly wrote and invited the short family to be his guests at his home because there was "no one of my correspondents and friends whom I have not seen in the flesh that I am so desirous of seeing face to face." In late September, the Shorts took passage on the Pennsylvania Central Railroad to Pittsburgh en route home. By the last day of the month, they were at Hayfield.9

Charles' son William probably returned to Kentucky after viewing the family's inherited land in upstate New York. Since 1847, he had managed the Hayfield estate, where he had operated a dairy and market garden. The estate was expensive to maintain, however. The farm operations were not profitable and the upkeep of the house and grounds was costly and time-consuming. In 1851, Dr. Short estimated that he had invested almost $\$ 50,000$ on estate improvements and operations. He lamented that Hayfield and retirement did not conform to his idyllic image of country life. Poor health occasionally plagued him and activities, such as church-going at Louisville's First Presbyterian, reading, visits to his children and brother, and botanical and horticultural work at Hayfield failed to relieve the doctor's frequent anxieties. 
He analyzed his disposition as a "discontented and a fretful one" which made him susceptible to "unhappiness and melancholy." Late in the spring of 1851, Dr. Short put Hayfield up for sale, but if offers were received, he did not accept them. Many local residents recognized Hayfield one of the most attractive homes in the area. One summer, for example, Short commented that at least six visitors a day came to his.home, where they took "pleasure in looking at the grass and trees and flowers." Dr. Short found the callers annoying however, and thought they too could enjoy attractive, well-maintained homes, if they worked at it.10

William and his father also were displeased with what they considered to be the unsatisfactory work of their slaves and hired help. Since the 1830s, Louisville had been the residence of a fairly large German immigrant population, which increased during the next twenty years, largely as a result of the unsuccessful European political revolutions of 1848. Irish immigrants, seeking refuge from economic depression and famine in their homeland, also settled in the Ohio Valley. In 1850, Louisville's population included approximately 43,000 inhabitants with about 7,500 German and 3,000 Irish immigrants. Nativist reactions, such as the formation of the Know-Nothing Party with its determination to prevent Roman Catholics and foreigners from holding elected public offices, stirred among some Americans. In 1852, Dr. Short admitted that though he had experienced limited contact with these immigrants, his impression was that they took advantage of the democratic privileges of liberty and 
equality, and became "very insolent and over-bearing fellows." Dr. Short hired several foreign-born gardeners at Hayfield, which probably accounted for his principal encounters and attitudes toward immigrants. Short considered the Irish gardeners "ignorant, conceited, lying, and drunkards," whereas the Germans were "stupid, headstrong, unmannered dirty tobacco smokers." He sought the employment of a Scotsman after he found the English deficient in humility. In late May, 1855 , a provoked Dr. Short reported the handiwork of his German gardner, who had grown "tough stringy radishes, hard black lettuce, and a few stick of asparagus as large as knitting needles." Short wished to hire an American who would be familiar with Kentucky soil and climate, but in 1856, he settled on a Hungarian horticulturist. 11

Although Dr. Short was concerned for the well-being of his slaves, he often expressed his dissatisfaction with their work. He frequently considered slavery an annoyance. One Christmas, for example, he commented that during the holiday season, his slaves were like the rebellious "Roman servants in the time of Horace during their Saturnalia." According to the 1850 United States census, Dr. Short owned six male slaves, ranging in age from fourteen to fifty, and five female slaves, ages eighteen to fifty. In 1840, when he had lived in the city, he had owned six slaves. Dr. Short opposed immediate emancipation because of his belief that slaves lacked skills and education to compete in the job market and thereby achieve self-sufficiency. He supported, 
at least for a time, the efforts of the American Colonization Society. In 1846 , he recorded the donation of $\$ 200$ in a five-year period to the society, money which was used, in part, for the establishment of a Kentucky colony in Liberia. By 1849, however, Charles considered the manumission project "a bad scheme" and cited his disgust with the Liberians" internal management of their new country. In that year, Charles Gist, a Liberian immigrant whom William Short had secured from the estate of his brother Peyton and later sponsored in the African colony, was executed for the murder of his wife's lover. Dr. Short saw the Gist incident as a symbol of the futility of the emancipation plan.12

Hayfield's operational expenses prompted Dr. Short to encourage his son to relocate on another farm. In 1858, William sold his ninety-five acre share of Hayfield for $\$ 20,000$ and purchased Hazel Hill, which was located four miles south of Elizabethtown, in Hardin County, Kentucky. Life at Hayfield doubtlessly changed when William, his wife Matilda, and their three children moved to Hazel Hill; their departure left only three Short family memebers, Dr. Short, his wife Mary, and daughter Alice, at Hayfield. The elder Shorts occasionaly visited their son and his family by way of a forty-six mile train ride on the Louisville and Nashville Railroad. On his visits to Hazel Hill, Dr. Short enjoyed conducting botanical research of another area of the commonwealth, where he collected and preserved plant specimens, especially of the aster and solidago (goldenrod) varieties. 13 
The train also made possible a three hour and twenty minute trip to the home of the Shorts' daughter Jane Butler and her family in Franklin County, Kentucky. Early in 1857, the Butlers had moved from their Texas stock farm, which Dr. Short had helped finance, to the Forest Hill estate, also purchased by Short for his daughter and family. At Forest Hill, located on the Georgetown turnpike about six miles outside Frankfort, Dr. J. Russel Butler raised cattle and horses. Since Dr. Short preferred the central Kentucky environment to the climate of the Ohio Valley, the Shorts paid frequent visits to the Butler's home. 14

Dr. Short's inheritance paid sizable dividends, a fact which allowed him to purchase houses for his married children and also to invest in land speculation. Besides his contributions to William and Jane, he had bought a house for his eldest daughter Mary, who had married William Allen Richardson in 1841; his daughter Sally, who, in 1853, had married Dr. Tobias Gibson Richardson, the younger brother of Mary's husband; and Lucy, who had married Joseph B. Kinkead in 1855. In 1862, Dr. Short recorded the assessment of land taxes on his five plots in McLean County, Illinois, in addition to 1,260 acres in Lucas County, Iowa, and 720 acres in Hancock County, Iowa. 15

Dr. Short's retirement and inheritance also furnished time and money for the family to travel and enjoy diversions from their home and Louisville. Besides their 1851 and 1852 trips, the Shorts returned to the East during the summers of 1856 and 1858. The last trip ended abruptly when Dr. Short 
became ill in Philadelphia after exploring the Pine Barrens of New Jersey, and the family returned to Kentucky. The 1856 journey, however, began in mid-July and extended throughout the summer months. The family returned to Long Beach, New Jersey, where according to Dr. Short, his wife could take advantage of the "sanative and youth-restoring influences of sea-bathing." Their itinerary also included visiting relatives in New Jersey and New York, while Dr. Short took a trip to Philadelphia to meet with his business agent, Samuel H. Carpenter. 16

In Philadelphia, Short called on Elias Durand, one of his correspondents. For two years, Durand had worked at the Academy of Natural Sciences, where he was arranging the North American herbarium. His personal collection contained Constantine Samuel Rafinesque's herbarium, which Durand had purchased after the death of the former Transylvania professor. From the Rafinesque collection, Durand had become familiar with Short's skill at plant preservation and subsequently requested and received specimens from Short for the academy's herbarium. Dr. Short was interested in Durand's assessment of the Rafinesque collection because Rafinesque had boasted about his extensive collections and had offered Short unsolicited advice on preservation techniques. Durand rated Rafinesque's collection as "trash, incomplete, and good for nothing," although the specimens had been stored and neglected for some time before Durand's possession. Durand's comments, nevertheless, confirmed Dr. Short's opinion of the eccentric naturalist, who short 
considered a "bare-faced liar."17

Earlier in 1856, Dr. Short had sought Asa Gray's advice concerning the disposition of his herbarium, which Short claimed contained specimens of all known American plants and an extensive European collection. Short insisted that it be adequately stored and available for research. Since no western or southern institution was equipped to accommodate. the herbarium, Dr. Short turned to the East, the center of the nation's scientific activity, for his bequest. His 1856 visit to Elias Durand included a tour of the Academy of Natural Sciences' botanical collections. Dr. Short found the academy's herbarium neglected and lacking in supplies, equipment, space, and management. He decided not to donate his extensive collection to the academy and asked Dr. Gray to contact officials at the Smithsonian Institution about their interest in his herbarium. Dr. Short later reconsidered this plan, when the Smithsonian placed what Short considered to be too many restrictions on his prospective donation. 18

Botany remained Dr. Short's chief interest and occupation. During the winter months at Hayfield, he studied current botanical literature and worked on his herbarium. He had constructed about three hundred cases, which resembled large books, for the storage of his botanical collection. Each box displayed a number and a label and measured approximately twenty inches high, by twelve inches deep, and almost three inches wide. In addition to his American correspondents, Dr. Short's correspondence and plant exchanges with foreign botanists included Professor William 
Henry Harvey, Trinity College, Dublin, Ireland; Dr. Joachim Steetz, Hamburg, Germany; Heinrich Gustav Reichenbach, Dresden, Germany; Charles Francois Brisseau de Mirbel, Paris, France; Richard Chandler Alexander, Hammersmith, England; and Professor Charles Daubeny, Oxford University.' Short traded copies of personal portraits as well as plant specimens with the Genevan botanist Alphonse De Candolle and Sir William Jackson Hooker, director of the Royal Botanic Gardens at Kew. 19

Short received recognition from his fellow sceintists for his contribution to the study of botany. From 1849 to 1851 his name appeared on the membership directory of the American Assocation for the Advancement of Science. In 1855, upon the nomination of Asa Gray, the American Academy of Arts and Sciences elected Dr. Short to membership, and in 1851 , the organizers of the newly-established Louisville Natural History Society selected him to be their first president. The society met at the University of Louisville, sponsored lectures, and collected Kentucky flora and fauna. Dr. Short probably was not very active in the organization, which prospered only a few years before its collection burned in a fire. Dr. Short's reputation, therefore, was acknowledged by community naturalists as well as scientists across the country. 20

\section{After 1849 Short's primary contribution to the} advancement of botany was through financial patronage. Specificaliy, he made monetary donations to explorers and frequently subscribed to their plant collections. From his 
experiences in Kentucky, Dr. Short believed that the western exploring parties, in particular, should include trained botanists "to make proper selections and collections in a new and unknown country." The vast territory invited more plant explorers than the government expeditions provided. A few trailblazing botanists, therefore, sought financial support for their work in the new lands. 21

Word of Dr. Short's inheritance circulated among his scientific correspondents. In 1850 , Torrey advised Samuel Botsford Buckley, a botanist: known for his expeditions in the American South, to seek money from Short, who offered to lend Buckley monetary aid for his proposed trip to the Great Salt Lake region. Evidently Buckley did not collect the gift. That year Dr. Short also contributed $\$ 100$ toward Charles Wright's botanical explorations of Texas and in 1851, Dr. Short paid $\$ 36.50$ for dried plants from Ferdinand Jacob Lindheimer. In 1856 and 1858, Dr. Short subscribed to August Fendler's collection of Venezuelan plants. This Prussian-born botanist had traveled across parts of the central and western United states in addition to Central America on botanical explorations before embarking on his South American wanderings. Short later offered to give $\$ 500$ a year to explore California, Florida, and Mexico; no evidence exists, however, that Fendler accepted the offer.22 Through Asa Gray, Dr. Short purchased Jean Louis Berlandier's herbarium of Texas and Mexican plants. Short's correspondent, the Genevan botanist, Augustin-Pyramus De Candolle, who was noted for his pioneer work in the 
development of the natural method of plant taxonomy, had sponsored his student Berlandier's immigration and exploration of Mexico. The Frenchman arrived in the United States around 1826 and eventually settled in Mexico, where he operated an apothecary. He died in 1851 leaving a herbarium which surviving botanists expected to hold a rich harvest. Dr. Short paid $\$ 400$ for the collection and asked Dr. Gray to distribute the specimens among several botanists and the Smithsonian Institution. Unknown to Gray, the Berlandier collection was inadequately preserved and a disappointment to both Gray and Short, who asked that his name not be associated with what the Harvard botanist considered a "meagre and superlatively wretched" collection. 23

John Torrey, who was aware of Short's wealth and sincere interest in botany, suggested another project for his patronage. In 1851, he recommended that Dr. Short sponsor an expedition to North Carolina to locate Shortia galacifolia, which had been christened by Dr. Gray in 1839 and still remained undiscovered in its natural habitat. Short had planned to make the expedition himself, but because of personal and family sickness he had always cancelled his trips. Moses A. Curtis, his correspondent from South Carolina, was confident of Shortia's rediscovery and speculated that it bloomed in the early spring rather than during the autumn season. In September, 1851, Dr. Short again planned a spring trip to the Carolina mountains. 24 The following January, Asa Gray, who had already explored within the Appalachian Mountains, encouraged Short 
to investigate the valley behind Table Mountain, North Carolina, and then proceed to Black Mountain, following André Michaux's route. Apprehensive about the rediscovery, Dr. Short feared that the plant which Michaux had labelled "hautes montagnes" (high mountains) and which Gray named Shortia galacifolia was actually a plant Michaux had discovered in Labrador or Persia. Dr. Torrey reminded Short that the label, which read "hautes montagnes de Caroline," included a more specific reference of the plant's habitat and he made a sanguine prediction of its rediscovery. 25

Dr. Short never followed Gray's requests that he undertake a botanical expedition to the Carolinas, but along with Torrey and Gray he no doubt felt obliged to aid in the rediscovery of the plant. In 1852, Short proposed to sponsor J.H. Lundgren, a Swedish botanist befriended by Torrey, on a botanical trip to the Carolina mountains. On April 19, 1852, Lundgren agreed to explore for two to five months, at which time he could be recalled by Dr. Short. Whenever possible, Lundgren would collect ten specimens of every noteworthy plant, one set of which he could keep, while the other nine would be forwarded to Short. Dr. Torrey would administer the contract and Short agreed to pay all expenses. 26

The Lundgren quest ended in mystery. During the latter part of April, 1852, he left New York City fully equipped to search for Shortia and to collect other botanical specimens. By May, Lundgren had reached Charleston, South Carolina, and the home of Professor Lewis Reeve Gibbs, an expert on the botany of the Charleston area and a long-time 
correspondent of Short's. From there Lundgren planned to go to Asheville, North Carolina, and then west to Cherokee County. During the spring months, Torrey communicated with Swede. By September, Torrey and Short were assuming that he had finished his explorations. By October, however, neither man had received word from Lundgren and they feared for his safety. At that time, Dr. Short received a letter for I.F.E. Hardy, an Asheville physician who had loaned Lundgren eighty dollars. Dr. Hardy reported that the explorer had left Asheville for Cherokee County, but had not returned.27

For two months Short and Torrey corresponded with Dr. Hardy regarding the Lundgren disappearance. Dr. Lundsford P. Yandell, Sr., professor in the Medical Department of the University of Louisville and former collegue of Dr. Short, traced Luundgren through Dr. Frank A. Ramsey of Knoxville, Tennessee. Ramsey reported that Lundgren had boarded in Athens, Tennessee, a small town south of Knoxville. Dr. Hardy added that Lundgren had taken railroad passage from Knoxville to Dalton, Georgia, possibly on his way to Cherokee County. By the end of December, 1852, Short and Torrey had concluded that they had been deceived by Lundgren, and called off the search. Short instructed Torrey, as the administrator of the Lundgren account, to settle any outside debts and to arrange for the distribution of the few botanical specimens left with Dr. Hardy by Lundgren. Almost a year later, Short still pondered the disappearance and motivation of Lundgren, "the scamp . . who pretended to be botanizing." 28 
In 1857, five years after the Lundgren affair, John Torrey confided to Asa Gray that perhaps Dr. Short was displeased with him over the unfortunate mishaps of the Swede. On the contrary, Dr. Short reaffirmed his friendship with Dr. Torrey and presented the Princeton professor with a complimentary collection of algae he had received from Irish correspondent William Henry Harvey, an expert on North American maṛine algae.29

Short continued his friendship with Drs. Torrey and Gray. He admired their work; and respected their honored positions among the country's botanists. In the 1850s, Asa Gray took charge of forwarding Short's parcels of seeds, plants, and other botanical specimens to foreign correspondents, including Sir William Hooker. He also continued to counsel short about the disposition of his herbarium, in addition to securing paper on which Dr. Short affixed his dried plant collection. In 1860, Dr. Short presented the Harvard professor with botanical books from his library, including the first thirty-two volumes of Curtis's Botanical Magazine, which had been edited by their friend Hooker. As part of the gift, Short instructed Dr. Gray to purchase the remaining volumes to complete the set. 30 On the eve of the Civil War, Short and Gray exchanged personal reactions to the nation's political strife. Asa Gray was a Republication and in 1860 he supported the party's nominee, Abraham Lincoln; Short cast his vote for the nominee of the Constitutional Union Party, John Bell. Although Dr. Short, in his earlier days, rarely commented about 
political matters in writing, he identified himself as a Whig. He had embraced the philosophies of Kentucky's native son Henry Clay: a protective tariff, a Bank of the United States, and internal improvements. 31

The deaths of Clay and Daniel Webster was followed by the demise of national Whig solidarity and led to the hardening of party politics along sectional lines. Short, who defended slavery and opposed abolitionism, viewed the crisis as a failure in self-government. The Constitutional Union party, a coalition of Southern Whigs, moderate Democrats, and American Party members, vowed to preserve the Union, though the party platform made no reference to the slavery issue. In February, 1861, after the election of Lincoln and in the midst of the creation of the Confederate States of America, Dr. Short admitted to Gray that perhaps a dissolution of the Union was the best solution to the crisis because of the "dissemilitude and repulsion" between the two sections. Short, whose financial investments included considerable northern holdings, supported Kentucky's affirmative stance in the Union. In November, 1861, seven months after Ft. Sumter fell to the Confederates, Dr. Short confided to Gray that while he believed in state rights, he favored forceful actions by the federal government to save the Union. 32

Amid the philosophical threat of "Northern fanatics" and "Southern fire-eaters," Dr. Short counted himself among the majority of Louisvillians who identified with the Union. Two of his sons-in-law, Drs. J. Russell Butler and Tobias 
Gibson Richardson, on the other hand, sympathized with the South and joined the confederate army. At the beginning of the conflict, the Commonwealth of Kentucky declared neutrality. When Confederate and Union troops invaded Kentucky, the legislature resolved on September 13,1861 , to demand the withdrawal of the southern army and thereby voiced Kentucky's support of the Union. Northern troops billeted in Louisville, which became a garrison for soldiers and material. In the summer and autumn of 1862 , the Confederates launched a major offensive in the East and West. By August, General Edmund Kirby Smith and General Braxton Bragg each were leading southern armies into Kentucky, headed toward Louisville. Union General William "Bull" Nelson and his troops prepared to defend the city, while northern soldiers led by General Don Carlos Buell proceeded to head off Bragg's army before he reached his destination at the falls of the Ohio River. 33

Many Louisvillians and neighbors fled the city on the eve of the impending Battle of Louisville. Dr. Short reported the rumor that General Nelson planned to burn down the river town rather than surrender to the confederates. On September 24, 1862, Dr. Short, his wife Mary, daughters Alice Short and Lucy Kinkead, with Lucy's four children, and nine trunks arrived in Cincinnati, where they stayed in a hotel for several weeks. The slaves probably remained at Hayfield. Bragg's army, however, did not reach Louisville. On October 8,1862 , the opposing armies met at the Battle of Perryville in central Kentucky.34 
Rather than return to Hayfield where they might face the threat of wandering troops, the shorts rented a furnished house in Louisville at the corner of Third and Broadway for the remainder of the winter of 1862-1863. Shortly after the family settled in the city, probably in mid-January, Dr. Short became ill. On February 24, 1863, William observed that his father had shown no improvement. Two days later Dr. Short penned his final will and testament. In Louisville on the first day of March, John Cleves Short reported that his brother was "very low indeed . . but I fear will never recover." Cleves, who had brought his younger brother brandy and whiskey for medicinal purposes, returned to his home, Shorthill, on March 6. The next day, on Saturday afternoon, Dr. Short experienced a chill and died of typhoid pneumonia about six o'clock that evening. He was sixty-eight years old. His daughter Mary Short Richardson remembered that her father died with a "smile on his countenance," although during his six-week illness he had not smiled and had not expected to recover. 35

On Monday, March 9, 1863, John Cleves Short learned of his brother's death. Funeral services were held that day at three o'clock at the family's city residence. Charles Wilkins Short was buried in a metal coffin and placed in a receiving vault in Cave Hill Cemetery, where he was later interred. His daughter Jane short Butler wrote the following inscription for her father's monument:

During a long period of his life, he devoted the riches of a well stored mind, to instruction in medical science, principally directed toward that 
branch, which was his favourite and well beloved study, Botany.

In the relations of domestic life, none ever lived more faultless. To the limited circle, of those favoured by his friendship, he was ever true and faithful. To his God, he has rendered a good account of the talents committed to his keeping.

His end was perfect Peace. 36

Dr. Short spent his retirement years caring for his large family, in which sickness was commonplace, and managing his business affairs as well as Hayfield. The family recognized his devotion to them and his affection for the study of botany. Despite his serious attitude toward family responsibilities, poor health, and the political state of the country, Dr. Short continued his correspondence and exchanges with botanical colleagues. His pioneer work in the identification and classification of the flora of Kentucky was a contributing factor in the advancement of American botany. Later his financial patronage enhanced the advancement of botanical exploration. Life as a country doctor, a medical professor, and finally a country gentleman, carried no pleasures or rewards for him comparable to botanical study and research. 
1DAB, 17: 128-129; Charles Wilkins Short to John Cleves Short, September 14, 1849, March 22, 1850, Short, Harrison, and Symmes Family Papers, Library of Congress, Washington, D.C., microfilm in the Filson Club (hereinafter SHSLC); J.C. Short to Mary Short, December 15, 1849, Short Family Papers, Cincinnati Historical Society, Cincinnati, Ohio (hereinafter SPCHS); Mary C. Short to [Mary Short Richardson], June 26, 1850, Charles Wilkins Short Papers, Southern Historical Collection, University of North Carolina, Chapel Hill; North Carolina (hereinafter SPSHC).

2 George Green Shackelford, "William Short, Jefferson's Adopted Son, 1758-1849" (Ph.D. dissertation, University of Virginia, 1955), pp. i-x, 518-533; J.C. Short to C.W. Short, February 5, 1850, February 14, 1850, August 20,1850 , SHSLC.

${ }^{3}$ C.W. Short to J.C. Short, May 13, 1850, SHSLC; C.W. Short to J.C. Short, May 30, 1850, SPSHC.

${ }^{4}$ C.W. Short to J.C. Short, June 14, 1850, July 4, 1850 , June 11,1850 , SPSHC; J.C. Short to C.W. Short, June 19, 1850, August 10, 1850, SHSLC; C.W. Short to J.C. Short, August 9, 1850, Charles Wilkins Short Papers, American Philosophical Society Library, Philadelphia, Pennsylvania (hereinafter SPAPS); C.W. Short to George Engelmann, September 23, 1850, George Engelmann Papers, Missouri Botanical Garden Library, St. Louis, Missouri (hereinafter MBGL); John Torrey to C.W. Short, August 24, 1850, SPSHC; DAB, 5: .78-79.

5 J.C. Short to C.W. Short, June 7, 1851, SHSLC; Carpenter et al. v. Commonwealth of Pennsylvania, 15 Law. Ed. $127(1854)$. 1850, SPSHC.

${ }^{6}$ C.W. Short to J.C. Short, July 22, 1850, July 25,

${ }^{7}$ C.W. Short to J.C. Short, May 11, 13, 1851, SPSHC; J.C. Short to C.W. Short, June 7, 1851, November 12, 1851 , SHSLC; DAB, 3: 456-459; 4: 173-179;6: 238-239; 7 : 315-316; Carpenter et al. v. Commonwealth of Pennsylvania, 15 Law. Ed. $127(1854)$.

${ }^{8}$ C.W. Short to J.C. Short, July 21, 1852, July 26 , 1852, August 5, 1852, sPSHC.

${ }^{9} \mathrm{C}$. W. Short to J.C. Short, August 21, 22, 1852 , August 28,1852 , September 10, 1852, September 17, 1852 
September 30, 1852, SPSHC; C.W. Short to Asa Gray, September 5, 1852, Asa Gray Papers, Gray Herbarium Library, Harvard University, Cambridge Massachusetts (hereinafter AGHU); Torrey to C.W. Short, November 30, 1852, SPSHC; Gray to C.W. Short, September 8, 1852, SPSHC.

${ }^{10} \mathrm{C}$. W. Short to J.C. Short, May $11,13,1851$, May 26, 1851, September 15, 1851, SPSHC; C.W. Short to J.C. Short, March 19, 1852, April 27, 1856, SPAPS; C.W. Short to J.C. Short, January 21, 1855, Reid Collection, Charles Wilkins Short Papers, Filson Club, Louisville, Kentucky (hereinafter SPFC); C.W. Short to J.C. Short, June 7, 1855, File 61, SPFC; C.W. Short to J.C. Short, February 23, 1858, SHSLC.

${ }^{11}$ C.W. Short to John Torrey, October 15, 1852, John Torrey Papers, New York Botanical Garden Library, Bronx, New York (hereinafter NYBG); George H. Yater, Two Hundred Years at the Falls of the Ohio: A History of Louisville and Jefferson County (Louisville, Ky.: The Heritage Corporation, 1979), pp. 60-71; C.W. Short to J.C. Short, September 15, 1851, September 10, 1853, SPSHC; C.W. Short to J.C. Short, May 30, 1853, File 61, SPFC; C.W. Short to J.C. Short, November 23, 1856, Thomas A. Courtenay Collection, Simpsonville, Kentucky (hereinafter Courtenay Collection). For information on nativist reactions in Kentucky before the Civil War see Agnes Geraldine McGann, Nativism in Kentucky (Washington, D.C.: The Catholic University of America, 1944).

${ }^{12} \mathrm{C}$. W. Short to J.C. Short, January 2, 1854, File 61 , SPFC; C.W. Short to J.C. Short, May 26, 1851, SPSHC; U.S., Department of Commerce, Bureau of the Census, Seventh Census of the United States, 1850: Slave Population, Jefferson County, Kentucky, p. 986; U.S., Department of Commerce, Bureau of the Census, Sixth Census of the United States, 1840: Jefferson County, Kentucky, p. 133; W. Short to C.W. Short, October 28, 1837, File 7, SPFC; C.W. Short to W. Short, November 17, 1839, File 22, SPFC; Alexander M. Cowan to C.W. Short, September 29,1845 , File 70 , SPFC; C.W. Shosrt to J.C. Short, August.18, 1849, SHSLC.

$13 \mathrm{C}$. W. Short to J.C. Short, December 21,1858 , SHSLC; C.W. Short, Daily Journal, April 4, April 9, September 24 , 1860, File 167, SPFC.

${ }^{14} \mathrm{C}$. W. Short to J.C. Short, May 30, 1853, File 61, SPFC; C.W. Short to J.C. Short, December 10, 1854 , SPSHC; C.W. Short, Diary, January 10, March 30, August 18, 1857, Courtenay Collection; Charles Wilkins Short, Will, Will Book 6 , p. 70 , Jefferson County, Office of the County Clerk, Louisville, Kentucky; C.W. Short to J.C. Short, May 2, 1858, December 13, 1858, SHSLC; C.W. Short Daily Journal, August 22, 1860, File 167, SPFC.

15 Charles Wilkins Short, Will, will Book 6, p. 70 , 
Jefferson County, office of the County Clerk, Louisville, Kentucky; Tobias Richardson to C.W. Short, January 12, 1854 , File 72, SPFC; DAB, 15: 575-576; Iowa Land Papers, Tax Receipts, File 123 , SPFC; Illinois Land Papers, Tax Receipts, 1856-1862, File 121, SPFC; C.W. Short and Mary Churchill Richardson, "A Chronological Record of the Families of Charles Wilkins Short and May Henry Churchill," 1843, 1879, p. 11, SPFC.

${ }^{16}$ C.W. Short to J.C. Short, July 30, 1856, SPAPS; C.W. Short to Gray, october 3, 1856, October 13, 1858, AGHU.

17 DAB , 5: 538-540; 15: 322-324; Elias Durand to C.W. Short, March 25, 1836, SPSHC; Durand to C.W. Short, June 11, 1856, SPAPS; C.W. Short to Gray, October 3, 1856, AGHU .

$18 \mathrm{DSB}, 5: 511-514 ;$ C.W. Short to Gray, March 15 , 1856, October' 3,1856 , November 16, 1856, December 28, 1859 , AGHU; C.W. Short to J.C. Short, May 8, 1858, SHSLC; C.W. Short to J.C. Short, May 8, 1858, SHSLC; C.W. Short to J.C. Short, April 17, 1862, SPAPS.

${ }^{19} \mathrm{C}$. W. Short to Gray, March 13,1850 , June 10,1854 , December 21, 1854, January 13, 1856, AGHU; William Short to Durand, November 20, 1863, Charles Wilkins Short Papers, Academy of Natural Sciences of Philadelphia Library, Philadelphia, Pennsylvania (hereinafter ANSP); C.W. Short to Torrey, July 24, 1851, October 31, 1859, Torrey Papers, NYBG; C.W. Short to J.C. Short, September 3, 1855, SPFC; Gray to C.W. Short, October 13, 1855 , October 26, 1855, SPSHC; DSB, 3: $42-43,585-586 ; 6: 162-163,492-495 ; 9: 418-419$.

${ }^{20} \mathrm{C}$. W. Short to Gray, December 25,1855 , AGHU; B[enjamin] Silliman, Jr. to C.W. Short, December 5, 1851 , December 8, 1851, SPSHC; Sally Gregory Kohlstedt, The Formation of the American Scientific Community: The American Association for the Advancement of Science, 1848-60 (Urbana, Ill.: University Press of Illinois, 1976), appendix; Walter B. Hendrickson, "Museums and Natural History Societies in Louisville," Filson Club History Quarterly 36 (January 1962): 47-53.

21 Dupree, Science in the Federal Government (Cambridge, Massachusetts: The Belknap Press of Harvard University Press, 1957), pp. 91-95; C.W. Short to Torrey, February 27, 1852, September 26, 1853, Torrey Papers, NYBG.

22DAB, 3: 232-233, 11: 272-274, 20: 545-546; $\mathrm{S}$ [amuel] B[otsford] Buckley to C.W. Short, September 2, 1850 , SPSHC; C.W. Short to Torrey, July 24, 1851, Torrey Papers, NYBG; Charles Wright to C.W. Short, November 29, 1851, SPSHC; Torrey to C.W. Short, September 21, 1850, August 7, 1851, SPSHC; C.W. Short to Engelmann, January 7, 1850 , Engelmann Papers, MBGL; C.W. Short to Gray, March 26, 1856, October 26, 
1858, May 30, 1859, AGHU; William M. Canby, ed. "An Autobiography and Some Reminiscenses of the Late August Fendler," Botanical Gazette 10 (June-August 1885): 285-290.

23 Susan Delano McKelvey, Botanical Exploration of the Trans-Mississippi West, 1790-1850 TJamaica Plain, Massachusetts: The Arnold Arboretum of Harvard University, 1955), pp. 365-381; DSB, 3: 43-45; C.W. Short to Gray, November 10, 1853, July 21, 1854, August 5, 1854, AGHU; Gray to C.W. Short, July 6, 1854 , SPSHC; Gray to C.W. Short, December 26, 1854, Short Papers, ANSP.

24 [Torrey] to C.W. Short, August 7, 1851, SPSHC; C.W. Short to J.C. Short, September 28, 1851, October 16, 18, 1851, SPAPS; Moses A. Curtis to C.W. Short, September 9, 1851, SPSHC:

25 Gray to C.W. Short, January 17,1852 , SPSHC; C.W. Short to Torrey, January 31, 1852, Torrey Papers, NYBG; Torrey to C.W. Short, February 14, 1852, Short Papers, ANSP; Gray, "Notes of a Botanical Excursion to the Mountains of North Carolina," The American Journal of Science and Arts, 1st ser. 42 (October-December 1841): 48 .

${ }^{26}$ C.W. Short to Torrey, March 22, 1852, May 6, 1852, Torrey Papers, NYBG; Torrey to C.W. Short, April 19, 1852, SPSHC; J.H. Lundgren Agreement, April 19, 1852, SPAPS.

27 Torrey to C.W. Short, May 1, 1852, May 18, 1852, June 22, 1852, SPSHC; Lundgren to C.W. Short, May 8, 1852, SPSHC; C.W. Short to Torrey, October 15, 1852, Torrey Papers, NYBG; I.F.E. Hardy to C.W. Short, October 20, 1852, File 71 , SPFC.

${ }^{28}$ C.W. Short to Torrey, Octoer 30, 1852, November 21, 1852, December 6, 1852, December 31, 1852, February 26, 1853, September 26, 1853, Torrey Papers, NYBG; Torrey to C.W.' Short, November 5, 1852, December 23, 1852, SPSHC; Hardy to C.W. Short, November 10, 1852, December 14, 1852, File 71, SPFC; Frank A. Ramsey to L.P. Yandell, December 1, 1852, File 71 , SPFC. 1857, AGHU.

${ }^{29}$ C.W. Short to Gray, May 19, 1857, September 10,

30 Gray to C.W. Short, December 26, 1854, Short Papers, ANSP; Gray to C.W. Short, February 5, 1855, October 10,1856 , SPSHC; C.W. Short to Gray, January 18, 1860 , January 25, 1860, January 29, 1860, AGHU.

31 Dupree, Asa Gray, pp. 307-309; C.W. Short, Daily Journal, November 6, 1860, File 167, SPFC; DAB, 2: 157-159; 4: 173-179; 11: 242-259; C.W. Short to J. $\bar{C}$. Short, November 11,1844 , SHSLC; C.W. Short to W. Short, November 27, 1844 , File 27 , SPFC. 
32David M. Potter, The Impending Crisis, 1848-1861 (New York: Harper \& Row, 1976), pp. 415-418; DAB, 19: 585-592; C.W. Short to Gray, December 17, 1860, February 18, 1861, July 16, 1861, November 14, 1861, AGHU; C.W. Short and Richardson, "A Chronological Record of the Families of Charles Wilkins Short and Mary Henry Churchill," pp. 183-186, SPFC.

33 C.W. Short to Gray, May 26, 1861, AGHU; Yater, Two Hundred Years, pp. 82-91; C.W. Short and Richardson, "A Chronological Record of the Families of Charles Wilkins Short and Mary Henry Churchill," p. 186, SPFC; DAB, 2: $385-387 ; 3: 240-241 ; 10: 424-426$.

34 Yater, Two Hundred Years, pp. 82-91; C.W. Short to J.C. Short, September 24, 1862, SPAPS; C.W. Short to Gray, December 1, 1862, AGHU.

${ }^{35} \mathrm{C} . \mathrm{W}$. Short to Gray;, December 1, 1862, AGHU; W. Short to J.C. Short, February 24, 1863, SPCHS; C.W. Short, Will, Will Book 6, p. 70, Jefferson County, Office of the County Clerk, Louisville, Kentucky; J.C. Short to Mary Short, March 1, 1863, March 12, 1863, SPCHS; Louisville Daily Journal, March 9, 1863, p. 3; Mary Richardson to J.C. Short, March 10, 1863 , SPCHS.

36 J.C. Short to M. Short, March 12, 1863, SPCHS;

M. Richardson to J.C. Short, March 10, 1863 SPCHS; Louisville Daily Journal, March 9, 1863, p. 3; Jane Short Butler, "A Tribute to the Memory of Charles Wilkins Short," File 72, SPFC. 


\section{CHAPTER VI}

\section{THE LEGACY}

Dr. Short died in 1863; his legacy, however, survives. His immediate family and descendants sought to perpetuate his memory not only through oral tradition but through the disposition of his personal papers and library for scholarly use. The Hayfield estate remains a private home and a symbol of Short's gentility and wealth, whereas the site of his summer home, Fernbank, Ohio, is now a neighborhood within the corporate limits of Cincinnati. Colleagues memoralized the pioneer Kentucky botanist and medical professor and his scientific succssors have continued his work.

Literary reminiscences written by Short's friends are lasting tributes to his memory. Asa Gray, for example, eulogized his long-time correspondent in The American Journal of Science and Arts, where he praised Short for his extensive plant collections, preservation techniques, and unselfish exchanges. In Gray's opinion, Dr. Short exhibited traits that American botanists should strive to emulate. Dr. Gray surmised that his colleague's "retiring and unambitious disposition," not a lack of intelligence or scientific knowledge, had probably reduced the number of his scholarly writings and stymied the publication of his Flora of Kentucky. Likewise, Dr. Henry Miller, who had been Short's 
personal physician and had taught with him at the University of Louisville Medical Department, honored his former friend in an obituary notice. He described Dr. Short as a fastidious, modest, and timid man, whose dignified, self-disciplined manner obscured his kind nature. 1

At the request of the American Philosophical Society, Dr. Samuel David Gross wrote what is now a well-known biographical sketch of Short. Professor Gross, who had taught with Dr. Short in Louisville, lived in Philadelphia, where he was on the faculty of the Jefferson Medical College. In 1861, he had published the Lives of Eminent American Physicians and Surgeons of the Nineteenth Century which won him recognition as a medical biographer and historian. Dr. Gross sought information from Mrs. Short on his friend and fellow society member. By 1865 , Gross had completed his manuscript of the biographical essay and forwarded it to the subject's widow for her perusual. In November, 1865, Gross's obituary notice of Dr. Short appeared in the society's Proceedings and at the family's request, 200 reprints of the memoir were sent to Louisville. Today, it is not uncommon to find copies in the possession of Dr. Short's descendants.?

Gross's biographical sketch provides information, which for the most part is accurate, about Dr. Short's private and public life. His personal remembrances, moreover, are especially enlightening. Dr. Gross recalled that his former Kentucky colleague had been of "medium height, weil proportioned, with light hair and complexion, blue eyes, and an ample forehead." An 1830 s portrait of 
Short reveals, in fact, that the subject had red hair. He described Dr. Short's manner as "graceful, calm, and dignified," but "with a mind of inflexible firmness upon all questions of duty." Of the biographers, only Samuel Gross mentions Short's sense of humor as one of his distinctive attributes. 3

Dr. Short's legacy can also be traced through his family. In.his will, short bequeathed to his family a substantial estate. The will, written in his hand several days before his death, specifically stated that each one of his six children was to share equally in the division of the estate, which at the time of the will's probation amounted to at least $\$ 250,000$. Dr. Short included in the document an account of the money and value of property he had already given each child. The total respective amount was to be applied toward each child's share. In addition, Short willed that each married daughter and his only daughter-in-law was to receive $\$ 25,000$ in trust separate from her husband's property, thereby protecting each one and her children from possible debts incurred by the spouse. Likewise, Short's unmarried daughter, Alice, also received a $\$ 25,000$ share in addition to a $\$ 50,000$ trust. Mrs. Short received a $\$ 5,000$ annuity, in addition to the household belongings, which included "silver ware and plate, and the large carriage and a pair of good horses." Dr. Short stipulated in the will's codical that his three male slaves were to be emancipated after the will was probated, and his only female slave was to receive her freedom on January $1,1865.4$ 
Although Dr. Short specifically stated in his will that his library was to be divided among his children, he made no written provision regarding the disposition of his personal papers. One biographer, who studied Short's record of letters sent and received, in addition to other manuscripts, estimated that Dr. Short had written more than 5,000 letters and consequently received a voluminous number in return. Short's correspondence with family members began at an early age; his letter-writing expanded in substance and quantity with his maturity and reputation as a Kentucky botanist. His writings, both published works as well as his correspondence, are marked with an elegant, graceful, and concise style. After Short's death, his personal papers, which included letters from family members, business agents, and scientists; diaries; botanical drawings; and financial records apparently were distributed among his children. 5

Dr. Short's well-preserved, extensive family archives demonstrates his interest and intent in documenting legal, financial, and professional affairs as well as his genealogical history, which was a common pastime of scientists during the nineteenth century. Dr. Short retained only those papers he deemed worthy of retention according to the value of information they contained on subjects such as "business, friendship, sciences, literature, or anything else." His brother had cautioned him to be judicious with his disposal techniques, warning him not to "burn something that you will regret or that those who come after you may be in want of." Short also collected records of other family 
members. In the late $1830 \mathrm{~s}$, he obtained his deceased father's personal papers, and, following the death of William Short in 1849 , Dr. Short and his brother, Cleves, divided their esteemed uncle's personal correspondence, which included their letters to him. Dr. Short's personal papers, therefore, included both his letters to Uncle William and his uncle's letters in return. These letters document almost forty years. of family, personal, and career news of both men of historical note. In 1843, using his collection of family letters and other manuscripts, Dr. Short compiled a comprehensive narrative family history, which his daughter, Mary Churchill Richardson, maintained several years after the death of her parents. The history is a valuable record for today's researchers. 6

In addition to specific bequests and property settlements, Dr. Short endowed the scientific community with his pioneer work on the flora of Kentucky and its environs. In 1845 , he had remarked that future botanists would continue his work and that he wished to be remembered as one who unselfishly shared his plant collections and research and thereby increased the knowledge and promoted interest in the flora of his native region, although he failed to publish a book on the subject. Besides his relatively small number of published writings, Dr. Short's botanical legacy is embodied in his herbarium, plant specimens found in other preserved collections, and his botanical correspondence. For several years before his death, Short had been concerned about the disposition of his herbarium. He bequeathed it to the 
Smithsonian Institution and stipulated that it be preserved and open for research.7

The Smithsonian, however, refused the gift. On the advice of Asa Gray, the Short family donated the herbarium to the Academy of Natural Sciences in Philadelphia, in which Dr. Short had held membership. By the end of February, 1864, the collection, consisting of approximately 16,000 species, had arrived.at the academy. Elias Durand, curator of the academy's herbarium and Dr. Short's former acquaitance, assured William that his father's conditions of preservation and access for research would be met. He commented that the gift was the "most splended herbarium to be seen any where, for the good preservation and beauty of its specimens and for the admirable neatness and elegance of its arrangements." 8

Short's herbarium probably included the plant species he had discovered in Kentucky and consequently were named in his honor. Among them included Myosurus Shortii (now called Myosurus minimus), a buttercup family flower short found in Christian County, Kentucky, and named by Constantine S. Rafinesque in 1819; Aster Shortii, a wildflower Short discovered on the cliffs of the Kentucky River and described in his 1833 catalogue of Kentucky plants; Carex Shortiana, a sedge named for Short in 1836 by the New York botanist and sedge expert, Chester Dewey; Vesicaria Shortii, a plant in the mustard family, that short found along the Elkhorn Creek between Lexington and Frankfort, Kentucky, identified in his 1837 supplementary catalogue of Kentucky plants, and named by John Torrey; and Solidago Shortii, a goldenrod Short 
discovered on Rock Island, in the Ohio River near Louisville, Kentucky, and dedicated to him by Torrey and Asa Gray in 1842.9

One plant, however, was not represented in the herbarium. Dr. Short had died in 1863 with the fate of another namesake unknown. In 1839, Dr. Gray had dignified Short with the christening of a dried plant specimen, Shortia galacifolia, thereby naming a plant genus for his friend. At times short had doubted the existence of the plant or speculated that it was extinet, but he had continued to encourage botanical explorations in search of it. After Short's death, Gray identified another species of the genus, Shortia uniflora, whose native habitat was the mountains of Japan. This discovery and classification strengthened the possibility of finding Shortia galacifolia. Gray commented, however, that Dr. Short deserved "better commemoration" than the "empty name of a most obscure plant."10

In October, 1878, Asa Gray received news from Joseph W. Congdon, Providence, Rhode Island, of the possible rediscovery of Shortia galacifolia. George McQueen Hyams, the son of M.E. Hyams, a Statesville, North Carolina plant dealer, had located the plant. Congdon, who had received the plant specimen from the elder Hyams, forwarded the alleged Shortia galacifolia to Gray, who confirmed its identification. Dr. Gray expressed delight that his faith had been rewarded and confessed to a fellow botanist William M. "Canby that he considered the occasion more of a personal satisfaction than his 1878 election as a." 
corresponding member in the Institut de France, Academie des Sciences. Immediately after his confirmation of the plant's identity, Gray began making arrangements for a botanical trip to the North Carolina mountains and the site of the Shortia station, located about five miles north of Marion on the banks of the Catawba River in McDowell County. In June, $1879, \mathrm{Dr}$. Gray and a party of three other botanists were led by. Hyams and his son to his location. Here Gray saw the plant he had named forty years earlier with its evergreen leaves and dainty fringed-bell flowers, each attached to a slender, wiry stem. They searched for new stations, but found none. Soon thereafter, Dr. Gray wrote to Short's daughter that botanists around the world were delighted with the rediscovery of Shortia galacifolia, "perhaps the most interesting flower in North America."11

In 1884 elder Hyams reported to the United States National Herbarium that only ten Shortia galacifolia plants remained in the Catawba River station and he would not remove and sell these specimens for fear of the plant's extermination in its natural habitat. Two years later, however, Charles Sprague Sargent, the director of the Arnold Arboretum at Harvard Uniersity, and his guide, Frank E. Boynton of Highlands, North Carolina, came across the plant while searching the Jocassee Valley for Michaux's Magnolia cordata. This was an area in the mountains of South Carolina farther south than the earlier Shortia explorations. On this trip, they located Shortia galacifolia at the headwaters of the Keowee River near the confluence of the Horsepasture and 
Toxaway Rivers in Oconee County, North Carolina. Two months later, Boynton returned to the region and located other Shortia stations on Bearcamp Creek, a lower tributary of the Horsepasture River. In 1889 , he reported an abundance of the plant in the lower Jocassee Valley in Oconee County, South Carolina. In 1890, Thomas Grant Harbison, a botanist who later became director of the North Carolina Herbarium, located other Shortia stations along the Horsepasture River between its junction with the Toxaway River and Bearcamp Creek. These discoveries confirmed Shortia galacifolia's abundance and assured its preservation. This was the climax of almost fifty years of exploration for the lost Shortia. 12 After the plant's rediscovery and with its abundance certified, scientific interest in Shortia centered around the genus name. In 1907 Homer Doliver House replaced the genus name Shortia, Torrey and Gray, with the generic name, Sherwoodia, in honor of W.L. Sherwood, who cultivated the plant at his home in Highlands, North Carolina. House argued that in 1840 Constantine Samuel Rafinesque had given the name Shortia to a native Kentucky shrub, a fact which invalidated Gray's application of the name to a Carolina wildflower in 1842. In 1935, however, a committee appointed by the Sixth International Botanical Congress rejected the genus name Sherwoodia, House, and conserved the name, Shortia, Torrey and Gray. Rafinesque's plant is now called Arabis dentata. Although the generic name Shortia is commonly used for the North American species, the plant has had a variety of nicknames. Hyams sold it as "Hyams' Sparkling Shortia." By 
the turn of the century, it was called "Little Colt's Foot." Today, its most popular nickname is "Oconee Bells" because of its place of rediscovery and the shape of its flowers.13

The natural history of Shortia galacifolia reflects a common pattern of historical interest in its namesake. During the late nineteenth and early twentieth centuries, Dr. Short was not the subject of a full-length biography; several writers, however, published their personal reminiscenses about him. His former student and fellow plant explorer, Robert Peter, remembered his friend Short as a "most upright, conscientious, modest, undemonstrative gentleman" who was also "a most zealous and industrious botanist, and was possessed of artistic tastes and ability." Lewis Rogers, who succeeded Dr. Short in the chair of materia medica at the University of Louisville, also mentioned Dr. Short in an 1873 article on the history of medicine in Kentucky. Biographical sketches of short, of which considerable information appears to have gleaned from Gross's "Obituary Notice," appeared in such works as Appleton's Cyclopaedia of American Biography (1888) and Howard A. Kelly's Some American Medical Botanists (1914). The memoirs are valuable references to Short and medical history and education, but they are not analytical studies of Short's role in American medical education and his contribution to the study of botany, especially in the West. 14

As obscurity had hindered the investigation of Shortia galacifolia, insufficient historical evidence at that time hampered scholarly interest in Dr. Short. His personal 
papers, for example, had been scattered among family members. Eventually, several of Dr. Short's descendants, and others who had come into possession of his manuscripts, donated their collections to manuscript repositories. During the 1930s, the two largest collections of Charles Wilkins Short Papers were made available for research and preserved for future generations. 14

The, Filson Club, in Louisville, Kentucky, holds the largest collection of Charles Wilkins Short Papers, which spans the subject's lifetime: and includes various types of records, including family, business, and botanical correspondence; financial records; land papers; reports of medical cases from Short's practice in Hopkinsville, Kentucky; a diary; botanical drawings; a catalog of collected, preserved, and distributed plants; and his memoranda of in-coming and out-going letters from 1816 to 1860. The manuscript collection illustrates Dr. Short's methodical and meticulous manner and the donors' appreciation for their preservation and use. Chief benefactors of the Filson Club collection of Charles Wilkins Short Papers were Dr. Short's granddaughter, Jane Short Butler Courtenay (1853-1938); her grandson, Alexander Fible Courtenay (1922- ); Dr. Short's granddaughter, Mary Churchill Short (1860-1937); and great-granddaughter, Ludie Kinkead (1882-1970), who was curator of the Filson Club from 1923 to 1952.15

During this same time period, another descendant, Annie Allen Richardson (1854-1937), donated her Grandfather 
Short's papers to the Southern Historical Collection at the University of North Carolina, Chapel Hill. Beginning in the 1920s, Professor James G. deRoulhac Hamilton, head of the university's history department, aggressively sought manuscript collections that documented all periods and topics of the South primarily to serve the school's graduate history program. In 1930, Dr. Hamilton's acquisitions, in addition to other manuscript collections relating to the South already in the school's library, were incorporated in the establishment of the Southern Historical Collection, which remains a principal repository of primary resources on the history of the South. Through Professor Hamilton's efforts, Miss Richardson's collection of family papers went to this North Carolina repository. 16

Other descendants have demonstrated their interest in the extended Short family. In 1944, for example, Charles Wilkins Short, a grandson of John Cleves Short, sold the Papers of the Short, Harrison, and Symmes Families, a collection of approximately 10,000 items, to the manuscript division of The Library of Congress. The William Short (1759-1849) Papers, which consist of approximately 20,000 items, are also housed in the same repository. Another collection of William Short Papers is available in the archives of the College of William and Mary. The donors of this collection included three children of Dr. Short's son William: Mary Churchill Short (1860-1937), Fanny Short Butler (1864-1930), and William Short (1848-1930). Dr. John W. Price and his wife, Barbara Atwood, whose grandmother was 
Dr. Short's daughter, Jane, also donated their William Short Papers to her ancestral uncle's alma mater. 17

Fortunately, other family members have also made their collections accessible for research. Caroline Price Reid and Mary Butler Tracy Wessel, both great-great granddaughters of Dr. Short and descendants of Jane Short Butler, recently donated or loaned for microfilming to the University of Louisville Archives and the Filson Club their Short and other related family manscripts. Dr. Thomas C. Courtenay, a Louisville physician and great-great grandson of Short and a descendant of the Butler branch, is a family historian. Besides his small but impressive manuscript collection, much of which he has acquired from relatives, Dr. Courtenay owns a painting of Hayfield (ca. 1850s), the James Reid Lambdin portrait of Dr. Short (ca. 1834), daguerreotypes of Dr. and Mrs. Short (ca. 1850s), Dr. Short's secretary and other family furniture, and books from Short's library. Dr. Courtenay, who refers to Dr. Short as "Grandpa," also was graduated from the University of Pennsylvania medical school. 18

The various collections of Charles Wilkins Short Papers now in archival repositories remained in private hands at least until the 1930s. Although the collections have received scholarly attention, Dr. Short, nevertheless, was more widely recognized by his contemporaries than by twentieth-century historians. The indifference of historians to study American science probably contributed to the obscurity of Dr. Short, as well as many of his scientific 
colleagues and successors. In 1946, the distinguished historian, Arthur M. Schlesinger, Sr., observed that, for the most part, during the late nineteenth and twentieth centuries scientists and popular writers pursued the study of the history of American science and technology, while historians devoted their writings to political and military history. In 1966, A. Hunter Dupree, a Schlesinger student and eminent historian of science, noted that after World War II, research interest in the history of American science was influenced by the prevailing belief that one had to be a scientist to study and write about science. He argued, however, that the history of science was social history, the study of scientists, and therefore, worthy of inquiry and analysis by historians. Only in the past several decades have historians taken up the Schlesinger and Dupree charge. 19

Short, furthermore, was not as colorful or controversial as his colleagues, such as Daniel Drake and Charles Caldwell, both subjects of wider historical interest thus far. Dr. Short's contributions to medical education in the West and his study of the flora of Kentucky, however, have received passing attention in institutional histories and publications on subjects related to him and his work. In his biography of Asa Gray, for example, Dupree referred to Short as "a pillar of medical education in Kentucky and a distinguished local collector." Ronald L. Stuckey, an Ohio State University botanist noted for his writings on the history of science, recently edited a volume of Dr. Short's publications, which perhaps signifies an interest in short's 
scientific contributions during the early nineteenth century. Although the book's format may have been directed by the publisher, the volume suffers from little editing, a sparse biographical sketch, no pagination, deletion of Short's writings on medicine, and copies of publications that are faded to obscurity in various passages. Physician Frederick Eberson included Dr. Short among nine biographical sketches in his recently-published Early Physicians of the West. Although Dr. Eberson consulted several of Short's published writings as well as secondary sources, he cites only one manuscript in his bibliography. 20

In the 1940s, at least two writers traced the life of Dr. Short and his career as a pioneer Kentucky botanist and medical educator. Irving Frederick Ahlquist's 1947 doctoral dissertation, "Ohio Valley Culture as Reflected in the short Family, 1790-1860," written under the direction of Professor James G. Randall at the University of Illinois, described the social and intellectual influences and contributions of Peyton Short and his two sons in Kentucky and Ohio. Ahlquist portrayed the Shorts as offspring and purveyors in the pioneer West of the established Virginian aristocratic, cultured society. The dissertation provides detailed biographical accounts of Peyton Short and his sons, John Cleves and Charles Wilkins Short. 21

Percy Albert Davies, a former professor and chairman of the biology department at the University of Louisville, was another biographer of Charles Wilkins Short. On June 7 , 1943, he delivered a paper on his university predecessor, 
Dr. Short, to members of the Filson Club. Two years later, his lecture appeared as an essay in the club's history journal. It included an extensive inventory of the short Papers in the Filson Club, library books and pamphlets from Short's library at the University of Louisville, a listing of Short's incoming correspondence located in several repositories and private collections, and an annotated bibliography of Dr. Short's published writings. Like the Ahlquist dissertation, Professor Davies' biographical essay and bibliography are valuable references on the pioneer Kentucky botanist. 22

Davies planned to publish a biography of Short and decided to devote one chapter of the book to the story of Shortia galacifolia. By the mid-1950s, however, Professor Davies had two books in progress: the biography of short and the story of Shortia. At the time of his death in 1961, Davies was still collecting research material for the volumes, yet had drafts of most chapters, and had published several articles about Shortia galacifolia. 23

As Professor Davies' research continued on the history of Shortia, he devoted more and more time to the scientific study of the plant. In both March and May, 1951, Davies visited the Carolina mountains where he located various Shortia stations. Atland T. Hotchkiss, also a biology professor at the University of Louisville, accompanied Davies on the May trip. At the confluence of the Toxaway and Horsepasture rivers, they found an abundance of Shortia. Hotchkiss later recalled that they had explored for 
the plant along the small streamlet tributaries of both rivers. He remembered that "Shortia appeared to be restricted to the near margins of the larger streams; the smaller streamlets were without Shortia but whenever there were springs coming down the steep hillsides there were abundant remains of old stills falling into decay."24

With the aid of other distribution studies, plus his own findings, Davies charted two general areas where Shortia thrived in its natural habitat. One area encompassed Oconee and Pickens Counties, South Carolina; Transylvania and Macon Counties, North Carolina; and Rabun Gap, Georgia. The second area was in McDowell and Burke Counties, North Carolina. He gathered plant specimens along the Keowee River in Oconee County and compared them with plants from the banks of the Catawba River in McDowell County. Because of the distinct floral variations in the two Shortia plants, Dr. Davies considered the Keowee River specimen typical of the species and established a new variety, brevistyla, for the plant found along the Catawba River. 25

For the next three years, Professor Davies continued to study the geographical distribution and abundance of Shortia galacifolia. Although similar studies had been undertaken by a few botanists, no compilation of information had resulted. Davies made several extensive expeditions to North Carolina, South Carolina, and Georgia to study the natural habitat of Shortia and corresponded with botanists of the locality. When a free lance writer from North Carolina asked the professor for information to use in a popular 
article, the writer was advised to wait and read Davies' forthcoming essay about Shortia galacifolia. Dr. Davies added that he had searched for Shortia along the rivers and creeks of North and South Carolina and because of this and his "collection of more than 1,000 references," he considered himself an expert on Shortia. 'Professor Davies' 1955 article, "Distribution and Abundance of Shortia Galacifolia," located numerous Shortia stations in North Carolina, South Carolina, and Georgia. He found the plant in great abundance, especially along the cool, damp, shady banks of rivers and streams, which disproved the notion of Shortia's scarcity. Today, however, North Carolina and Georgia list Shortia galacifolia among their plants that are rare or in danger of extinction. Its collection and sale are regulated by state law. 26

Davies was also interested in the broad geographical distribution of the genus Shortia and the narrowly restricted range of each species. His studies compared the galacifolia species and its natural habitat of the southern section of the Blue Ridge Mountains, the Japanese and Formosan species, uniflora, and the senemis species of southwestern China. In 1953 and 1954 Davies corresponded with Leopold A. Charnette, an American Air Force sargeant stationed in Japan, and with Charnette's friends, two Toyko University professors, about the species Shortia uniflora and it's varieties. Although Davies charted the origin, evolution, and migration of the genus and its species, he discovered no clue that suggested the antiquity of the genus. The first record of the American 
species' existence was the type specimen (the individual plant on which the original scientific description of a species is based) gathered by André Michaux in 1787.27

Following his 1886 trip to the Carolina mountains, in which he had traced Michaux's route, Charles Sprague Sargent theorized that the type location (the place where the type specimen was collected) of Shortia galacifolia was at the junction of. the Horsepasture and Toxaway Rivers. In 1947 the botanist Alton E. Prince challenged Sargent's claim. Prince explored further south than Sargent to the junction of the Whitewater and Toxaway Rivers. He determined that this junction was the exact fork of the Koewee River or "the head of the Kiwi" (Keowee) as Michaux had described. Based on his extensive research and Shortia expeditions, Dr. Davies concurred with Prince's description of the type location. After studying Michaux's journal, Davies speculated further that Michaux had gathered Shortia from the Keowee River location twice, on his first trip in June, 1787, and again in 1788. In 1955 Davies published these findings in an article entitled, "Type location of Shortia Galacifolia."28

Davies was later given reason to believe that the natural boundaries of Shortia galacifolia extended into Virginia. A Shortia station near Lynchburg had been discovered by Dorothy L. Crandall, professor of biology at Randolph-Macon Women's College. After visiting the site, however, Professor Davies concluded that the station was not a natural one. He believed that the plants had been transplanted from a Keowee River station.29 
After pinpointing the restricted range of the American species of Shortia, Davies became interested in its pollination and seed production. Unlike the Shortia uniflora he found the American species difficult to propagate, because the seed nearly always failed to germinate. During the 1950s, he corresponded with many persons, both professional and amateur botanists, who had successfully germinated the seeds. One. correspondent, Samuel K. Roller of Lynchburg, Virginia, exchanged information with Davies about the plant's germination and growth. After learning that Professor Davies had been unsuccessful in his attempts to germinate Shortia, Roller asked the botanist if he were familiar with Edwin F. Sheffak's book, Wild Flowers and How to Grow Them. In 1958 Davies successfully germinated the plant in a terrarium. The final years of his research were devoted to the germination of the plant and the study of the dispersal of its seeds. After corresponding with others who had successfully germinated the plant and after visiting numerous stations, Dr. Davies concluded that one reason for the restricted range of Shortia galacifolia, Torrey and Gray, was its insufficient seed production. He also discovered that the principal method of pollination was by insects, particularly the honey bee. 30

The natural history of Shortia galacifolia, therefore, provides a link between Charles Wilkins Short and Percy Albert Davies, both University of Louisville professors and Kentucky botanists. The story of the discovery, quest, and rediscovery of the plant parallels general trends in 
nineteenth-century science, when the botanist's chief interest was to identify and classify plants. By the mid-twentieth century, scientists such as Davies continued the study of natural history through research on the abundance, distribution, reproduction, and evolution of plants.

Other vestiges are reminders of Short's public and private life. Today, several landmarks commemorate Dr. Short's life, activities, and influence in the Louisville area. The estate, Hayfield, is a physical and community symbol of his wealth, cultured traits, and love of nature. One of Short's friends once remarked that the short family had furnished their home "in the best Kentucky style." Several engravings of Dr. Short's favorite author, Sir Walter Scott, had adorned the interior walls of Hayfield, and books by the same writer were placed on tables for ready reference. Elm trees had surrounded the dwelling, which was flanked at one side by a garden of several acres, where Dr. Short had personaliy cultivated domestic and foreign plants and shrubs, and at the rear of the structure stood a beautiful timberland. The farm of several hundred acres comprised the remainder of the estate. 31

Following her husband's death in March, 1863, Mary Churchill Short returned to Hayfield, where she lived about one year. In 1864, Mrs. Short sold the estate and moved to Louisville, where she lived with her daughter Lucy Kinkead and family" for six years. She died in 1870.32

Hayfield has undergone several transformations since 
the Shorts' ownership. In 1940, the house underwent major alterations, which included interior and exterior changes; the house, however, retained its Greek Revival design. In. the 1960s, a stone wall, slave quarters, and a stone springhouse, which according to one partaker had emitted "the coldest and most limpid water," were razed for the construction of new homes in the Hayfield subdivision. The Hayfield mansion has been the home of other well-known Louisvillians, including George Danforth, who operated a cattle farm there during the late nineteenth century; Robert Tyler, a business executive; H.G. Whittenberg, Sr., a Iand developer; and most recently, local attorney Henry Triplett. Today, Hayfield appears on the National Register of Historic Places. 33

Finally, Dr. Short's gravesite is a lasting tribute to his memory. Befitting his image as family patriarch, Short's grave in Louisville's Cave Hill Cemetery is surrounded with monuments bearing the names of his descendants. From its origins in 1848 as a rural cemetery to the present, Cave Hill has been more than a burial ground for the city's affluent citizens and Civil War soldiers. Through planned development, the cemetery is a wildife preserve and arboretum nestled in a beautifully-landscaped, tranquil setting. Cave Hill is an appropriate site for the Kentucky botanist's grave. 34

Dr. Short's legacy is far-reaching. He was a conveyor of his family heritage and many of his descendants have recognized and fostered their family tradition. An 
appreciation of the arts, an emphasis on education, the practice of well-mannered, orderly living, and a sense of family and community responsibility marked the short character. As a country doctor, Short lived a less glamorous lifestyle while he served human needs on the Kentucky frontier. As a medical educator, he transmitted his knoweledge and craft derived from formal training and practical experience to hundreds of aspiring physicians. He also taught in two of Kentucky's oldest medical schools, one of which survives today. Dr. Short's botanical work, furthermore, brought him enduring recognition from contemporary naturalists and his scientific successors. Through scientific publications in addition to his correspondence and botanical exchanges with almost 100 persons interested in science, he promoted the study of botany, and especially the flora of his native region. Taxonomists still refer to Short's catalog of Kentucky flora and his plant specimens are available for research in American and European herbaria. Dr. Short's descendants, who include family members, educators, physicians, and botanists, are heirs of his endeavors and accomplishments and conduits of his legacy. 


\section{NOTES TO CHAPTER VI}

1 Asa Gray, "Charles Wilkins Short," in Scientific Papers of Asa Gray Selected by Charles Sprague Sargent, 2 vols. (Boston: Houghton, Mifflin, and Co., 1889), 2: 312-314; DSB 5: 511-514; DAB, 12: 626; Louisville Daily Journal, March 18, 1863, p.3.

${ }^{2}$ S.D. Gross, "Obituary Notice of Charles Wilkins Short, M.D.," Proceedings of the American Philosophical Society 10 (November 1865): 171-186. Reprinted and repaginated as Biographical sketch of Charles Wilkins Short, M.D. (Philadelphia: Collins, 1865); DAB, 8: 18-20, Gross to Mary Short, December 23, 1863, Charles Wilkins Short Papers, Southern Historical Collection, University of North Carolina, Chapel Hill, North. Carolina (hereinafter SPSHC); Gross to Joseph B. Kinkead, October 18, 1865, Charles Wilkins Short Papers, American Philosophical Library, Philadelphia, Pennsylvania (hereinafter SPAPS); Gross to M. Short, January 10,1866 , SPAPS.

3 Gross, "Obituary Notice of C.W. Short," p. 178 . In his sketch, Gross refers to Short's birthplace and childhood home as "Greenville" rather than "Greenfield" ( $p .171$ ) and he notes that when short was a medical student he studied privately with Dr. Caspar Wistar (p. 172). To the contrary, Short had been the private pupil of Nathaniel Chapman. The James Reid Lambdin portrait of Dr. Short is owned by Dr. Thomas A. Courtenay, Simpsonville, Kentucky.

${ }^{4}$ Charles Wilkins Short, Will, Will Book 6, p. 70 , Jefferson County, Office of the County Clerk, Louisville, Kentucky.

${ }^{5}$ Charles Wilkins Short, Will, Will Book $6, p .70$, Jefferson County, Office of the County Clerk, Louisville, Kentucky; P. Albert Davies, "Charles Wilkins Short, 1794-1863: Botanist and Physician," Filson Club History Quarterly 19 (July 1945): 208-209, 213 .

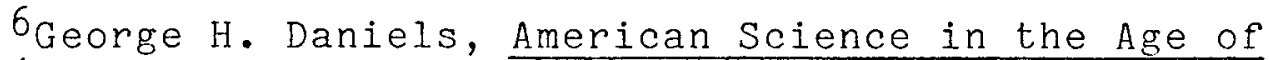
Jackson (New York: Columbia University Press, 1968), p. 87; Charles Wilkins Short to John Cleves Short, September 13, 1850, Short, Harrison, and Symmes Family Papers, Library of Congress, Washington, D.C., microfilm in the Filson Club (hereinafter SHSLC); J.C. Short to C.W. Short, March 13, 1838, June 3, 1838, December 27, 1857, SHSLC; C.W. Short and Mary Churchill Richardson, "A Chronological Record of the Families of Charles Wilkins Short and Mary Henry Churchill, 1843, 1879", Charles Wilkins Short Papers, Filson Club, Louisville, Kentucky (hereinafter SPFC). 
7C.W. Short to Asa Gray, December 25, 1845, Asa Gray Papers, Gray Herbarium Library, Harvard University, Cambridge, Massachusetts (hereinafter AGHU); Charles Wilkins Short, Will, Will Book 6, p. 70, Jefferson County, Office of the County Clerk, Louisville, Kentucky.

${ }^{8}$ Gray to William Short, November 14,1863 , SPSHC; Elias Durand to w. Short, February 24, 1864, SPSHC; DAB, 5:538-540; Davies, "Charles Wilkins Short, 1794-1863," p. 153 .

${ }^{9}$ C.S. Rafinesque, "Notice on the Myosurus Shortii," American Journal of Science 1 (1819): 378-380; [Charles Wilkins Short, Robert Peter, Henry A. Griswold], "A Catalogue of the Native Phaenogamous Plants, and Ferns of Kentucky," Transylvania Journal of Medicine and the Associate Sciences 6 (July-September 1833): 491; William Jackson Hooker, Flora-Boreali Americana; or, The Botany of the Northern Parts of British America, 2 vols. (Weinheim, Germany: J. Cramer, 1960; originally published 1829-1840), 2: 9; [Short and Robert Peter], "A Second Supplementary Catalogue of the Plants of Kentucky, "Transylvania Journal 8 (October-December 1835): 576; C[hester] Dewey, "Caricography," American Journal of Science 30 (July 1836): 60; Short, "A Third Supplementary Catalogue of the Plants of Kentucky," Transylvania Journal 10 (July-September 1837): 339; John Torrey and Asa Gray, A Flora of North America, 2 vols. (New York: Hafner Publishing Co., 1969; Originally published 1838-1843), 1: 102; 2: 222; DAB, 5: 267-268; DSB, 6: $492-495$.

10 John Torrey to C.W. Short, July 12, 1839, Botanical Correspondence, vol. 3, SPFC; Constantine S. Rafinesque to C.W. Short, November 20, 1819, File 134, SPFC; C.W. Short to Torrey, January 31, 1852, March 22, 1852, John Torrey Papers, New York Botanical Garden Library, Bronx, New York (hereinafter NYBG); John Carey to C.W. Short, March 18, 1852, SPSHC; Gray, "Shortia, Torr. and Gray, and Schizocodon, Sieb. and Zucc., Identical," American Journal of Science, 2d ser. 55 (May 1868): 402-403; Gray, "Reconstruction of the Order Diapensiaceae," Proceedings of the American Academy of Arts and Sciences 8 (June 1870): 243-247.

11 Joseph W. Congdon, "Rediscovery of Shortia," Bulletin of the Torrey Botanical Club 6 (October 1878): 266; Gray to William M. Canby, October 28, 1878, in Jane Loring Gray, ed., The Letters of Asa Gray, 2 vols. (New York: Lenox Hil1, 1973; originally published 1893), 2: 682-683; Gray, "Shortia Galacifolia Re-discovered," American Journal of Science and Arts, 3d ser. 16 (1878): 483-185; John H. Redfield, "Notes on a Botanical Excursion into North Carolina," Bulletin of the Torrey Botanical Club 6 (July-August 1879): 331-339; Gray to a daughter of Dr. Short, August 5, 1879, SPSHC. 
12M.E. Hyams to John Donnell Smith, May 3, 1884 , transcription in Box 5, File 4, Percy Albert Davies Papers, University of Louisville Archives (hereinafter DPULA); C[harles] S. Sargent, "Some Remarks Upon the Journey of André Michaux to the High Mountains of North Carolina, in December 1778, in a letter addressed to Professor Asa Gray," American Journal of Science, 3d ser. 32 (December 1886): 466-473; Sargent, "The Story of Shortia." Garden and Forest 1 (December 1888): 506-507; Frank E. Boynton," The Home of Shortia," Garden and Forest 2 (May 1889): 214-215; W.N. Clute, "The Romance of the Oconee Bells," The American Botanist 32 (April 1926): 66-68; P.A. Davies, 'Geographical Variations in Shortia Galacifolia," Rhodora 54 (May 1952): $121-124$.

13Homer Doliver House, "The Genus Shortia," Torreya 7 (1907): 233-234; C.S. Rafinesque, Autikon Botanikon (Ann Arbor: Edward Bros., 1942; originally published 1815-1840), pp. 16-17; Hui-Lin Li, "On the Sino-Himalayan Species of Shortia and Berniuxia," Rhodora 45 (September 1943):

333-337; "Additional Nomina Generica Conservanda (Pteridophyta and Phanerogamae), Kew Bulletin, No. 3 (1940): 118; Charles F. Jenkins, "Asa Gray and His Quest for Shortia Galacifolia," Arnoldia 2 (April 1942): 28; Davies, "Story of Shortia," Box 6, File 2, DPULA.

14 Robert Peter, The History of the Medical Department of Transylvania University, Filson Club Publication No. 20 (Louisville, Ky.: John P. Morton \& Co., 1905), pp. 78-82; DAB, 14: 499-500; Lewis Rogers, "Facts and Reminiscences of the Medical History of Kentucky," The American Practitioner 7 (April 1873): 193-222; James Grant Wilson and John Fiske, eds., Appleton's Cyclopaedia of American Biography, 6 vols. (New York: Pickering-Sumter, D. Appleton and Co., 1888), 5: 5; Howard A. Kelly, Some American Medical Botanists Commemorated in our Botanical Nomenclature (Troy, New York: The Southworth Co., 1914), pp. 129-135.

15Davies, "Charles Wilkins Short, 1794-1863," pp. 208-209; "Memorial Resolution for Ludie J. Kinkead," The Filson Club History Quarterly 45 (April 1971): Page insert preceding p. 145 .

16 Inventory to the Charles Wilkins Short Papers, SPSHC; Carolyn Andrews Wallace, "The Southern Historical Collection," The American Archivist 28 (July 1965): $427-436$.

17 Inventory to the Papers of the Short, Harrison, Symmes Families, SHSLC; Inventory to the William Short Papers, Manuscript Division, Library of Congress; Inventory to the William Short Papers, Earl Gregg Swem Library, College of William" and Mary, Williamsburg, Virginia.

${ }^{18}$ Short Family Papers, Microfilm Project 79 , 
University of Louisville Archives, Louisville, Kentucky (hereinafter ULA); John Russell Butler Diaries, Microfilm Project 88, ULA; Interview with Dr. Thomas C. Courtenay, October 11, 1979, Simpsonville, Kentucky.

19 Arthur M. Schlesinger, Sr., "An American Historian Looks at Science and Technology," Isis 36 (October 1946): 162-166; A. Hunter Dupree, "The History of American Science--A Field Finds Itslef," The American Historical Review 71 (April 1966): 865, 869,874.

20Emmet Field Horine, Daniel Drake (1785-1852): Pioneer Physician of the Midwest (Philadelphia: University of Pennsylvania Press, 1961); Henry D. Shapiro and Zane L. Miller, eds., Physician to the West: Selected Writings of Daniel Drake on Science and Society (Lexington: The University Press of Kentucky, 1970); Horine, Biographical Sketch and Guide to the Writings of Charles Caldwell (Brooks, Ky.: High Acres Press, 1960.); Nellie Carstens, "Charles Caldwell, A Biographical Sketch" (M.A. thesis, University of Louisville, 1979); John D. Wright, Translyvania: Tutor to the West (Lexington, Ky.: Translyvania University, 1975), p. 150; Kentucky Writers' Project of the Works Projects Administration, A Centennial History of the University of Louisville (Louisville, Ky.: University of Louisville, 1939), pp. 42-43; A. Hunter Dupree, Asa Gray, 1810-1888 (New York: Atheneum, 1968; originally published 1959), p. 63; Ronald L. Stuckey, ed., Scientific Publications of Charles Wilkins Short (New York: Arno Press, 1978); Frederick Eberson, Early Physicians of the West (St. Petersburg, Florida: Valkyrie Press, Inc., 1979), pp. 79-88.

21 Irving Frederick Ahlquist, "Ohio Valley Culture as Reflected in the Short Family, 1790-1860" (Ph.D. dissertation, University of Illinois, 1947).

$131-155,208-249$.

22 Davies, "Charles Wilkins Short, 1794-1863," pp.

23 Davies to Arthur B. Massey, June 26, 1952, Box 1, File 4, DPULA: Davies to J.J. Oppenheimer, May 28, 1956, Record Group 20, College of Arts and Sciences, Faculty Personnel Records, 1940s-1960s, Box 2, ULA; Percy Albert Davies Papers, ULA.

24 Davies, "Geographical Variations in Shortia Galacifolia," Rhodora 54 (May 1952): 121-124; Arland T. Hotchkiss to the author, December 7, 1982.

25 Davies to Ashton Chapman, May 15, 1953, Box 1, File 4, DPULA; Jenkins, "Asa Gray and His Quest for Shortia Galacifolia," pp. 25-26; Wilbur H. Duncan, G.W. McDowell, and Haskell Vernard, "Shortia Galacifolia from Georgia," Rhodora 52 (October 1950): 229-232; Davies, "Geographical Variations in Shortia Galacifolia," pp. 121-124. 
26 Jenkins, "Asa Gray and His Quest for Shortia Galacifolia," pp. 24-26; Duncan, McDowell, and Vernard, "Shortia Galacifolia from Georgia,' pp. 229-230; Correspondence, Shortia, 1948-1953, Box 1, Files 4, 5, DPULA; Davies' Tripbooks, 1952-1954, DPILA; Davies to Chapman, May 25, 1953, Box 1, File 4, DPULA; Davies, "Distrubution and Abundance of Shortia Galacifolia," Rhodora 57 (July 1955): 189-201; J.R. Massey to the author, May 27, 1982; General Statutes of North Carolina, sec. 106-202.12 to 106-202.19; Official Code Book of Georgia, Title 12-6-170 to 12-6-176.

27 Davies, "History of the Distribution of Shortia," typescript, DPULA; Davies, "Type Location of Shortia," typescript, DPULA; Leopold A. Charnette to Davies, March 28, 1953, Box 1, File 6, DPUlA; Davies to Charnette, November 2, 1954, Box 1", File 6, DPULA; DSB, 9: 365-366.

${ }^{28}$ Sargent, "Some Remarks Upon a Journey of André Michaux," pp. 466-473; Alton. E. Prince, "Shortia Galacifolia in Its Type Location," Rhodora 49 (June 1947): 159-161; Davies, "Type Location of Shortia Galacifolia," Castanae 21 (September 1956): 107-112.

29 Dorothy L. Crandall, "Shortia Galacifolia in Gray's Manual Range," Rhodora 58 (February 1956); 38-40; Davies to Cranda11, March 20, 1957, DPULA: Davies, "Remarks on the Virginia Location of Shortia Galacifolia," Rhodora 61 (December 1959): 297-301.

30 Correspondence re Shortia, 1957-1958, DPULA; Charnette to Davies, July 3, 1954, Box 1, File 6, DPULA; Samuel K. Roller to Davies, May 14, 1957, Box 1, File 10, DPULA; Davies, "Pollution and Seed Production in Shortia Galacifolia," Castanea 25 (September 1960): 89. $180-182$.

${ }^{31}$ Gross, "Obituary Notice of C.W. Short," pp. 176 ,

${ }^{32}$ Short and Richardson, "A Chronological Record of the Families of Charles Wilkins Short and Mary Henry Churchill," p. 194, SPFC.

33 Gross, "Obituary Notice of C.W. Short," p. 176; National Register of Historic Places Inventory, Nomination Form for Hayfield, April 22, 1980, Louisville Landmarks Commission, Louisville, Kentucky; City of Louisville, Community Development Cabinet, "Louisville Survey, East Report," October, 1979, pp. 132-133.

${ }^{34}$ Charter, By-Laws and Rules and Regulations of Cave Hill Cemetery Co. and Charter of Cave Hill Investment Co. (Louisville, Ky.: Courier-Journal Job Printing Co., 1901), pp. $29-48$. 


\section{BIBL IOGRAPHY}

\section{PRIMARY MATERIALS}

Books

John Q. Anderson, ed. Louisiana Swamp Doctor: The Writings of Henry Clay Lewis, alias "Madison Tensas, M.D." Baton Rouge: Louisiana state University Press, 1962 .

Barton, William P.C. Compendium Florae Philadelphicae: Containing a Description of the Indigenous and Naturalized Plants within a Circuit of Ten Miles around Philadelphia. 2 vols. Philadelphia: M. Carey and Son, 1818 .:

Bond, Beverly $W$. The Correspondence of John Cleves Symmes. New York: Macmillan Co., 1926.

Carter, Clarence Edwin, et al., eds. The Territorial Papers of the United States. 28 vols. to date. Washington, D.C.: Government Printing Office, 1934-1975.

Casseday, Ben. The History of Louisville from Its Earliest Settlement Till the Year 1852. Louisville, Ky.: G.R. Clark Press, 1970; originally published, 1852 .

Charter, By-Laws and Rules and Regulations of Cave Hill Cemetery Company and Charter of Cave Hill Investment Company. Louisville, Ky.: Courier-Journal Job Printing Co., 1901.

Collins, G. The Louisville Directory for 1838-9. Louisville, Ky.: J.B. Marshall, 1838 .

- The Louisville Directory for 1841. Louisville, $\mathrm{Ky} .:$ Logan \& Co., 1841.

- The Louisville Directory for the years 1843-1844. Louisville, Ky.: A.S. Tilden, 1843.

Darlington, William. Flora Cestrica: An Attempt to Enumerate and Describe the Flowering and Filicoid Plants of chester county, in the state of Pennsylvania. West Chester, Pa.: S. Siegfried, 1837 .

Early Proceedings of the American Philosophical Society, 1744-1838. Philadelphia: McCalla \& Stavely, 1884.

Eaton, Amos. Manual of Botany for North America. 7 th ed. 
Albany, N.Y.: Oliver Steele, 1836 .

Gray, Asa. Gray's Manual of Botany. Edited by Merritt Lyndon Fernald. Cambridge, Mass.: Harvard College, 1950 ; originally published 1848 .

Gray, Jane Loring, ed. Letters of Asa Gray. 2 vols. New York: Lenox Hill, 1973; originally published 1893.

Gross, Samuel D. Autobiography. 2 vols. Philadelphia: Georgie Barrie, 1887 .

Haldeman's Picture of Louisville. Directory and Business Advertiser for 1844-1845. Louisville, Ky.: W.N. Haldeman, 1844 .

Hooker, William Jackson. Flora Boreali-Americana; or, The Botany of the Northern Parts of British America. 2 vols. Weinheim, Germany: J. Cramer, 1960; originally published 1829-1840.

Hopkins, James F. et al., eds. The Papers of Henry Clay. 5 vols. to date. Lexington, Ky.: The University Press of Kentucky, 1959-1973.

Kentucky $i \frac{\text { Acts of the General Assembly }}{18-1820}, 1817-1818$,

McMurtrie, Henry. Sketches of Louisville and Its Environs. Louisville, Ky.: G.R. Clark Press, 1968; originally published 1819 .

Nuttall, Thomas. The Genera of North American Plants. 2 vols. Philadelphia: D. Heartt, 1818.

Peter, Robert. The History of the Medical Department of Transylvania University. Louisville, Ky.: John P. Morton \& Co., 1905.

and Peter, Johanna. Transylvania University: Its Origin, Rise, Decline, and Fall. Louisville, Ky.:

Rafinesque, $C$ [onstanstine] S. Autikon Botanikon. Ann Arbor: Edward Bros., 1942; originally published 1815-1840.

- A Life of Travels and Researches in North America and South Europe, or Outlines of the Life, Travels and Researches. Philadelphia: F. Turner, 1836.

Sargent, Charles Sprague, ed. Scientific Papers of Asa Gray. 2 vols. Boston: Houghton, Mifflin and Co., $188 \overline{9}$.

Shapiro, Henry D. and Miller, Zane L., eds. Physician to the West, Selected Writings of Daniel Drake on 
Science and Society, Lexington, Ky.: The University Press of Kentucky, 1970 .

Stuckey, Ronald L., ed. Scientific Publications of Charles Wilkins Short. New York: Arno Press, 1978.

Thomas, Samuel W. and Conner, Eugene H., eds. The Journals of Increase Allen Lapham for 1827-1830. Louisville, Ky.: G.R. Clark Press, 1973.

Torrey, John and Gray, Asa. A Flora of North America. 2 vols. New York: Hafner Publishing Co., 1969; originally published 1838-1843.

U.S. Department of Commerce. Bureau of the Census. Fourth Census of the United States, 1820. Christian County, Kentucky.

- Fifth Census of the United States, 1830. Fayette County, Kentucky.

- Sixth Census of the United States, 1840. Jefferson County, Kentucky.

- Seventh Census of the United States, 1850.

Jefferson County, Kentucky.

- Eighth Census of the United States, 1860.

Jefferson County, Kentucky.

Articles, Pamphlets, and Poems

"Additional Nomina Generica Conservanda (Pteridophyta and Phanerogamae.)" Royal Botanic Gardens, Kew, Bulletin of Miscellaneous Information 3 (1940): $81-134$.

The American Medical Recorder. 14 (July 1828): 163-164.

Baily, W.W. "To the Editor of Garden and Forest." Garden and Forest 2 (1889): 34 .

Boynton, Frank $\mathrm{E}$. "The Home of Shortia." Garden and Forest 2 (May 1889): 214-315.

Braun, E. Lucy. "A New Locality for Solidago Shortii." Rhodora 43 (October 1941): 484 .

Canby, William M., ed. "An Autobiography and Some Reminiscences of the Late August Fendler." Botanical Gazette 10 (June-August 1885): 282-290, 301-304, 319-322. 
Catalogues of the Louisville Medical Institute. Sessions $1839-1845$.

Catalogues of the Medical Department of Transylvania University. Sessions 1828, 1829, 1831, 1833, 1837 .

Coker, William C., ed. "Letters from the Collection of Dr. Charles Wilkins Short." Journal of the Elisha Mitchell Scientific Society 57 (July 1941): 98-168.

Congdon, Joseph W. "Rediscovery of Shortia." Bulletin of the Torrey Botanical Club 6 (october 1878): 266 .

Crandal1, Dorothy L. "Shortia Galacifolia In Gray's Manual Range." Rhodora 58 (February 1956): 38-40.

Davidson, R. An Excursion to the Mammoth Cave and the Barrens of Kentucky, with Some Notices of the Early Settlement of the State. Philadelphia: Thomas, Cowper-Thwait, and Co., 1840.

Davies, P.A. "Distribution and Abundance of Shortia Galaciofolia." Rhodora 57 (July 1955): 189-201.

- "Geographical Variations in Shortia Galacifolia." Rhodora 54 (May 1952): 121-124.

- "Pollinatino and Seed Production in Shortia Galicifolia." Castanea 25 (September 1960): 89-96.

- "Remarks on the Virginia Location of Shortia Galacifolia." Rhodora 61 (December 1959): 297-301.

- "Type Location of Shortia Galacifolia." Castanea 21 (September 1956): $107-112$.

- "An Unpublished Rafinesque Letter." Filson Club History Quarterly 23 (July 1949): 199-201.

Dewey, C[hester]. "Caricography." American Journal of Science and Arts 30 (July 1836): 59-64.

Duncan, W.H.; McDowell, G.W.; and Venard, Haskell. "Shortia Galacifolia From Georgia." Rhodora 52 (October 1950): 229-232.

Gray, Asa. "Augustus Fendler." In Scientific Papers of Asa Gray, 2: 465-467. Edited by Charles Sprague Sargent. Boston: Houghton, Mifflin, and Co., 1889. "Necrology: Augustus Fendler." Botanical Gazette 9 (July 1884): 111-112.

- "Notes of a Botanical Excursion to the Mountains of North Carolina, etc., with Some Remarks on the 
Botany of the Higher Alleghany Mountains, (in a letter to Sir William J. Hooker.)" American Journal of Science and Arts, 1 st ser. 42

(October-December 1841): 1-49.

- [Notice of the Death of Charles Wilkins Short.] American Journal of Science and Arts, 2d ser. 35 (May 1863): 451 .

- "Reconstruction of the Order Diapensiaceae." Proceeding of the American Academy of Arts and Sciences, 2 d ser. 8 (June 1870): 243-247.

- "Review of De Candolle's Prodromus." American Journal of Science and Arts, 1st ser. 39 (April-June 1840): 168-170.

- "Charles Wilkins Short." American Journal of Science and Arts, 2d: ser. 36 (July 1863): 130-132.

- "Shortia Galacifolia Rediscovered." American Journal of Science and Arts, 3d ser. 16

(July-December 1878): $483-485$.

- "Shortia Torr. and Gray, and Schizocodon, Sieb. and Zucc., Identical." American Journal of Science and Arts, 2d ser. 45 (May 1868): 402-403.

Greenley, T.B. "Some Reminiscences in the Lives and Characters of the Old-Time Physicians of Louisville." American Practitioner and News 35 (March 1903): $201-223$.

Gross, Samuel D. "Obituary Notice of Charles Wilkins Short, M.D." Proceedings of the American Philosophical Society 10 (November 1865): 117-186. Reprinted and repaginated as Biographical Sketch of Charles Wilkins Short, M.D. Philadelphia: Collins, 1865 .

House, Homer Doliver. "The Genus Shortia." Torreya 7 $(1907)$ : $233-235$.

Li, Hui-Lin. "Floristic Relationships between Eastern Asia and Eastern North American." Transactions of the American Philosophical Society, n.s., 42 (1952): $371-429$.

- "On the Sino-Himalayan Species of Shortia and Berneuxia." Rhodora 45 (September 1943): $333-337$.

McDowell, William A. Meeting of the Medical Faculty of Louisville. Louisville, Ky•: n.p. 1840 .

Perkins, Samuel E. III, ed. "Letters by Rafinesque to Dr. Short in the Filson Club Archives." Filson Club 
History Quarterly 12 (October 1938): 200-239. $\frac{\text { A Plea for the Louisville College. Louisville, Ky.: Morton }}{\& \text { Griswold, } 1845 \text {. }}$

Prince, Alton E. "Shortia Galacifolia in Its Type Locality." Rhodora 49 (June 1947): 159-161.

Rafinesque, C[onstantine] S. "Notice on the Myosurus

Shortii." American Journal of Science 1 (1819):

$378-380$.

Redfield, John H. "Notes of a Botanical Excursion into North Carolina." Bulletin of the Torrey Botanical Club 6 (July-August 1879): 331-339.

"Resignation of Professor Short." Western Journal of Medicine and Surgery, 3d ser. 4 (July 1849): 85-86.

Rhoades, Mary H. "Seed Germination of Shortia Galacifolia T. \& G. Under Controlled Conditions," Rhodora 68 (April-June 1966): 147-154.

Rogers, Lewis. "Facts and Reminiscences of the Medical History of Kentucky." American Practitioner 7 (April 1873): 193-222.

Ross, Malcolm N. "Seed Reproduction of Shortia Galacifolia." Journal of the New York Botanical Garden 37 (September 1936): 208-211.

Rothert, Otto A., ed. "Browsing In Our Archives, A Letter by J. Cleves Short, 1829." Filson Club History

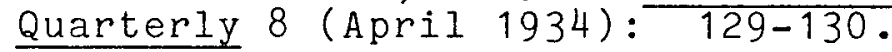

- "Browsing In Our Archives, Three Letters by Dr. L.P. Yandell, 1838." Filson Club History Quarterly 7 (July 1933): 148-153.

Sargent, C[harles] S. "Some Remarks upon a Journey of André Michaux to the High Mountains of the Carolinas in December, 1788, in a letter to Professor Asa Gray." American Journal of Science and Arts, $3 \mathrm{~d}$ ser. 32 (December 1886): $466-473$.

- "The Story of Shortia." Garden and Forest 1 (December 1888): $\frac{506-507 .}{5}$

Sargent, Ralph M. "Shortia in the Carolinas." Hemlock Arboretum 73 (1951): $1-5$.

Short, Charles Wilkins. "Alleged Causes of Milk-Sickness." Western Journal of Medicine and Surgery 1 (February 1840): 231-232. 
- "Alleged Causes of the Milk Sickness or Sick Stomach." Transylvania Journal of Medicine and the Associated Sciences 2 (February 1829): 45.

- "The Apology." Western Review and Miscellaneous Magazine 1 (December 1819): 316-317.

"Bibliographic Botanica. A Notice of Some of the More Recent Works on American Botany." Transylvania Journal of Medicine and the Associate Sciences 8 (October-December 1835): 553-574.

- Biographical Memoir of Dr. Frederick Ridgely, Late of Lexington, Kentucky." Transylvania Journal of Medicine and the Associate Sciences 3 (August 1828): 442-448.

- "A Biographical Memoir of H. Hulbert Eaton, A.M., Late Assistant Professor of Chemistry in the Medical Department of Transylvania University. Delivered November 10 th, as an introductory address to the medical class at the opening of the session of 1832-1833." Transylvania Journal of Medicine and the Associate Sciences 5 (October-December 1832): $469-481$.

- "A Brief Historical Sketch of the Origin and Progress of Cholera Asphyxia." Transylvania Journal of Medicine and the Associate Sciences 11 (January-March 1838): 11-21. - "Case of Polypus Treated Successfully with Tarter Emetic." Transylvania Journal of Medicine and the Associate Sciences 1 (February 1828): 118-120.

- "Case of Spontaneous Combustion of the Human Body." Transylvania Journal of Medicine and the Associate Sciences 3 (February 1830): 143-145.

- "Description of an Indian Fort in the Neighbourhood of Lexington, Kentucky." Transactions of the American Philosophical Society, n.s. 1 (1818): 310-312.

- Duties of Medical Student During Attendance on Lectures. An Introductory Address, Delivered at the opening of the Session 1845-6, in the Medical Institute of Louisville, Nov. 3d, 1845. Louisville, Ky.: Morton \& Griswold, 1845.

- "Enigma." Western Review and Miscellaneous Magazine 1 (November 1819): 254-255.

- "Florula Lexingtoniensis, secundum florendi aetatem digestae; or a descriptive Catalogue of the 
Phaenogamous plants indigenous to this portion of Kentucky; arranged in the order of their periods of flowering." Transylvania Journal of Medicine and the Associate Sciences 1 (May 1828): 250-256; 1 (August 1828): 407-422; 1 (November 1828): 560-575; 2 (August 1829): $438-453$.

- "A Fourth Supplementary Catalogue of the Plants of Kentucky." Western Journal of Medicine and Surgery 2 (October 1840): 283-288.

- "Instructions for the Gathering and Preservation of Plants for Herbaria; in a letter to a young Botanist." Transylvania Journal of Medicine and the Associate Sciences 6 (January-March 1833): $61-74$.

- "An Introductory Address to a Course of Lectures of Materia Medica." : Transylvania Journal of

Medicine and the Associate Sciences 6

(October-December 1833): $461-474$.

- "The Louisville Medical Institute and Dr. Drake." Boston Medical and Surgical Journal 21 (November 1839): 210-211.

- "Obituary [of Clarendon Peck]." Transylvania Journal of Medicine and the Associate Sciences 10 (October-December 1837): 594-595.

- "Observations on the Botany of Illinois, more especially in reference to the Autumnal Flora of the Prairies. In a letter to Daniel Drake, M.D." Western Journal of Medicine and Surgery 3 (March 1845): 185-198.

- "On the Analogies between Animal and Vegetable Matter." Lexington Literary Journal 1 (March 1829): $217-255,287,293$.

- On the Cultivation of Certain Medicinal Plants." Transylvania Journal of Medicine and the Associate Sciences 2 (November 1829): 512-523.

- "Paralysis of the Kidneys." Transylvania Journal of Medicine and the Associate Sciences 3 (August 1830): $424-425$.

- "Prodromus Florula Lexingtoniensis, secundum florendi aetatem digestae." Transylvania Journal of Medicine and the Associate Sciences 1 (February 18?8): 92-99.

- "Remarks on the Nomenclature of Botany." Transylvania Journal of Medicine and the Associate 
Sciences 8 (January-March 1835): 70-86.

- "Review of William Darlington's Flora Cestrica."

Transylvania Journal of Medicine and the Associate

Sciences 10 (July-September 1837): 499-506.

- "A Sketch of the Progress of Botany in Western America." Transylvania Journal of Medicine and the Associate sciences 9 (April-June 1836): 324-350; reprinted in The Journal of Botany 3 (November 1840): $97-124$.

- "A Third Supplementary Catalogue of the Plants of Kentucky." Transylvania Journal of Medicine and the. Associate Sciences 10 (July-September 1837): $335-340$.

- "To Mary with a Sprig of Winter Green." The Port Folio, 3d ser. 3 (May 1814): 520 .

- "To the Editor of the Kentucky Farmer."

Kentucky Farmer 4 (April 10, 1841): 228.

- A Valedictory Address delivered in the Chapel of Transylvania University, to the Medical Graduates at the Commencement on the 12th of March, 1828." Transylvania Journal of Medicine and the Associate Sciences 1 (August 1828): 303-309.

and Eaton, H. Hulbert. "Notices of Western Botany and Conchology." Transylvania Journal of Medicine and the Associate Sciences 4 (February 1831): $69-82$.

and Peter, Robert. "A Second Supplementary Catalogue of the Plants of Kentucky." Transylvania Journal and the Associate Sciences 8 (October-December 1835): 575-582.

"A Supplementary Catalogue of the Plants of Kentucky." Transylvania Journal of Medicine and the Associate Sciences 7 (October-December 1834): 598-600.

; and Griswold, Henry A. "A Catalogue of Native Phaenogamous Plants and Ferns of Kentucky." Transylvania Journal of Medicine and the Associate Sciences 6 (July-September 1833): 490-501.

Some Account of the Faculty of the Louisville Medical Institute. Supplementary to an Anonymous Pamphlet by. the Same, Entitled "Some Account of the Institute." Louisville, Ky.: City Gazette, 1842.

"Suum Cuique," Transylvania Journal of Medicine and the 
Associate Sciences 1 (August 1828): 1-8.

Wallace, Sara Agnes. "Letters of Jane Short Wilkins." Register of the Kentucky Historical Society 51 (January 1953): 56-69.

Yande11, Lunsford Pitts, Sr. "History of the Medical Department of the University of Louisville: An Introductory Lecture, delivered Nov. 1st, 1852." Western Journal of Medicine and Surgery 11 (January 1853): 3-26.

- A Narrative of the Dissolution of the Medical Faculty of Transylvania University. Nashville: W. Hasṣell Hunt, 1837 .

Manuscripts and Archives

Bronx, New York. New York Botanical Garden Library. John Torrey Papers.

Cambridge, Massachusetts. Harvard University. Gray Herbarium Library. Asa Gray Papers.

Chapel Hill, North Carolina. The University of North Carolina. The University of North Carolina Library. Southern Historical Collection. C.A. Hentz Autobiography.

Chapel Hill, North Carolina. The University of North Carolina. The University of North Carolina Library. Southern Historical Collection. Charles Wilkins Short Papers.

Cincinnati, Ohio. The Cincinnati Historical Society. Short Family Papers.

Frankfort, Kentucky. Kentucky State Archives. Christian County, Kentucky Will Book, 1823-1826, Volume D.

Frankfort, Kentucky. Kentucky State Archives. Bank of Kentucky, Hopkinsville Branch Bank, Individual Accounts Ledger, 1816-1821, 1822-1824.

Frankfort, Kentucky. Kentucky State Archives. Christian County, Kentucky, Commissioner's Book for 1819-1831.

Frankfort, Kentucky. Kentucky State Archives. Christian County, Kentucky. Deed Book H, 1817-1818.

Frankfort, Kentucky. Kentucky State Archives. Christian County, Kentucky, Will Book, 1823-1826, Volume D. 
Frankfort, Kentucky. Kentucky State Archives. Fayette County, Kentucky, Tax Lists, 1817-1839.:

Kew, United Kingdom. Royal Botanic Gardens Library and Archives. North American Letters.

Lexington, Kentucky. Transylvania University. Frances Carrick Thomas Library. Special Collections and Archives. Daniel Drake Papers.

Lexington, Kentucky. Transylvania University. Frances Carrick Thomas Library. Special Collections and Archives. William A. Leavy, "A Memoir of Lexington and Its Vicinity with Some Notice of Many Prominent Citizens and Its Institutions of Edcuation and Religion."

Lexington, Kentucky. Transylvania University. Frances Carrick Thomas Library. Special Collections and Archives. Medical Department Faculty Minutes.

Lexington, Kentucky. Transylvania University. Frances Carrick Thomas Library. Special Collections and Archives. Records of the Proceedings of the Board of Trustees.

Lexington, Kentucky . Transylvania University . Frances Carrick Thomas Library. Special Collections and Archives. Unbound Documents of Transylvania University, 1783-1851.

Lexington, Kentucky. United States District Court. Seventh Circuit Court Records, Short v. Short, 1826-1827.

Lexington, Kentucky. University of Kentucky. Margaret I. King Library. Special Collections and Archives. John Esten Cooke to Charles Wilkins Short, June 11, 1843.

Lexington, Kentucky. University of Kentucky. Margaret I. King Library. Special Collections and Archives. Emmet Field Horine Collection.

Lexington, Kentucky . University of Kentucky - Margaret I. King Library. Special Collections and Archives. Thomas Duche Mitchell Papers.

Lexington, Kentucky. University of Kentucky . Margaret I. King Library. Special Collections and Archives. Charles W. Short Memoranda, 1845.

Lexington, Kentucky. University of Kentucky . Margaret I. King Library. Special Collections and Archives. Charles Wilkins Short Papers.

Lexington, Kentucky . University of Kentucky. Margaret I. 
King Library. Special Collections and Archives. John Cleves Short to Jane Short, January 15,:1834.

Lexington, Kentucky. University of Kentucky. Margaret I. King Library. Special Collections and Archives. William Short Letters.

Lexington, Kentucky. University of Kentucky. Margaret I. King Library. Special Collections and Archives. Lunsford Pitts Yandell Letters.

Louisville, Kentucky. Filson Club. Descendants of William Short Genealogical Chart, 1931.

Louisville, Kentucky. Filson Club. Short Family File.

Louisville, Kentucky. Filson Club. Charles Wilkins Short Papers.

Louisville, Kentucky. Filson Club. Yandell Family Papers.

Louisville, Kentucky. Jefferson County. Office of the Clerk. Will of Charles Wilkins Short.

Louisville, Kentucky. Louisville Free Public Library. Theodore Stout Bell, Notes of Lectures Delivered in the Transylvania Medical Hall, 1830-1831.

Louisville, Kentucky. University of Louisville Archives. Board of Trustees Minutes.

Louisville, Kentucky. University of Louisville Archives. Louisville, Kentucky. Minutes of the Common Council.

Louisville, Kentucky. University of Louisville Archives. Percy Albert Davies Papers.

Louisville, Kentucky. University of Louisville Archives. University Personnel. Record Group 42. Faculty Personnel Records.

Louisville, Kentucky. University of Louisville Archives. College of Arts and Sciences. Record Group 20. Faculty Personnel Records.

Louisville, Kentucky. University of Louisville. Kornhauser Health Sciences Library. Elisha Metchalf Lecture Notes, 1847-1848.

Louisville, Kentucky. University of Louisville. Kornhauser Health Sciences Library. Ridgely, Henry, and Short Families Papers.

Louisville, Kentucky. University of Louisville. Kornhauser Health Sciences Library. Records of the Works 
Projects Administration's Kentucky Medical Historical Research Project.

Madison, Wisconsin. The State Historical Society of Wisconsin. Increase Allen Lapham Papers.

Philadelphia, Pennsylvania. American Philosophical Society. Charles Wilkins Short Papers.

Philadelphia, Pennsylvania. The Academy of Natural Sciences. ANSP Correspondence. Charles Wilkins Short Letters.

Philadelphia, Pennsylvania. The Academy of Natural Sciences. John Torrey Collection.

Philadelphia, Pennsylvania. University of Pennsylvania. The Charles Patterson Van Pelt Library. Special

Collections. C.W. Short Lecture Notes, 1813-15.

San Marino, California. The Huntington Library. Fields Collection. Charles Wilkins Short to Frederick Ridgely, January 1, 1815 .

San Marino, California. The Huntington Library. Rhees Collection. Charles Wilkins Short to John Torrey, March 3, 1838 .

Simpsonville, Kentucky. Short Family Papers in the Possession of Thomas A. Courtenay, M.D.

St. Louis, Missouri. Missouri Botanical Garden Archives. George Engelmann Papers.

Washington D.C. The Library of Congress. Short, Harrison, and Symmes Families Papers.

Williamsburg, Virginia. The College of William and Mary. Earl Gregg Swem Library. Manuscripts and Rare Books. William Short Papers.

Newspapers

The Cardinal, February 19, 1943.

Cincinnati Literary Gazette, March 13, 1824 .

Kentucky Gazette

Kentucky Reporter

Lexington Intelligencer

Louisville Daily Journal 
Louisville Public Advertiser

Other Primary Materials

Carpenter et al. v. Commonwelath of Pennsylvania. 15 Law. Ed. $127(1854)$.

General Statutes of North Carolina, Sec. 106-202. 12 to $106-202.19$.

Arland T. Hotchkiss Letter to Deborah Skaggs, December 7, 1982 .

Interview with Thomas A. Courtenay, M.D., October 11, 1979. Simpsonville, Kentucky.

J.R. Massey Letter to Deborah Skaggs, May 27, 1982.

Official Code of Georgia, Title 12-6-170 to 12-6-176.

\section{SECONDARY MATERIALS}

Books

Ackerknecht, Erwin H. A Short History of Medicine. New York: The Ronald Press Company, 1968; Originally published 1955 .

Anderson, John Q. Louisiana Swamp Doctor: The Life of Henry Clay Lewis. Baton Rouge: Louisiana State University Press, 1962.

Arndt, Karl J.R. George Rapp's Harmony Society, 1787-1847. Cranbury, New Jersey: Associated University Presses, Inc., 1972; originally published 1965.

Barkley, A.H. Miscellany. Lexington; Ky.; James M. Byrnes Co. , 1924 .

Bell, Whitfield L., Jr. The Colonial Physician and Other Essays. New York: Science History Publications, 1975 .

Britton, Nathaniel Lord and Brown, Addison. An Illustrated Flora of the Northern United States and Canada. 3 vols. New York: Charles Scribner's Sons, 1898.

Carson, Joseph. A History of the Medical Department of the University of Pennsylvania. Philadelphia: Lindsay and Blackiston, 1869 .

Casseday, Ben. The History of Louisville from Its Earliest 
Settlement till the Year 1852. Louisville, Ky.: Hull \& Brother, 1852 .

Clark, Thomas D. A History of Kentucky. Lexington, Ky.: The John Bradford Press, 1960.

Collins, Lewis and Collins, Richard H. History of Kentucky. 2 vols. 2nd ed. Louisville, Ky.: John P. Morton \& Co., 1924; originally published 1847 .

Corner, George W. Two Centuries of Medicine: A History of the School of Medicine, University of Pennsylvania. Philadelphia: J.B. Lippincott Co., 1965.

Cox, Henry Bartholomew. The Parisian American: Fulwar Skipwith of Virginia. Washington: Mount Vernon Publishing Co., 1964.

Daniels, George H. American Science in the Age of Jackson. New York: Columbia University Press, 1968.

, ed. Nineteenth Century American Science, A Reappraisal. Evanston: Northwestern University Press, 1972 .

Davenport, F. Garvin. Ante-Bellum Kentucky: A Social History, $1800-1860$. Oxford, Ohio: The Mississippi Valley Press, 1943 .

Duffy, John. Epidemics in Colonial America. Baton Rouge: Louisiana State University Press, 1971; originally published 1953 .

- The Healers: The Rise of the Medical Establishment. New York: McGraw Hill, 1976.

Dupree, A. Hunter. Asa Gray, 1810-1888. New York: Atheneum, 1968, originally published 1959 .

- Science in the Federal Goverment. Cambridge: The Belknap Press of Harvard University Press, 1957.

Dyer, John P. Tulane, The Biography of a University, 1834-1965. New York: Harper \& Row, 1966.

Eberson, Frederick. Early Physicians of the West: Forerunners of Modern Medicine. St. Petersburg, Fla.: Valkyrie Press, 1979.

Ellis, John H. Medicine in Kentucky. Lexington, Ky.: The University Press of Kentucky, 1977.

Ewan, Joseph. Rocky Mountain Naturalists. Denver: The University of Denver Press, 1950. 
Fox, Early Lee. The African Colonization Society, 18171840. Baltimore: The Johns Hopkins Press, 1919.

Geiser, Samuel Wood. Naturalists of the Frontier. Dallas: Southern Methodist University Press, 1948; originally published 1937 .

Gillispie, Charles Coulston, ed. Dictionary of Scientific Biography. 16 vols. New York: Charles Scribner's Sons, 1970-1980.

Graustein, Jeannette E. Thomas Nuttall, Naturalist: Explorations in America, 1808-1841. Cambridge: Harvard University Press, 1967.

Gray, Lewis Cecil. History of Agriculture in the Southern United States to 1860. 3 vols. New York: Peter Smith, 1941.

Gross, Samuel D., ed. Lives of Eminent American Physicians and Surgeons of the Nineteenth Century. Philadelphia: Lindsay \& Blackiston, 1861.

Harvard University, Gray Herbarium. Gray Herbarium Index 12 vols. Boston: G. K. Hall, $1968-1978$.

Havighurst, Walter. The Miami Years, 1809-1969. New York: G.P. Putnam's Sons, 1969 .

Healey, B.J. The Plant Hunters. New York: Charles Scribner's Sons, 1975 .

History of the Ohio Falls Cities and their Counties, 1778-1882. 2 vols. Cleveland, Ohio: L.A. Williams \& Co., 1882 .

Hooker, Joseph D. et al. Index Kewenis. 2 vols. and 14 supplements. Oxford, Great Britain: Oxford University Press, 1895-1965.

Horine, Emmet Field. Daniel Drake (1785-1852): Pioneer Physician of the Midwest. Philadelphia: University of Pennylvania Press, 1961.

- Biographical Sketch and Guide to the Writings of Charles Caldwell, M.D., (1772-1853). Brooks, Ky.: High Acres Press, 1960.

Humphrey, Harry Baker. Makers of North American Botany. New York: Ronald Press Co., 1961.

Joblin, M. Louisville Past and Present. Louisville, Ky.: John P. Morton and Co., 1875 .

Johnson, Allen et al. Dictionary of American Biography. 20 
vols. and 6 supplements to date. New York: Charles Scribner's Sons, 1928-1980.

Johnson, Rossiter, ed. The Twentieth Century Biographical Dictionary of Notable Americans. Detroit: Gale Research Co., 1968 ; originally published 1904.

Johnson, Thomas Cary, Jr. Scientific Interests in the Old South. New York: D. Appleton-Century Company, 1936.

Johnston, J. Stoddard, ed. Memorial History of Louisville from its First settlement to the year 1898. 2 vols. Chicago: American Biographical Publishing Co., 1896 .

Kaufman, Mairtin. American Medical Education: The Formative Years, 1765-1910. Westport: Greenwood Press, 1976.

Kelly, Howard Atwood. A Cyclopedia of American Medical Biography, Comprising the Lives of Eminent Deceased Physicians and Surgeons from 1610 to 1910. 2 vols. Philadelphia: W.B. Saunders Co., 1912.

- Some American Medical Botanists Commemorated in Our Botanical Nomenclature. Troy, New York: The Southworth Co., 1914.

and Burrage, Walter L. American Medical

Biographies. Baltimore: The Norman, Remington Co., 1920 .

Kentucky Writers' Project of the Works Progress

Administration. A Centennial History of the

University of Louisville. Louisville, Ky.: The University of Louisville, 1939.

Kerr, Charles, ed. History of Kentucky. 5 vols. Chicago New York: The American Historical Society, 1922.

Kett, Joseph F. The Formation of the American Medical Profession. The Role of Institutions, 1780-1860. New Haven: Yale University Press, 1968.

Kohlstedt, Sally Gregory. The Formation of the American Scientific Community: The American Association for the Advancement of Science, 1848-60. Urbana: University of Illinois Press, 1976.

Lewis, Alvin Fayette. History of Higher Education in Kentucky. Washginton, D.C.: Government Printing Office, 1899.

Lynch, Josephine Short. Short: an Early Virginia Family. Edited by Katherine B. and Herbert A. Elliott. Richmond, Virginia: Whittet and Shepperson, 1970 . 
McCormack, J[oseph] N. Some of the Medical Pioneers of Kentucky. Bowling Green, Ky.: The Kentucky State Medical Association, 1917.

McKelvey, Susan Delano. Botanical Exploration of the Trans-Mississippi West, 1790-1850. Jamica PIain, Mass.: The Arnold Arboretum of Harvard University, 1955 .

Medical Historical Research Project of the Work Projects Administration. Medicine and Its Development in Kentucky. Louisville Ky.: Standard Printing Co., 1940 .

Meisel, Max, ed. Bibliography of American Natural History: The Pioneer Century, 1769-1865. 3 vols. New York: Hafner Publishing Co., 1967; Originally published 1924-1929.

Merrill, Elmer D. Index Rafinesquianus. Jamaica Plain, Mass.: The Arnold Arboretum of Harvard University, 1949 .

Miller, Howard $S$. Dollars for Research: Science and Its Patrons in Nineteenth-Century America. Seattle: The University of Washington Press, 1970.

Niering, William A. and Olmstead, Nancy C. The Audubon Society Field Guide to North American Wildflowers. New York: Alfred A. Knopf, 1979.

Norwood, William Frederick. Medical Education in the United States before the Civil War. New York: Arno Press, 1971; originally published 1941 .

Oleson, Alexandra and Brown, Sanborn C., eds. The Pursuit of Knowledge in the Early American Repubulic. Baltimore: The Johns Hopkins University Press, 1976 .

Perrin, William Henry, ed. County of Christian, Kentucky. Chicago and Louisville, Ky.: F.A. Battey Publishing Co., 1884 .

Potter, David M. The Impending Crisis, 1848-1861. New York: Harper \& ROW, 1976.

Pusey, William Allen. Giants of Medicine in Pioneer Kentucky. New York: The Froben Press, 1938.

Ranck, George W. History of Lexington, Kentucky: Its Early Annals and Recent Progress. Cincinnati: Robert Clarke \& Co., 1872 .

Reingold, Nathan, ed. Science in Nineteenth Century 
America, A Documentary History. New York: Hill and Wang, 1964.

Rodgers, Andrew Denny, III. John Torrey: A Story of North American Botany. Princeton: Princeton University Press, 1942 .

- Noble Fellow." William Starling Sullivant. New York: G.P. Putnam's Sons, 1940 .

Rothstein, William G. American Physicians in the Nineteenth Century: from Sects to Science. Baltimore: Johns Hopkins University Press, 1972.

Rusk, Ralph Leslie. The Literature of the Middle Western Frontier. 2 vols. Westport, Conn.: Greenwood Press, 1975; originally published 1925.

Shafer, Henry Burnel1. The American Medical Profession, 1783 to 1850 . New York: AMS Press, Inc., 1968; originally published 1936 .

Shryock, Richard H. Medicine and Society in America: $1660-$ 1860. New York: New York University Press, 1960. - Medicine in America: Historical Essays. Baltimore: The Johns Hopkins Press, 1966.

Sigerist, Henry E. American Medicine. New York: W.W. Norton and CO., 1934.

Small, John Kunkel. Manual of the Southeastern Flora. New York: Published by the author, 1933.

Smallwood, William Martin. Natural History and the American Mind. New York: AMS Press, 1967; originally published 1941.

Sonne, Niels Henry. Liberal Kentucky, 1780-1828. Lexington, Ky.: University of Kentucky Press, 1968; originally published 1939:

Stafleu, Frans Antonie and Cowan, Richard S., eds. Taxonomic Literature. 3 vols. to date. Utrecht, The Netherlands: Bohn, Scheltenna \& Holkema, 1976-1981.

Staples, Charles R. The History of Pioneer Lexington, 1779-1806. Lexington, Ky.: Transylvania Press, 1939 .

Van Tassel, David D. and Hall, Michael G., eds. Science and Society in the United States. Homewook, I11.: The Dorsey Press, 1966.

Wade, Richard C. The Urban Frontier, The Rise of Western 
Cities, 1790-1830. Cambridge: Harvard University Press, 1959 .

Weiss, Harry B. Rafinesque's Kentucky Friends. Highland Park, NJ: By the Author, 1936.

Wilson, James G. and Fiske, John, eds. Appleton's Cyclopedia of American Biography. New York: D. Appleton and Co., 1891.

Wright, John D., Jr. Transylvania: Tutor to the West. Lexington, $\mathrm{Ky} .:$ Transylvania University, 1975.

Yater, George H. Two Hundred Years at the Falls of the Ohio: A History of Louisville and Jefferson County. Louisville, Ky.: The Heritage Corporation, 1979.

\section{Articles}

Anderson, John Q. "Henry Clay Lewis, Louisville Medical Institute Student, 1844-1846." Filson Club History Quarterly 32 (January 1958): $30-37$.

Baird, Nancy D. "Asiatic Cholera's First Visit to Kentucky: A Study in Panic and Fear." Filson Club History Quarterly 48 (July 1974): 228-240.

Beard, Eva. "Happy Traveler." Frontiers 19 (October 1954):

Bek, William G. "George Engelmann, Man of Science." Missouri Historical Review 23 (1929): 167-206, $427-446,517-535 ; 24(1930): 66-86$.

Boewe, Charles. "Rafinesque and Dr. Short." Filson Club History Quarterly 35 (January 1961): $28-32$.

Breeden, James 0. "States-Rights Medicine in the Old South." Bulletin of New York Academy of Medicine 52 (March-April 1976): 348-372.

Bendel, Frederick. "Historical Sketch of the Science of Botany in North America from 1635 to 1840." American Naturalist 13 (December 1879): 754-771.

Browne, Edward T., Jr. "Botany in Kentucky Since 1914." Transactions of the Kentucky Academy of Science. 25 (1964): $77-82$.

Calvert, William Jephtha. "The History of the Medical Department of Transylvania University and its Faculty." Johns Hopkins Hospital Bulletin. nos. 101-102 (August-September 1899): 1-15. 

Chapman, Ashton. "The Lost Flower." Frontiers 11 (December
1946): $38-40$.

- "The Search for the 'Lost' Shortia." Audubon Magazine 58 (May-June 1956): $113-115,127$.

Clute, W.N. "The Romance of the Oconee Bells." American Botanist 32 (April 1926): 6-68.

Cohen, I. Bernard. "Some Reflections on the State of Science in America During the Nineteenth Century."

Proceedings of the National Academy of Sciences 45 (May 1959): 666-677.

Corner, George W. "Apprenticed to Aesculapius: The American Medical Student, 1765-1965." Proceedings of the American Philosophical Society 109 (October 1965): $249-258$.

Daniels, George H. "The Process of Professionalization in American Science: The Emergent Period, 1820-1860." Isis 58 (Summer 1967): 151-166.

Davies, P.A. "Botanical History of Jefferson County, Kentucky." Kentucky Naturalist 5 (September 1950): 3-8.

- "Charles Wilkins Short, 1794-1863: Botanist and Physician. Part 1: A Biographical Sketch of Dr. Short." Filson Club History Quarterly 19 (July 1945): 131-155.

- "Charles Wilkins Short, 1794-1863: Botanist and Physician. Part II: Materials Relating to Dr. Short." Filson Club History Quartery 19

(October 1945): 208-249.

- "The Status of Floristic Studies in Kentucky." Transactions of the Kentucky Academy of Science 14 (May 1953): $49-58$.

Davis, Richard Beale. "The Abbé Correa in America, 1812-1820." Transactions of the American Philosophical Society, n.s. 4 (May 1955): 87-197.

Duffy, John. "Medical Practice in the Ante Bellum South." Journal of Southern History 25 (February 1959): $53-72$.

- "Notes and Documents: A Note on Ante Bellum Southern Nationalistm and Medical Practice." Journal of Southern History 34 (May 1968): 266-276.

Dupre, Huntley. "Transylvania University and Rafinesque, 1819-1826." Filson Club History Quarterly.35 (April 
1961): $110-121$

Dupree, A. Hunter. "What Manuscripts the Historian Wants Saved." Isis 53 (March 1962): 63-66.

- "The History of American Science--A Field Finds Itself." American Historical Review 71 (April 1966): 863-874.

Ewan, Joseph. "A Review of Richard Beale Davis, 'The Abbé Correa in America, 1812-1820.'" Rhodora 58 (January 1956): $45-49$.

- "Josiah Hale, Rafinesque's Pupil." Journal of the. Society for the Bibliography of Natural History 8 (November 1977): 235-243.

Ford, Charles E. "Botany Texts: A Survey of Their Development in American Higher Education, 1643-1906." History of Education Quarterly 4 (March 1964): 59-71.

Fox, Claire Gilbride. "Dr. Heber Chase: The Medical Student's Guide." Bulletin of the History of Medicine 42 (September-0ctober 1968): 462-469.

Greene, John C. "American Science Comes of Age, 1780-1820." Journal of American History 55 (June 1968): $22-41$.

Hendrickson, Walter B. "Museums and Natural History Societies in Louisville." Filson Club History Quarterly 36 (January 1962): 43-55.

Hoch, J. Hampton. "A Survey of the Development of Materia Medica in American Schools and Colleges of Pharmacy from 1821 to 1900." The American Journal of Pharmaceutical Education 48 (February 1948): $148-161$.

Horine, Emmet Field. "Early Medicine in the Kentucky and the Mississippi Valley: A Tribute to Daniel Drake, M.D." Journal of the History of Medicine 3 (Spring 1948): $263-278$.

- "A Collector Goes to the Race Track Bookishly Inclined." Filson Club History Quarterly 18 (October 1944): 203-223.

- "Daniel Drake and the Origin of Medical Journalism West of the Allegheny Mountains." Bulletin of the History of Medicine 27 (May-June 1953): 217-235.

Jenkins, Charles F. "Asa Gray and His Quest for Shortia Galacifolia." Arnoldia 2 (April 1942): $13-28$. 
- "Visit to Shortia Land.]" The Hemlock Arboretum 73 (January 1951): 1-5.

Jones, Russell M. "Ameican Doctors and the Parisian Medical World, 1830-1840." Bulletin to the History of Medicine 47 (January-February 1973): 40-65; (March-April 1973): 77-204.

Lamson-Scribner, F. "Southern Botanists." Bulletin of the Torrey Botanical Club 20 (August 1893): 315-334.

Lawson, Hampden C. "The Early Medical Schools of Kentucky." Bulletin of History of Medicine 24 (March-April 1950): 168-175.

Mallalieu, W.C. "History of the Falls of the Ohio." Kentucky Naturalist 2 (Spring 1947): 3-6.

- "Origins of the Univeristy of Louisville." Filson Club History Quarterly 12 (January 1938): $24-41$.

Marshall, Lynn L. "The Genesis of Grass-Roots Democracy in Kentucky." Mid-America 47 (October 1965): 269-287.

Miller, James L., Jr. "Transylvania University as the Nation Saw It." Filson Club History Quarterly 34 (October

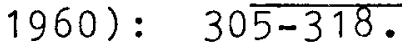

Mitchell, Martha Carolyn. "Health and the Medical Profession in the Lower South." Journal of Southern History 10 (November 1944): $424-446$.

Moorman, R.J. "Influence of Kentucky Medical Schools on Medicine." Bulletin of the History of Medicine 24 (March-April 1950): 176-186.

Norton, Elizabeth. "The Old Library of Transylvania College." Filson Club History Quarterly 1 (April 1927): $123-133$.

Numbers, Ronald L. and Numbers, Janet $S$. "Science in the Old South: A Reappraisal." Journal of Southern History 48 (May 1982): 163-184.

Oppel, Mary Cronan. "Paradise Lost: The Story of Chaumiere Des Prairies." Filson Club History Quarterly 56 (April 1982): $201-210$.

Payne, V.F. "Amos Eaton's Contribution to Kentucky, Hezekiah H. Eaton and Robert Peter." Filson Club History Quarterly 36 (April 1962): 15 1-157.

- "Thomas Duche Mitchell, 1791-1865." Filson Club 
History Quarterly 31 (October 1957): 349-357.

- "Lunsford Pitts Yandell, 1805-1878." Filson Club History Quarterly 30 (July 1956): $\quad \overline{2 \overline{32-239}}$.

Schlesinger, Arthur M., Sr. "An American Historian Looks at Science and Technology." Isis 36 (October 1946): $162-166$.

Shull, Charles A. "Fringed Bell: A New Name for Rare Shortia." Asheville (North Carolina) CitizenTimes, March 26, 1950, p. 18.

Stuckey, Ronald L. "Scientific Contributions of Amos Eaton's Son, Hezekiah Hulbert Eaton." Bartonia no. $45, " 1976-1977$, pp. 37-48.

- "The First Public Auction of an American

Herberia, Including an Account of the Fate of the Baldwin, Collins, and Rafinesque Herbaria." Taxon 20 (August 1971): 443-459.

Swem, E[arl] G. "Kentuckians at William and Mary College Before 1861, with a Sketch of the College Before that Date." Filson Club History Quarterly 23 (July 1949): $173-198$.

Titley, Joan. "Dr. Charles Wilkins Short and the Medical Journals: 1820-1831." Stechert-Hafner Book News 19 (November 1964): 29-31.

- "A Soldier Writes Home--1776, Letters from the Revolutionary War." Filson Club History Quarterly 41 (October 1967); 297-303.

Trescott, Paul B. "The Louisville and Portland Canal Company, 1825-1874." Mississippi Valley Historical Review 44 (March 1958): 686-708.

Wallace, Carolyn Andrews. "The Southern Historical Collection." American Archivist 28 (July 1965): $427-436$.

Ward, Samuel. "William Short. The Picturesque Career of the First Man Appointed to Office by President Washington." Tyler's Quarterly Historical and Genealogical Magazine 18 (January 1937): 132-140.

Wendler, Marilyn Van Voorhis. "Doctors and Diseases on the Ohio Frontier." Ohio History 89 (Spring 1980): $222-240$.

Wilson, Leonard G. "Fevers and Science in Early Nineteenth Century Medicine." Journal of the History of Medicine and Allied Sciences 33 (July 1978): 
Ahlquist, Irving Frederick. "Ohio Valley Culture as Reflected in the Short Family, 1790-1860." Ph.D. dissertation, University of Illinois, 1947.

Carstens, Nellie. "Charles Caldwell, M.D.: A Biographical Sketch." M.A. Thesis, University of Louisville, 1979 .

Deen, Arthur. "Frontier Science in Kentucky and the old Northwest, 1790-1860." Ph.D. dissertation, Indiana University, 1938 .

Jones, Elizabeth Fitzpatrick. "Henry Whitestone, Nineteenth-Century Louisville Architect," M.A. Thesis, University of Louisville, 1974.

Shackelford, George Green. "William Short, Jefferson's Adopted Son, 1758-1849." Ph.D. dissertation, University of Virginia, 1955.

Smith, Delores. "Medical Education in Kentucky: A Study of Professional Medical Education in Kentucky from 1817-1920." M.A. thesis, University of Louisville, 1976 .

Spiegel, Anna Ruth. "Public Career of James Guthrie, 1792-1869." M.A. thesis, University of Louisville, 1940 .

Other Secondary Materials

Louisville, Kentucky . Community Development Cabinet, "Louisville Survey, East Report." October, 1979.

Louisville, Kentucky. Landmarks Commission. National Register of Historic Places Nomination Form for Hayfield. April 22, 1980.

Richardson, William Allen. Descendants of William Short (Genealogy Chart). January, 1931.

Schacklette, Hansford Threlkeld. "A Preliminary Bibliography of Kentucky Botany and a First Supplement." 1940, 1941. 


\section{VITA}

Deborah Susan Skaggs was born on August 30,1949 , in Williamson, West Virginia, where she attended first grade until her family moved to Louisville, Kentucky, in December, 1955. She completed elementary and high school in Jefferson County, Kențucky, schools and was graduated from Western High School in the spring of 1967. In 1967-1968 she attended Georgetown College in Georgetown, Kentucky, and in the summer of 1968 enrolled at the University of Louisville, where she received a B.A. degree in history in December, 1970. From 1971 to 1973 she taught in the Jefferson County Public Schools and since 1975 has been a archivist at the University of Louisville. She received an M.A. in history in December, 1982. 